Claudio Roberto Cernea

\title{
VALIDADE DA IDENTIFICAÇÃO DO RAMO EXTERNO DO NERVO LARÍNGEO SUPERIOR DURANTE A REALIZAÇÃO DE TIREOIDECTOMIAS
}

Tese de doutorado apresentada à Faculdade de Medicina da Universidade de São Paulo. Área de Clínica Cirúrgica.

Orientador: Prof. Dr. Alberto Rossetti Ferraz. 
FICHA CATALOGRÁFICA

Preparada pela Biblioteca da

Faculdade de Medicina da Universidade de São Paulo

Cernea, Claudio Roberto

Validade da identificaçāo do ramo externo do nervo laríngeo superior durante a realização de tireoidectomias / Claudio Roberto Cernea. -- Sāo Paulo, 1991.

Tese (doutorado)--Faculdade de Medicina da Universida-

de de Säo Paulo. Departamento de Cirurgia.

Ârea de concentraçäo: Clínica Cirúrgica.

Orientador: Alberto Rossetti Ferraz.

Descritores: 1.TIREOIDECTOMIA/métodos 2.TIREOIDECTOMIA/efeitos adversos 3.NERVOS LARÍNGEOS/1esöes 4.ELETRO MIOGRAFIA/métodos 5.FONAÇÃO 6.NERVOS IARINGEOS/anatomiā \& histologia

USP/FM-B-9-91 


\section{DEDICATÓRIA}

A meus queridos pais, RENÉE (in memoriam) e SACHE CERNEA, que, com o seu exemplo de carinho, amor, dedicação e retidão moral, contribuíram para construir os alicerces de minhas idéias e de meus princípios.

À minha adorada esposa SELMA, que, através de sua infinita paciência, de seu inegável bom senso e, acima de tudo, de seu sublime amor, sempre me estimulou a melhorar mais e mais, como profissional, como cidadão e, principalmente, como ser humano. 


\section{AGRADECIMENTOS}

Ao Prof. Dr. ALBERTO ROSSETTI FERRAZ, meu orientador não só nesta Tese como também em boa parte de minha trajetória profissional até o presente momento, responsável direto pela minha escolha quanto à especialidade cirúrgica que ora professo e pelo meu aperfeiçoamento em outros Centros especializados; pelos seus comentários, sempre precisos e esclarecedores, pelo seu apoio e confiança em mim depositados e pela sua amizade, sincera e leal, a minha eterna gratidão.

Ao Prof. Dr. PAULO AUGUSTO DE LIMA PONTES, pela sua inestimável colaboração, ao colocar à minha disposição a sofisticada aparelhagem existente em seu consultório particular, sem a qual a avaliação objetiva da voz que foi executada neste estudo seria virtualmente impossivel.

Ao Prof. Dr. JOSÉ FURLANI, pela sua gentileza não só ao ceder o eletromiógrafo existente em seu Departamento de Anatomia como também ao participar ativamente da realização das avaliaçōes eletromiográficas pós-operatórias, sem as quais o reconhecimento das lesões nervosas
aqui analisadas seria infactível.

À Dra. SONIA MONTEIRO, fonoaudióloga, cujas avaliações e mensurações das características vocais de cada paciente foram obtidas às custas de muita dedicação e muito desprendimento, e constituiram uma das pedras angulares do presente estudo.

À Dra. LOURDES APARECIDA MARQUES, que, autorizada pelos Profs. Drs. RICARDO RENZO BRENTANI e HUMBERTO TORLONI, lançou mão dos sofisticados recursos existentes no Instituto Ludwig de Pesquisa Sobre o Câncer para efetuar a complicada análise estatística dos dados desta Tese.

Ao Prof. Dr. RUY GERALDO BEVILACQUA, pelas sugestōes, sempre bem colocadas e pelas críticas, sempre construtivas, além da complementação da análise estatística deste estu-
do.

Aos meus colegas e amigos da Disciplina de Cirurgia de Cabeça e Pescoço do Hospital das Clínicas da Faculdade de Medicina da Universidade de São Paulo: Prof. Dr. ANÓI CASTRO CORDEIRO e Drs. LENINE GARCIA BRANDÃO, GILBERTO DE BRITTO E SILVA FILHO, LUIZ ROBERTO MEDINA DOS SANTOS, MARCOS ROBERTO TAVARES E VERGILIUS JOSÉ DE ARAÚJO FURTADO FILHO, pelas sugestões para o aprimoramento deste trabalho, sempre procedentes e contrutivas, além da paciência para cobrir-me em minhas atividades rotineiras das quais, inevitavelmente, tive que me ausentar, por força não só da elaboração direta desta tese, como também do atendimento aos diversos cursos de pós-graduação.

À Dra. SUNAO NISHIO, pela sua dedicação e amizade infindáveis e sinceras e pela sua inestimável colaboração nas dissecções anatômicas e na confecção de figuras e esquemas da mais alta qualidade artística, com um refinamento visual digno dos mais aclamados mestres das artes plás-
ticas.

Aos Drs. FLÁVIO CARNEIRO HOJAIJ e AUGUSTO DUTRA JÚNIOR, pelo seu incansável auxílio na difícil e enfadonha tarefa da pesquisa bibliográfica desta tese, no que foram, aliás, muito bem assessorados pela Sra. ANNELISE CARNEIRO DA CUNHA e Srta. VALÉRIA LOMBARDI, a quem também estendo a minha sincera gratidão. 
cirúrgica.

Ao Dr. MILTON NAKAIE, responsável pelos primeiros passos na minha formação

Ao Dr. RONALD H. SPIRO, que, além de influir sobremaneira no meu aperfeiçoamento como Cirurgião de Cabeça e Pescoço, possibilitou-me a obtenção dos neuro-estimuladores, cujo papel foi fundamental na parte operacional deste estudo.

Às enfermeiras ESTERLINA WATANABE e SANDRA ARONE, que foram responsáveis pela esterilização, com óxido de etileno, dos eletrodos utilizados nos estudos eletromiográficos.

Ao Sr. LUIZ CARLOS MODESTO e À Sra. BEATRIZ VALENTIM BARBOZA, pela sua assessoria e pela minha iniciação nos meandros da informática, além de proporcionar uma diagramação e uma impresșão gráficas de soberba qualidade.

Aos Médicos-Residentes que estagiaram na Discipina de Cirurgia de Cabeça e Pescoço durante a realização deste estudo e que colaboraram de forma decisiva não só durante a execução da cirurgia em si como também ao ministrarem os necessários cuidados pré e pós-operatórios aos nossos doentes.

À Dra. KARIN C. G. BAENA, que, com a sua competente tradução do alemão para o nosso idioma pátrio, propiciou-me o acesso a alguns textos de suma importância para a revisão da literatura desta tese.

Não poderíamos esquecer os pacientes que colaboraram para que esta tese se tornasse possível e que são, em última análise, a razão primeira de nossas carreiras profissionais, pois todos nós almejamos, ao nos aprimorarmos, oferecer-lhes um cuidado médico cada vez mais competente e eficaz. Da mesma forma, não podem ser olvidados os indivíduos que, após falecerem, doaram involuntariamente seus corpos para que a etapa das dissecções anatômicas desta tese fosse cumprida. A eles, a nossa respeitosa homenagem.

Finalmente, gostaria de agradecer àqueles que tenham contribuído para a feitura desta tese e que, por alguma infeliz omissão de minha parte, não foram aqui lembrados. 


\section{ÍNDICE}

1. Introdução $\ldots \ldots \ldots \ldots \ldots \ldots \ldots \ldots \ldots \ldots . \ldots \ldots \ldots$

2. Literatura

2.1. Aspectos anatômicos ........................... 3

2.2. Aspectos fisiológicos

2.2.1. Fisiologia do nervo laríngeo superior . . . . . . . . . . . pg. 6

2.2.2. Fisiologia do músculo crico-tireoídeo ............ pg. 7

2.2.3. Fisiologia da voz ....................... pg. 8

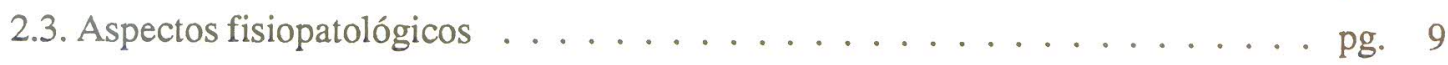

2.4. Eletromiografia da laringe ......................... 11

2.5. Técnica e complicações das tireoidectomias . . . . . . . . . . . . pg. 14

2.6. Outras causas de lesão do ramo externo do nervo laríngeo superior . . . . . . pg. 20

2.7. Reabilitação das paralisias laríngeas ... . . . . . . . . . . . pg. 21

2.8. Identificação intra-operatória do nervo recorrente . . . . . . . . . . . . pg. 22

2.9. Identificação intra-operatória do ramo externo do nervo laríngeo superior . . . pg. 23

3. Casuística e métodos

3.1. Dissecções anatômicas . . . . . . . . . . . . . . . pg. 25

3.2. Estudo clínico

3.2.1. Avaliação pré-operatória . . . . . . . . . . . . . pg. 28

3.2.2. Grupos clínicos . . . . . . . . . . . . . . . . . pg. 31

3.2.3. Técnica cirúrgica . . . . . . . . . . . . . . pg. 32

3.2.4. Avaliação pós-operatória precoce . . . . . . . . . . . . . pg. 42

3.2.5. Avaliação pós-operatória tardia . . . . . . . . . . . . pg. 45

3.2.6. Análise estatística e edição . . . . . . . . . . . . . pg. 45

3.2.7. Critérios de exclusão e formação definitiva dos grupos ... . . . . pg. 45

4. Resultados

4.1. Resultados obtidos à avaliação fonoaudiológica pré-operatória . . . . . . . . pg. 47

4.2. Resultados obtidos à avaliação fonoaudiológica pós-operatória imediata . . . . pg. 47

4.3. Resultados obtidos à avaliação eletromiográfica pós-operatória precoce . . . . pg. 50

4.4. Resultados obtidos à avaliação fonoaudiológica pós-operatória tardia . . . . . . . pg. 51 
4.5. Resultados obtidos à avaliação eletromiográfica pós-operatória tardia . . . . . pg. 53

4.6. Comparação entre os resultados obtidos com a avaliação eletromiográfica

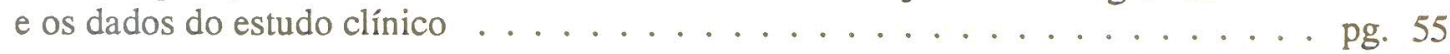

4.7. Comparação entre os resultados obtidos com as avaliações fonoaudiológica e eletromiográfica ................................... 55

5. Discussão . . . . . . . . . . . . . . . . . . . pg. 57

6. Conclusões e inferências . . . . . . . . . . . . . . . . . . 68

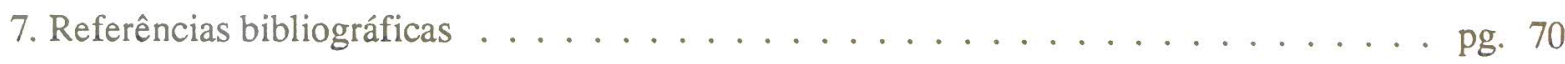

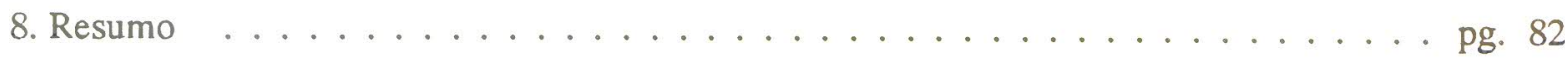

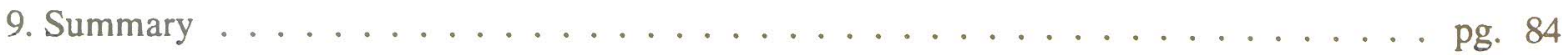

10.Apêndice 1. Protocolos de estudo

10.1. Protocolo de estudo anatômico

10.2. Protocolo de estudo clínico

11.Apêndice 2. Dados referentes aos casos clínicos 


\section{INTRODUÇÃO}

As intervenções cirúrgicas sobre a glândula tireóide são, em sua maioria, procedimentos padronizados que sofreram poucas modificações em relação à técnica descrita por KOCHER ( apud $\mathrm{EDIS}^{36}$ ) em fins do século passado. Quando realizadas por cirurgiões especializados, estas operações apresentam morbidade bastante reduzida. As principais complicações referidas na literatura, além daquelas comuns a todas as intervenções cirúrgicas (hematomas, infecções, etc.), são as lesões das glândulas paratireóides e do nervo laríngeo inferior. Já que estas duas últimas são de fácil constatação (a primeira, pelo quadro clínico decorrente da hipocalcemia; a segunda, pela intensa disfonia, se unilateral, ou até mesmo insuficiência respiratória obstrutiva, se bilateral), as suas ocorrências nas diversas casuísticas publicadas tem sido documentadas de forma inequívoca.

Entretanto, uma outra complicação pode acontecer durante a abordagem cirúrgica da glândula tireóide: é a lesão do ramo externo do nervo laríngeo superior (RELS), quando da dissecção, secção e ligadura dos ramos dos vasos tireoideanos superiores. O efeito imediato é uma paralisia do músculo crico-tireoídeo (MCT) ipsilateral, causando uma diminuição na tensão da corda vocal e impossibilitando a emissão dos sons mais agudos, principalmente em indivíduos do sexo feminino. A sua ocorrência, porém, é de difícil verificação, visto que as alterações vocais são discretas e podem passar desapercebidas (a não ser em profissionais da voz). Além disso, a laringoscopia indireta pósoperatória é práticamente normal, ou apresenta modificações muito sutis, pois a mobilidade das pregas vocais se encontra preservada.

Apesar da importância deste nervo já haver sido reconhecida há várias décadas, muito pouco se tem publicado não só sobre a real incidência da sua lesão em tireoidectomias como também sobre qual a melhor forma de se prevenir esta iatrogenia. Como veremos a seguir, a quase totalidade das escassas publicações disponíveis sobre as lesões do RELS e sua prevenção são retrospectivas. Nos poucos estudos prospectivos, a metodologia empregada é passível de críticas, dificultando o estabelecimento de conclusões mais embasadas. 
Assim, através do presente estudo, prospectivo, duplo-cego e randomizado, almejamos atingir o seguinte objetivo:

Analisar o real benefício oferecido pela identificação intra-operatória do RELS antes de se efetuar a secção e ligadura do pedículo superior da glândula tireóide, no tocante à profilaxia da sua lesão iatrogênica durante as tireoidectomias em que tal tática é impositiva. 


\section{LITERATURA}

\subsection{ASPECTOS ANATÔMICOS}

A literatura internacional sempre foi pródiga em publicações versando sobre a anatomia cirúrgica do nervo laríngeo inferior, que foi, inclusive, motivo de uma tese de Doutorado, em nosso meio, por ROSA ${ }^{133}$, em 1961. Analogamente, vários autores, tais como PEMBERTON \& BEAVER $^{124}$, em 1932, PICHLER \& GISEL ${ }^{126}$, em 1957, STEWART e col. ${ }^{143}$, em 1972, WIJETILA$\mathrm{KA}^{159}$, em 1978, SANDERS e col. ${ }^{136}$, em 1983, FRIEDMAN e col. ${ }^{54}$ e KATZ ${ }^{85}$, em 1986 e HENRY e col. ${ }^{64}$, em 1988, descreveram variações anatômicas de importância cirúrgica deste nervo, tais como ramificações extra-laríngeas e trajeto não recorrente.

Muito pouco, todavia, tem surgido, ao longo dos anos, sobre a anatomia cirúrgica do RELS, bem como sobre as suas variações anatômicas.

Já em 1892, FORT ${ }^{51}$ definia, com bastante propriedade, as características anatômicas do MCT, incluindo a sua inervação motora, fornecida pelo RELS, por ele denominado de nervo laríngeo externo.

Em 1929, FOWLER \& HANSON ${ }^{52}$ estudaram os nervos laríngeos em 200 cadáveres, com ênfase para as relações anatômicas do nervo laríngeo inferior. Afírmaram, porém, que, devido à estreita proximidade do RELS com os vasos tireoideanos superiores, a sua lesão iatrogênica durante uma tireoidectomia deveria ser bastante freqüente, apesar de os autores não haverem conseguido encontrar, àquela época, qualquer referência na literatura sobre o assunto. Concluíram que o verdadeiro papel funcional do RELS deveria ser investigado, a fim de se determinar se a sua lesão não seria, na realidade, a responsável por vários casos de disfonias pós-tireoidectomias.

BERLIN \& LAHEY ${ }^{13}$, neste mesmo ano, chamaram a atenção para algumas relações importantes entre os nervos laríngeos inferior e superior e os pedículos vasculares tireoideanos, atra- 
vés de um estudo anatômico efetuado em 22 cadáveres, sugerindo a existência de um ramúsculo, oriundo do nervo laríngeo superior, que contribuiria para a inervação do músculo inter-aritenoídeo.

Em 1930, NORDLAND ${ }^{121}$ efetuou um detalhado estudo das relações anatômicas dos nervos laríngeos superior e inferior em 31 cadáveres. Ele concluiu que havia uma possibilidade real de lesão inadvertida do RELS durante a ligadura do pedículo tireoideano superior no decurso de uma tireoidectomia.

Num excelente artigo de revisão sobre a anatomia da laringe, LORÉ ${ }^{104}$, em 1933, confirmou a existência do ramúsculo supracitado, que considerou como provindo do ramo interno do nervo laríngeo superior. Enfatizou, assim, que toda a inervação motora dos músculos intrínsecos da laringe era fornecida pelo nervo laríngeo inferior, com duas exceções: o músculo inter-aritenoídeo, que receberia uma inervação motora suplementar pelo ramúsculo supracitado, e o MCT, inervado pelo RELS.

Em 1938, GIMIGLIANO-ARGENTINO ${ }^{58}$ publicou um estudo sobre as relações anátomo-cirúrgicas do nervo laríngeo superior, objetivando fornecer diretrizes para a execução segura da sua secção cirúrgica, em casos de nevralgias de difícil controle.

Motivado pela crescente importância anátomo-cirúrgica que começava a ser atribuída ao RELS, VERNETTI ${ }^{155}$, em 1947, analisou a sua relação anatômica com o pedículo vascular superior da glândula tireóide em 30 cadáveres. Concluiu que o ramo nervoso, apesar de sua localização muito próxima ao pedículo, fletia-se medialmente entre 1 e $2 \mathrm{~cm}$ acima do polo superior da glândula tireóide, quando este possuía dimensões normais. Quando, porém, o lobo tireoideano se encontrava aumentado, com elevação do polo superior, constatou uma deformação dos vasos tíreoideanos superiores, juntando-os sobremaneira ao nervo. Outro aspecto interessante deste estudo anatômico foi a verificação de que os vasos tireoideanos superiores e o RELS se encontravam sempre envolvidos num mesmo compartimento fascial,delimitado por um folheto da cápsula cirúrgica da glândula tireóide.

Em 1948, BARROS, Filho ${ }^{10}$ apresentou, como tese para concurso de Livre-Docência nesta Faculdade, um elegante estudo anatômico realizado em 30 cadáveres: 9 frescos e 21 conservados em formol. Efetuou uma análise muito minuciosa de algumas particularidades anatômicas do RELS, tais como: verificação da existência de relação anatômica entre a face interna do lobo tíreoideano e a terminação do RELS; o ponto preciso de penetração do RELS no MCT ou no músculo constritor inferior da faringe; a distância acima ou abaixo do plano horizontal passando pelo polo glandular em que o RELS se fletia medialmente, abandonando o pedículo superior da glândula; a origem do RELS, ou seja, o ponto de bifurcação do nervo laríngeo superior. Algumas de suas conclusões são de grande importância: a) em 8 casos (13\%), o RELS se insinuava entre os ramos da artéria tireoídeana superior ou os contornava externamente; b) em 11 dissecções (18\%), a flexão medial do RELS se fazia abaixo do polo superior da glândula tireóide, a uma distância média de $8 \mathrm{~mm}$; ) ao dissecar, de forma romba, o espaço compreendido entre a face interna do polo superior tireoideano e a laringe, verificou que o RELS ficava sempre contido no mesmo folheto aponeurótico que os ramos do pedículo superior tireoideano; d) constatou que em 46 ocasiōes (77\%) o RELS penetrava inicialmente no músculo constritor inferior da faringe, adentrando diretamente o MCT nas outras 14 (23\%); mais importante, no entanto, foi a observação que em 34 situações (57\%) a porção terminal do RELS se encontrava em contato direto com o polo superior da glândula tireóide. A conclusão final do autor, 
fazendo uma correlação anátomo-cirúrgica, foi que o RELS se achava altamente exposto ao risco de ser lesado no decorrer das tireoidectomias.

CLADER e col. ${ }^{25}$, em 1957, dissecaram, em 48 cadáveres, os pedículos vasculares tireoidanos, com especial atenção para a sua topografia em relação aos nervos laríngeos. No tocante à posição do RELS, concluíram que, devido à sua proximidade com o pedículo superior da glândula tireóide, o nervo se encontraria em situação de alto risco de lesão iatrogênica durante uma tireoidectomia em $68 \%$ dos casos, fora de qualquer possibilidade de lesão em $12 \%$ e, em $20 \%$, com um risco discutível.

DURHAM \& HARRISON ${ }^{35}$, em 1964, avaliaram as relações anatômicas do RELS com o pedículo superior da glândula tireóide em 50 cadáveres, observando que o nervo cruzava obliquamente os vasos, passando de uma situação póstero-lateral para uma ântero-medial em 74\% das dissecções. Entretanto, em 7 situações(7\%), o RELS passava por entre os ramos da artéria tireoídea superior. Além dessa perigosa relação anatômica, os autores constataram, em outros $18 \%$ dos espécimes, uma situação paralela do RELS à referida artéria por um percurso de vários milímetros de sua porção mais distal, logo antes de emitir as suas ramificações.

Em 1968, MOOSMAN \& DE WEESE ${ }^{113}$ efetuaram um extenso e detalhado estudo anatômico em 200 cadáveres. Eles definiram o triângulo esternotireoídeo-laríngeo, delimitado: medialmente, pelo músculo constritor inferior da faringe e pelo MCT; anteriormente, pelo músculo esterno-tireoídeo; lateralmente, pelo polo superior da glândula tireóide. O RELS localizar-se-ia usualmente dentro dos limites deste espaço triangular, medialmente aos vasos tireoideanos superiores. Constataram um trajeto intra-muscular (dentro do músculo constritor inferior da faringe) em $11 \%$ dos espécimes. Mais importante, contudo, foi o achado de outras aberrações em $21 \%$ das situações: em $15 \%$, o RELS se encontrava intimamente aderido à porção terminal da artéria tireoídea superior ou ao seu ramo medial; em $6 \%$, o nervo se localizava entre os ramos vasculares mais terminais ou os circundava externamente, abaixo do limite mais cranial do polo superior tireoideano. Os autores consideraram estas configurações anatômicas, especialmente os últimos $6 \%$, como perigosas no tocante ao risco potencial de lesão inadvertida do nervo durante tireoidectomias.

VISSET e col. ${ }^{156}$, em 1975, identificaram o RELS em 24 espécimes obtidos a partir de 15 cadáveres. Em 16\%, constataram uma aderência do nervo à porção terminal da artéria tireoídea superior.

MENASCHE e col. ${ }^{112}$, em 1976, dissecaram o RELS em 25 autópsias consecutivas. Observaram que o diâmetro do nervo se situava entre 0,5 e 1,0 mm em $88 \%$ das peças. Em 19 caSos(76\%), o RELS se situava acima do polo superior da glândula tireóide. Nos restantes seis (24\%), o nervo se encontrava intimamente aderido à glândula. Dentre estes últimos indivíduos, três apresentavam bócios.

Neste mesmo ano, DROULIAS e col. ${ }^{34}$ clampearam o pedículo superior tireoideano logo acima do polo superior da glândula em 24 cadáveres, bem adjacente ao mesmo, e constataram a inclusão do RELS entre os ramos da pinça esmagadora em todas as 48 situações.

THOMASSIN ${ }^{145}$, em 1982, publicou um bom artigo de revisão sobre a anatomia do nervo laríngeo superior, destacando alguns aspectos embriológicos e morfológicos de seus dois ramos. 
Também neste ano, SOW e col. ${ }^{142}$ estudaram o RELS em 15 cadáveres. Observaram que o seu diâmetro se situava entre 0,8 e 1,0 mm em 80\% dos espécimes. Em 12 situações (40\%), encontraram variações anatômicas: em uma (3\%), o nervo circundava lateralmente o ramo externo da artéria tireoídea superior; nas outras 11 (37\%), passava por entre os ramos terminais da artéria.

Em 1984, KAMBIC e col. ${ }^{81}$ executaram um estudo anatômico do nervo laríngeo superior em 40 cadáveres, dirigindo a atenção principalmente para a sua origem, a qual constataram localizar-se invariavelmente no gânglio nodoso. Observaram que a divisão em dois ramos ocorria, em média, $1,5 \mathrm{~cm}$ abaixo do gânglio. Caracterizaram o RELS como tendo, em média, $8 \mathrm{~cm}$ de comprimento e $0,2 \mathrm{~mm}$ de diâmetro.

LANG e col. ${ }^{96}$, em 1987, efetuaram medidas das dimensóes e características do RELS em 44 espécimes obtidos de 22 cadáveres. Concluíram que, em média, o seu comprimento era de $8,9 \mathrm{~cm}$ e emitia 8 ramúsculos para o MCT.

ESPINOZA e col. ${ }^{40}$, em 1989, estudaram 30 RELS em 15 cadáveres, procurando reproduzir, na dissecção, as condições de uma tireoidectomia. Concluíram que, em 15\% das situações, teria ocorrido uma lesão iatrogênica do nervo, devido às suas variações anatômicas.

Num magnífico estudo anatômico feito em 25 cadáveres, LENNQUIST e col. ${ }^{101}$, em 1989, relataram 41 (82\%) RELS localizados medialmente aos vasos tireoideanos superiores, que provavelmente seriam dissecados com bastante segurança durante uma eventual tireoidectomia. Nas outras nove situações (18\%), no entanto, o nervo contornava a artéria tireoídea superior ou os seus ramos lateralmente, correndo sério risco de com eles ser ligado inadvertidamente. Por outro lado, os autores verificaram que apenas $80 \%$ dos RELS seriam passíveis de identificação intra-operatória durante uma tireoidectomia, visto que os outros $20 \%$ apresentavam um trajeto localizado entre as fibras do músculo constritor inferior da faringe.

\subsection{ASPECTOS FISIOLÓGICOS}

\subsubsection{FISIOLOGIA DO NERVO LARÍNGEO SUPERIOR}

REGULES ${ }^{129}$, em 1935, após revisar de forma abrangente a lieratura disponível sobre a fisiologia da laringe, avaliou, num elegante estudo experimental em cães, os aspectos relacionados à sua inervação. Entre as suas conclusões, observou que a ação do RELS consistia em promover a contração do MCT ipsilateral.

Neste mesmo ano, JOHNSON ${ }^{79}$ aventou a existência de uma terceira função do nervo laríngeo superior, a ser adicionada à sensitiva do seu ramo interno e à motora do seu ramo externo: estimular a produção de muco traqueal. O autor chegou a esta conclusão após um estudo experimental em gatos e sugeriu que a lesão iatrogênica do nervo durante oprerações sobre a glândula tireóide poderia interferir com a produção de muco na traquéia.

FISCHER ${ }^{50}$, em 1952, observou que a estimulação elétrica do RELS em cães produzia alongamento, aumento na tensão e discreta adução da corda vocal correspondente. 
LAM \& OGURA ${ }^{95}$, em 1954, ao analisarem a zona de projeção no sistema nervoso central da porção sensitiva do nervo laríngeo superior em gatos, concluíram pela sua localização na formação reticular dorsal da medula. Não fizeram, porém, qualquer referência, à porção motora do nervo.

$\mathrm{JESCHEK}^{78}$, numa revisão publicada em 1956, relatou que a secção do RELS diminuía a tensão da corda vocal correspondente, sem, no entanto, reduzir a sua mobilidade.

SUZUKI \& KIRCHNER ${ }^{144}$, em 1968, demonstraram que o RELS era, de fato, um nervo misto, e não puramente motor, como se acreditava até então. Ao analisar a distribuição das fibras deste nervo em gatos, concluíram que um significativo contingente delas conduzia impulsos sensitivos de uma parte da mucosa da região sub-glótica, das articulações crico-tireoídeas e do próprio MCT.

Em 1989, DOMEIJ e col. ${ }^{33}$, num elegante estudo experimental utilizando microscopia óptica e eletrônica para avaliar aspectos funcionais das fibras do nervo laríngeo superior em ratos, confirmaram os achados de SUZUKI \& KIRCHNER ${ }^{144}$.

\subsubsection{FISIOLOGIA DO MCT}

TSCHIASSNY ${ }^{150}$, em 1944, apresentou um excelente trabalho sobre a ação do MCT. Segundo ele, VESALIUS, em 1545, foi o primeiro a descrever com precisão a estrutura do músculo em duas partes, individualizadas tanto sob o aspecto morfológico como sob o funcional. Posteriormente, vários estudiosos caracterizaram estas duas unidades morfo-funcionais como pars reta e pars obliqua. Após uma extensa revisão bibliográfica, o autor relatou os resultados dos seus experimentos em 12 cães, que foram os seguintes: a) a estimulação dos MCTs aproximava o anel da cartilagem cricóide à cartilagem tireóide, sendo a primeira a estrutura que, de fato, se movimentava; b) a estimulação de apenas um dos MCTs tinha como efeito a elevação e o desvio do anel cricoídeo em direção ao lado estimulado; c) após a remoção cirúrgica da pars recta, a estimulação da porção remanescente causava uma movimentação da cartilagem cricóide no plano horizontal, em direção ao lado estimulado; inversamente, ao se ressecar a pars obliqua, a estimulação da parte restante apenas elevava a referida cartilagem; d) ao se estimularem os MCTs, as cordas vocais se alongavam e os processos vocais se aproximavam; e) em alguns animais, foram constatados movimentos espontâneos do anel cricóide, geralmente sincronizados com a respiração.

Em 1950, KATSUKI ${ }^{84}$ analisou a função dos músculos fonatórios em 24 indivíduos. Concluiu que o músculo vocal e o MCT atuavam de forma coordenada para regular a intensidade e a freqüência da voz. Quando esta era baixa, apenas o primeiro músculo agia, modulando a emissão da voz juntamente com a intensidade do fluxo aéreo respiratório. Entretanto, em freqüências mais altas, havia, superajuntado ao aumento de tensão efetuado pelo músculo vocal, um verdadeiro esticamento da prega vocal, ocasionado pela contração do MCT. Esta somatória de açõões musculares, contudo, atingia um limite de altura tonal próprio para cada indivíduo, acima do qual a voz incorria em "falsetto". O autor também observou que o músculo vocal contraía de forma isométrica, ao passo que o MCT o fazia de forma isotônica.

FREEDMAN ${ }^{53}$, em 1956, fez um estudo experimental em cães, nos quais, após secção bilateral dos nervos recorrentes, desinseria os MCTs das cartilagens cricóide e tireóide, observan- 
do uma diminuição da tensão e uma abdução das pregas vocais. O autor sugeriu o emprego deste método em doentes portadores de paralisia bilateral dos nervos laríngeos inferiores.

Em 1961, ARNOLD ${ }^{5}$ publicou um dos estudos mais completos e minuciosos disponíveis na literatura mundial sobre a fisiologia e patologia do MCT. Segundo ele, a cartilagem tireóide estaria fixada aos ossos hióide e esterno pela musculatura pré-tireoídea. Assim sendo, a contração do MCT promoveria uma elevação da cartilagem cricóide, indo de encontro à cartilagem tireóide. Postulou que o MCT seria o responsável pelo que chamou de aumento da "tensão externa" da prega vocal, ao passo que o músculo vocal causaria um incremento na "tensão interna" (mais refinada). Quanto aos aspectos morfo-funcionais, defendia o autor a existência de uma terceira porção do MCT, a pars interna, que possuiria uma ação de fechamento da glote.

Além da evidente função fonatória do MCT, vários autores, tais como HORIUCHI \& SASAKI $^{73}$, em 1978, MATHEW e col. ${ }^{110}$, em 1988, WOODSON e col. ${ }^{162}$ e WOODSON ${ }^{163}$, em 1989, demonstraram neste músculo uma atividade funcional durante a respiração, mormente expiratória, através de estudos experimentais em cães. WOODSON ${ }^{164}$, em 1990, confirmou estes achados, observando um aumento da atividade muscular durante a expiração em seres humanos.

\subsubsection{FISIOLOGIA DA VOZ}

No estudo já mencionado, ARNOLD 5 , em 1961, fez também uma soberba revisão sobre os aspectos fisiológicos da voz. No que concerne à influência da musculatura intrínseca da laringe e, mais especificamente, do MCT, sobre a fonação, alguns aspectos interessantes foram elucidados. Na realidade, a elevação da freqüência vocal seria determinada por três fatores: a) o aumento da tensão da prega vocal pelo MCT; b) a forma da prega, conferida pelo músculo tireo-aritenoídeo; c) o mecanismo vibratório, ditado pela configuração da glote. De fato, a contração do MCT visando aumentar a tensão e o comprimento da corda vocal seria contrabalançada pela atividade de outros músculos (como, por exemplo, o crico-faríngeo, que tenderia a encurtar a corda vocal), num sensível e delicado mecanismo de modulação. A atuação maior do MCT ocorreria apenas em freqüências vocais mais altas, mais intensamente durante o canto.

Em outro trabalho ${ }^{6}$, datado de 1962 , o mesmo autor apresentou outras conclusões dignas de menção. Ele constatou que o posicionamento das pregas vocais para a produção de um determinado som ocorria antes da vocalização, propriamente dita, que dependia do fluxo aéreo provindo dos pulmões. Assim, a contração do MCT para a produção dos sons mais agudos ocorreria apenas com a mentalização, por parte do indivíduo, do som a ser produzido, antes da fonação. Além disso, neste estudo $\mathrm{ARNOLD}^{6}$ procurou quantificar a faixa de atuação do $\mathrm{MCT}$ em relação à frequêencia vocal. Concluiu que, numa escala variando entre 167 e 358 ciclos por segundo (cps), cantada por um indivíduo normal do sexo masculino, a atividade do MCT aumentaria de 200 a $600 \%$, com o incremento progressivo da freqüência.

Em seu tratado sobre a fisiologia da voz publicado em 1968, ZEMLIM $^{168}$ confirmou vários dos achados de ARNOLD e estabeleceu alguns conceitos de suma importância no que concerne ao mecanismo de fonação. Afirmou que a freqüência fundamental, ou seja, a freqüência vocal mais confortável para o indivíduo, situava-se ao redor de $130 \mathrm{cps}$ no sexo masculino e de $260 \mathrm{cps}$ no feminino. O autor citou a definição de registro vocal feita por GARCIA, em 1841: "sequência de sons de 
igual qualidade, numa escala variando da mais baixa à mais alta freqüência que um indivíduo conseguia emitir". Referiu-se, ainda, às duas teorias mais aceitas para explicar a produção da voz: a mioelástica-aerodinâmica e a neuro-cronaxial. Segundo a primeira, as cordas vocais vibrariam pela passagem do ar, e a freqüência dependeria do seu comprimento, em relação à sua tensão e à sua massa. Por outro lado, a segunda postulava que cada novo ciclo vibratório seria iniciado por estímulos do nervo recorrente, e a freqüência vocal dependeria do ritmo destes impulsos.

LARSON e col. ${ }^{97}$, em 1987, sugeriram, após os resultados de um estudo fisiológico em seres humanos normais, que a contração do que denominaram "unidades motoras individuais", tanto do MCT como do músculo tireo-aritenóide, interferiria na freqüência vocal fundamental do indivíduo, sempre que sua voz estivesse num registro acima do seu normal.

Em 1988, HIRANO ${ }^{68}$ apresentou uma publicação relatando a sua experiência de 20 anos de estudos sobre a fisiologia da voz, incluindo uma excelente análise em indivíduos comuns e em cantores profissionais. Basicamente, os achados supracitados de ARNOLD ${ }^{5,6}$ foram corroborados, concluindo que o MCT interfere de forma incisiva tanto na freqüência fundamental quanto na porção referente às notas agudas do registro vocal, principalmente em cantores profissionais.

LINDESTAD e col. ${ }^{102}$, em 1990, confirmaram um nítido aumento na atividade elétrica do MCT, à medida em que a freqüência vocal aumentava, em indivíduos normais.

SLAVIT e col. ${ }^{141}$, no mesmo ano, também observaram um incremento na atividade do MCT e da intensidade vibratória de praticamente toda a musculatura laríngea com o aumento da freqüência, estudando laringes caninas através da eletroglotografia.

\subsection{ASPECTOS FISIOPATOLÓGICOS}

MYGIND (apud BEYER ${ }^{16}$ ), ao rever toda a literatura existente até 1906 sobre a paralisia do MCT, foi capaz de localizar 13 casos, aos quais adicionou outros quatro, por ele observados. Neste últimos, os achados laringoscópicos foram: uma glote oblíqua, um abaulamento expiratório da corda vocal afetada em direção cranial e, inversamente, um deslocamento passivo caudal à inspiração.

Em 1918, JUDD e col. ${ }^{80}$ efetuaram um interessante estudo experimental em cães, comparando os possíveis mecanismos de lesão traumática do nervo recorrente. Concluíram que a secção e a ligadura do nervo causavam uma lesão definitiva, ao passo que o seu estiramento ou o seu pinçamento ocasionavam uma lesão apenas temporária. Não houve referência a lesões do RELS.

NEW \& CHILDREY ${ }^{120}$, em 1932, empreenderam uma análise retrospectiva de 217 casos de paralisias de corda vocal atendidos na Clínica Mayo. As causas variavam de doenças do sistema nervoso central até lesões nervosas iatrogênicas pós-tireoidectomias. Eles observaram que, quando ocorriam lesões isoladas do nervo recorrente, a corda vocal paralisada geralmente se situava ou na posição mediana (em 90\% das situações) ou na cadavérica (intermediária entre a mediana e a lateralizada). Quando, todavia, a lesão incluía também o RELS, a corda se localizava sempre na posição cadavérica. Em apenas um caso, com uma lesão arteriosclerótica do sistema nevoso central, os autores constataram uma lesão exclusiva do RELS, que se acompanhava de uma prega vocal ondulada, de superfície irregular e com perda parcial da capacidade de adução. Em casos de tireoidectomia 
para tumores benignos, constataram que $65,38 \%$ das cordas vocais se encontravam paralisadas em posição mediana e $34,62 \%$ em posição cadavérica. No entanto, após tireoidectómias realizadas para o tratamento de tumores malignos, esta proporção se invertia: $28,57 \%$ e $71,43 \%$, respectivamente. Nenhum caso de lesão iatrogênica pós-operatória isolada do RELS foi relatado.

Em 1934, LEMERE ${ }^{100}$ publicou uma revisão bastante abrangente sobre as paralisias laríngeas. Segundo ele, a posição mediana da prega vocal paralisada após lesão do nervo laríngeo inferior se devia à contração do MCT, inervado pelo RELS. Em alguns indivíduos, ocorria um relaxamento na tensão do MCT com o tempo, desviando a corda vocal para a posição cadavérica. Em outros, porém, o MCT mantinha a sua contração indefinidamente. $\mathrm{O}$ autor chegou a sugerir que, em casos de paralisia bilateral das pregas vocais com obstrução respiratória, fosse tentado um bloqueio bilateral dos RELS, com Novocaína ou mesmo álcool.

BEYER $^{16}$, em 1941, relatou um caso assaz interessante. Após uma feridá traumática penetrante da laringe, que foi prontamente suturada num hospital e cicatrizou satisfatóriamente, um doente se queixou de que não conseguia mais "chamar os porcos na sua fazenda". À laringoscopia, o autor constatou que a prega vocal do mesmo lado da lesão se achava mais alongada do que a outra, apesar de exibir mobilidade normal. Este comprimento maior da corda afetada conferia uma aparência endoscópica de que a glote se encontrava num plano oblíquo, quando este, na verdade, era horizontal. Segundo o autor, o prognóstico da recuperação da voz do paciente dependeria basicamente do tipo de lesão que ele teria sofrido: se tivesse ocorrido um dano do RELS, a perda seria, provavelmente definitiva; se, por outro lado, o trauma fosse apenas uma contusão do MCT, poder-se-ia esperar alguma recuperação da função.

Em 1948, LAWSON ${ }^{98}$ afirmava que a paralisia do RELS se acompanhava de uma correspondente flacidez da prega vocal, cuja borda ficaria ondulada. A voz resultante seria áspera e monótona, e a fadiga vocal sobreviria com facilidade.

MORAN \& CASTRO ${ }^{114}$, em 1951 relataram um procedimento altamente criticável, embora bastante esclarecedor. Ao operar a glândula tireóide em 8 indivíduos, eles intencionalmente identificaram e esmagaram, com uma pinça hemostática, o RELS, durante a dissecção do polo superior tireoideano. Em 4 casos, a manobra foi executada unilateralmente, constatando os autores uma voz rouca e monótona, que persistiu por aproximadamente 7 dias, com aparente retorno à normalidade em todos. Já nos outro 4 pacientes, ambos os nervos foram lesados; estes doentes exibiram as mesmas alterações, acrescidas de uma intensa fatigabilidade vocal. Estas alterações persistiram por vários meses em três casos, ocorrendo um restabelecimento da voz no quarto. Os autores concluíram que, apesar da lesão do RELS não se revestir da mesma gravidade que a lesão do nervo recorrente, acarretava um sensível incômodo para o paciente e uma preocupação a mais para o cirurgião, razão pela qual deveria ser evitada.

No estudo já citado de ARNOLD ${ }^{6}$, de 1962, uma análise da paralisia do RELS foi efetuada. Segundo o autor, a causa mais freqüente seria a lesão iatrogênica pós-tireoidectomia, seguida da difteria, traumatismos cervicais, vômitos violentos e doenças neurológicas centrais. Preconizava que, na pesquisa propedêutica dessa paralisia, a sensibilidade laríngea deveria sempre ser avaliada, com o fito de se descartar uma lesão associada do ramo interno do nervo laríngeo superior. No que tange aos aspectos laringoscópicos, o autor ressalvou que esta paralisia passava amiúde desapercebida, pois as alterações que causava eram sutis e inconstantes. Todavia, poderiam ocorrer: glote oblíqua, flacidez e hiperemia da prega vocal afetada e prolapso da cartilagem aritenóide ipsilateral. A 
avaliação fonaudiológica dos portadores de paralisia do MCT revelou os seguintes achados: voz mais fraca e monótona, encurtamento do tempo fônico, rebaixamento da tonalidade vocal, redução do alcance vocal e perda da capacidade de cantar, mormente em tons mais altos. Quanto ao prognóstico, destacou o autor que, ao contrário da melhora espontânea que com freqüência se observava em casos de paralisia unilateral de nervo recorrente, as consequências da paralisia do RELS eram definitivas e o comprometimento vocal, permanente.

WARD e col. ${ }^{157}$, em 1977, publicaram um interessante artigo, no qual sustentavam que a lesão iatrogênica de RELS era bastante freqüente durante a tireoidectomia, e que a sua real freqüência era subestimada. Afirmaram que a qualidade da voz se encontrava permanentemente comprometida, principalmente ao cantar. À laringoscopia indireta, nenhuma alteração era detectada durante a respiração. Entratanto, à fonação, poder-se-ia observar uma assimetria da glote, além de uma hiperemia da corda vocal afetada. O diagnóstico tornava-se ainda mais problemático quando a lesão era bilateral, conforme foi constatado pelos autores em 6 casos. Nenhum destes pacientes era capaz de controlar adequadamente a emissão da sua voz e um deles, uma moça que era uma cantora profissional, teve que encerrar prematuramente a sua carreira.

ABELSON \& TUCKER $^{1}$, em 1981, efetuaram um estudo em 4 indivíduos voluntários normais, nos quais foi feito um bloqueio anestésico do nervo laríngeo superior, seguido de um estudo eletromiográfico e de uma avaliaçào fonoaudiológica. Em todos foi constatada uma diminuição acentuada ou mesmo ausência de atividade do MCT, acompanhada de uma disfonia e incapacidade para emitir sons agudos.

Em 1988, BEVAN ${ }^{14}$ e col. afirmaram que, devido às dificuldades para se comprovar uma lesão do RELS, métodos mais modernos, tais como a videolaringoscopia e a eletromiografia deveriam ser empregados na sua prospecção.

Ainda neste ano, os mesmos autores ${ }^{15}$ relataram o uso dos dois métodos propedêuticos supracitados na avaliação de três doentes com paralisia do RELS.

\subsection{ELETROMIOGRAFIA DA LARINGE}

Indubitavelmente, a eletromiografia dos músculos intrínsecos da laringe deve ser a pedra angular de qualquer estudo que se proponha a avaliar, com critério e profundidade, as alterações na inervação motora desse importante órgão. Justifica-se, destarte, não só a abundância de publicações disponíveis na literatura internacional sobre o tema, como também o seu agrupamento num item à parte, visando facilitar a sua análise.

Em 1957, uma das maiores autoridades internacionais sobre o assunto, FAABORGANDERSEN $^{42}$, apresentou uma tese junto à Universidade de Copenhagen na qual analisava, sob o prisma eletromiográfico, a musculatura laríngea de 59 indivíduos: 32 voluntários normais, 23 portadores de paresia unilateral e 4 com paresia bilateral das cordas vocais. No que concerne ao MCT, o eletrodo era posicionado ao nível da cartilagem cricóide, $1 \mathrm{~cm}$ lateralmente à linha média. $\mathrm{O}$ tempo de latência entre o aparecimento de atividade elétrica e a fonação variou de 0,35 a 0,55 segundos. Uma outra constatação interessante foi que o traçado eletromiográfico poderia variar enormemente com uma pequena diferença de posicionamento do eletrodo dentro do músculo a ser estudado. Em indivíduos normais e no lado são dos portadores de paresia unilateral, observou um incremento na atividade 
elétrica do MCT de até $600 \%$ na emissão de sons mais agudos. Dentre os 23 indivíduos com paresia unilateral da prega vocal, em 17 ela se achava na posição mediana ou paramediana, fato este também observado nos 4 portadores de paresia bilateral. Nstas situações, a atividade elétrica do MCT se encontrava normal (nos doentes com paralisia unilateral, idêntica ao lado não afetado), ao contrário dos demais músculos intrínsecos da laringe, cuja ação se mostrava marcadamente reduzida. Em contrapartida, em 6 casos nos quais a corda parética se situava em posição cadavérica, havia perda da atividade motora do MCT, da mesma forma que o restante da musculatura intrínseca laríngea.

Ao analisar eletromiograficamente a musculatura extrínseca da laringe, FAABORG-ANDERSEN \& SONNINEN ${ }^{43}$, em 1959, concluíram que havia uma diminuição da atividade elétrica dos músculos esterno-tireoídeo e esterno-hioídeo, à medida em que sons mais agudos eram produzidos.

Em 1963, SIRIBODHI e col. ${ }^{140}$ publicaram um interessante estudo experimental em 6 cães. Em três destes animais, o RELS foi seccionado junto à sua entrada no MCT, seguindo-se uma abrupta interrupção na atividade elétrica do músculo. Contudo, alguns sinais de reinervação, tais como potenciais polifásicos, começaram a surgir no $26^{\circ}, 27^{\circ}$ e $31^{2}$ dias, respectivamente nos três cães, após a secção do nervo. Uma completa recuperação eletromiográfica foi comprovada nos 3 espécimes, no $91^{\circ}, 129^{\circ}$ e $153^{\circ}$ dias, respectivamente. Os autores justificaram os resultados obtidos com o argumento que, por se tratar de apenas um músculo suprido por somente um nervo, a reinervação, mesmo ocorrendo de forma desordenada, teria como consequência uma reabilitação funcional satisfatória. Isto, porém, não sucedeu com os outros três animais, que foram submetidos a secções do nervo recorrente. Nestes, houve tardiamente, alterações na mobilidade da prega vocal, atribuídas pelos autores a reinervações anômalas.

YANAGIHARA \& VON LEDEN ${ }^{165}$, em 1966, analisaram os aspectos eletromiográficos do MCT em 3 indivíduos normais. Ficou evidente uma aumento linear na atividade elétrica do músculo à medida em que a freqüência dos sons emitidos subia, principalmente acima de $300 \mathrm{cps}$. Por outro lado, pouca ou nenhuma alteração nesta atividade era notada quando o fluxo expiratório era incrementado. Quanto à intensidade sonora, o seu aumento se acompanhava de uma maior atividade do MCT apenas em freqüências vocais mais baixas.

HIROTO e col. ${ }^{69}$, em 1967, observaram um período de latência entre o início da atvidade eletromiográfica do MCT e o início da fonação situado entre 100 e 200 milissegundos, tempo este inferior ao anotado para os demais músculos intrínsecos da laringe. A amplitude do traçado eletromiográfico do MCT variou entre 300 e 500 microvolts.

Ainda neste ano, FAABORG-ANDERSEN e col. ${ }^{45}$ comprovaram, utilizando a eletromiografia em um homem normal, o aumento de atividade do MCT com a elevação da freqüência vocal. Por outro lado, não foi notada qualquer mudança no comportamento do músculo quando se alterava o fluxo expiratório.

HIROTO e col. ${ }^{70}$, no ano seguinte, efetuaram uma investigação eletromiográfica em 21 pacientes com paralisia unilateral de prega vocal. Constataram uma atividade elétrica normal do MCT em todos, com exceção de um caso, no qual, surpreendentemente, a prega paralisada ocupava uma posição mediana (e não intermediária, como seria de se esperar quando ambos os nervos laríngeos se encontrassem comprometidos).

HIRANO $^{67}$, em 1969, num artigo sobre a metodologia da eletromiografia da laringe, estabeleceu que o acesso ao MCT deveria ser tentado através de uma punção na borda superior da 
cartilagem cricóide, lateralmente à linha média. Ressalvou, porém, que outras maneiras havia de se atingir o músculo, desde que se utilizasse um eletrodo coaxial em forma de agulha, posicionando-o numa direção paralela ao plano lateral da cartilagem tireóide.

Em 1970, $\mathrm{DEDO}^{30}$ realizou um extraordinário estudo eletromiográfico da laringe em duas partes: uma experimental, em 33 cães e a outra em 52 doentes com paralisias ou paresias de prega vocal. Focalizando os achados pertinentes ao RELS, ele observou na primeira parte, que, à secção do nervo, apesar da pouca ou nenhuma alteração constatada na mobilidade da corda vocal, os potenciais elétricos do MCT despareciam, após um breve espasmo no momento da seç̧ão. Em outro grupo de animais, o RELS foi apenas esmagado, causando de imediato o mesmo silêncio eletromiográfico do MCT. Entretanto, o autor notou um retorno da função do músculo, comprovada à eletromiografia, 10 a 25 dias após. Na segunda parte do trabalho, foi, de início, comparada a confiabilidade de dois tipos de eletrodos para estudos em humanos, o monopolar e o bipolar, concluindo-se que, apenas para o MCT, ambos eram igualmente eficientes na avaliação da atividade elétrica. Em 4 indivíduos com história clínica de alteração da voz, a corda vocal tinha mobilidade normal, apesar de ligeiramente arqueada durante a fonação. A eletromiografia do MCT não mostrou qualquer atividade, confirmando assim a lesão do RELS. Nenhum dos pacientes apresentava rouquidão, mas sim perda da capacidade de emitir notas mais altas, principalmente ao cantar. $\mathrm{O}$ autor não foi capaz de encontrar, em nenhum dos casos, os sinais e sintomas usualmente atribuídos à disfunção do RELS, concluindo que a única forma se comprová-la efetivamente era por meio da eletromiografia do MCT.

Neste mesmo ano, KOTBY \& HAUGEN ${ }^{89}$ afirmaram ser factível a distinção, à eletromiografia, entre as lesōes próprias dos músculos laríngeos e aquelas secundárias ao comprometimento da sua inervação motora. Assim, na primeira situação observar-se-iam os chamados aspectos miopáticos: diminuição dos potenciais de ação das unidades motoras e presença freqüente de potenciais polifásicos e, ocasionalmente, de fibrilações. Por outro lado, a desnervação causaria no músculo efetor um silêncio eletromiográfico inicial, ao qual se poderia seguir uma pequena atividade elétrica residual, com potenciais de ação de amplitude mínima e monofásicos; fibrilações eram um achado mais freqüente.

Em 1973, HAGLUND e col. ${ }^{61}$ relataram três pacientes que foram submetidos à eletromiografia do MCT, por apresentarem queixa de disfonia. Constatou-se de forma inequívoca a paralisia do músculo nos três casos, sendo que em dois não se observavam alterações à laringoscopia.

Numa outra publicação deste mesmo ano, HAGLUND ${ }^{62}$ procurou estabelecer as bases técnicas para a execução do estudo eletromiográfico do MCT, através de uma análise efetuada em 17 músculos de 13 indivíduos normais. $\mathrm{O}$ acesso ao músculo era obtido mediante a inserção de um eletrodo coaxial na linha média, ao nível da borda superior da cartilagem cricóide, que era, depois, orientado em direção lateral e ligeiramente cranial; o posicionamento era repetido do outro lado, retrocedendo-se o eletrodo sem, no entanto, retirá-lo da pele. $O$ autor enfatizou que pequenas mudanças na posição do eletrodo dentro do MCT causavam grandes alterações no traçado eletromiográfico. Quanto aos resultados, observou que $77 \%$ dos potenciais registrados eram di ou trifásicos e $19 \%$ eram monofásicos. A intensidade situou-se entre 150 e 800 microvolts, sendo a média de 394. Não ocorreram complicações após a realização da eletromiografia.

Numa revisão sobre eletromiografia da laringe datada de 1988 , BEVAN e col. ${ }^{15}$ afirmaram que uma das suas mais úteis aplicações seria a detecção de lesões iatrogênicas do RELS após 
tireoidectomias. Esta opinião foi compartilhada por JANSSON e $\mathrm{col}^{77}$, num importante estudo prospectivo publicado neste mesmo ano e referido, com maiores detalhes, mais adiante.

BLAIR $^{17}$, em 1989, lamentava que, apesar das inúmeras publicações e constantes refinamentos técnicos surgidos no campo da eletromiografia da laringe, este recurso propedêutico ainda não se havia integrado de forma definitiva à prática clínica, na avaliação das paralisias laríngeas.

\subsection{TÉCNICA E COMPLICAÇÕES DAS TIREOIDECTOMIAS}

"Pode a glândula tireóide, quando aumentada, ser removida com uma razoável esperança de se salvar o paciente? A experiência, enfáticamente, responde não! ... Se um cirurgião pode ser tâo tolo para tentar isto...cada passo será envolvido por dificuldade, cada golpe de seu bisturi será seguido de uma torrente de sangue, e ele poder-se-á considerar afortunado se a sua vítima sobreviver o suficiente para lhe proporcionar a oportunidade de terminar o seu ato de açougueiro...nenhum cirurgião honesto e sensivel tentaria jamais tal empresa"

(GROSS, 1866, apud MANSBERGER ${ }^{109}$ ).

Até o fim do século passado, as abordagens cirúrgicas da glândula tireóide eram consideradas procedimentos arriscados, conforme atestavam BURNETT e col. ${ }^{22}$, ao afirmarem,em seu livro sobre cirurgia publicado em 1894: "A tireoidectomia é uma operação perigosa, principalmente por causa do risco iminente de hemorragia...os nervos recorrentes devem ser cuidadosamente evitados (não havia qualquer referência ao RELS)....a base do eventual tumor deve ser ligada em massa....a tireoidectomia total deve ser evitada sempre que possível".

O pioneiro da moderna cirurgia da glândula tireóide foi, indubitavelmente, KOCHER. Já ao final do século passado, ele havia desenvolvido e publicado os princípios técnicos que até hoje norteiam as tireoidectomias (apud EDIS $^{36}$ ). Em 1907, quando já acumulava uma experiência pessoal de 3.333 operações sobre a glândula tireóide, o autor escreveu um capítulo em seu livro ${ }^{88}$, no qual padronizava uma admirável gama de procedimentos, indo de uma simples nodulectomia (que só indicava em casos excepcionais) até a ressecção de bócios intra-torácicos, em bloco com costelas e esterno. O autor usava dois tipos de incisões: em "colar", transversal, e em ângulo reto, com um ramo superior horizontal e um descendente, vertical. O descolamento dos retalhos era feito abaixo do plano do músculo platisma e a linha média era aberta sem a secção dos músculos pré-tireoideanos. A dissecção era feita por fora da cápsula cirúrgica da glândula. Antes da ligadura dos pedículos vasculares, o autor recomendava a luxação do bócio (exceto em casos de doença de Basedow, nos quais o primeiro passo era a abordagem e ligadura dos vasos tireoideanos). Os ramos da artéria tireoídea inferior eram identificados na face lateral da glândula e ligados, após a visualização do nervo recorrente . O pedículo vascular superior era identificado e ligado próximo ao polo superior. Não se fazia menção ao RELS na descrição deste tempo operatório. A mortalidade observada por KOCHER em seus casos operados por bócios não tóxicos foi de $0,3 \%$, ao passo que, em doentes portadores de hipertireoidismo, ela se elevava para 4,5\%. Vale ressaltar que, pela relevância de sua contribuição para o desenvolvimento da cirurgia tireoideana, KOCHER recebeu o Prêmio Nobel de Medicina e Fisiologia em 1909, tendo sidó o primeiro cirurgião a ser agraciado com esta láurea, segundo MORRIS \& SCHIR$\mathrm{MER}^{115}$. 
Em 1930, NORDLAND ${ }^{121}$ chamou a atenção para o fato de que KOCHER havia, na verdade, preconizado a proteção do RELS ao procurar individualizar o pedículo superior da glândula tireóide antes de ligar os seus ramos. Por outro lado, citou uma técnica que lhe foi transmitida pelo Dr. GUSTAV SCHWYZER, sob a forma de comunicação pessoal, a qual sugeria a ligadura em massa dos polos superiores, objetivando não só proteger o RELS e a glândula paratireóide superior como também preservar uma quantidade razoável de tecido tireoideano, que, segundo SCHWYZER, era quase sempre normal nesta região da glándula.

ROEDER ${ }^{132}$, em 1931, alertou para a possibilidade concreta de lesão do RELS durante a ligadura dos vasos do polo superior tireoideano, baseando-se em sua experiência pessoal de mais de 1600 operações. Descreveu, então, uma técnica para a abordagem do referido polo, que consistia em seccionar a musculatura pré-tireoideana entre duas pinças hemostáticas e, ao abrí-las, expor amplamente o pedículo tireoideano superior, cujos ramos eram ligados separadamente, evitando-se a inclusão de qualquer estrutura que se assemelhasse ao RELS.

URBAN ${ }^{154}$, em 1934, expos as conclusōes a que chegou após efetuar 6000 tireoidectomias. Constatou uma incidência de $3,3 \%$ de paralisia das cordas vocais, que se encontravam geralmente em posição mediana, sem nenhum caso de hipoparatireoidismo. $\mathrm{O}$ autor não fez qualquer referência, contudo, a lesões do RELS.

Em 1942, MULLIGAN ${ }^{116}$ relatou a experiência acumulada num período de 5 anos no Hospital Johns Hopkins, constando de 504 tireoidectomias parciais, das quais 6,3\% exibiram no periodo pós-operatório uma paralisia uni ou bilateral das pregas vocais. Também aqui não foi feita qualquer mençÃo a lesões do RELS.

HEYD $^{65}$, em 1944, ao fazer uma revisão sobre complicações respiratórias e vocais após tireoidectomias, afirmou que de 15 a $20 \%$ dos pacientes apresentavam alterações na mobilidade das pregas vocais, dos quais 1 a $1,5 \%$ de forma definitiva. $O$ autor não especificou o tipo de alteração.

Em nosso meio, ANDRADE ${ }^{3}$, em um livro publicado em 1946, relatava uma incidência de paralisia transitória das pregas vocais de $1.4 \%$, e de paralisia definitiva de $0,14 \%$, em 700 tireoidectomias. No entanto, registrava disfonia discreta em $38 \%$ dos pacientes e acentuada em $6 \%$, no período pós-operatório imediato. Mais tardiamente, 3,1\% dos casos continuava com disfonia discreta e $1,5 \%$ acentuada. $\mathrm{O}$ autor atribuiu estas complicações ao traumatismo cirúrgico que sofriam a laringe e seus músculos, especialmente o MCT.

Em 1948, LAHEY \& HOOVER ${ }^{94}$ encontraram 1,5\% de lesōes do nervo recorrente em 3.000 tireoidectomias, sem, contudo, citar qualquer lesão do RELS.

Da mesma forma, GISSELSSON ${ }^{59}$, no ano seguinte, ao apresentar a sua experiência de 597 operações sobre a glaândula tireóide, dentre os quais destacou $2 \%$ de paralisias de corda vocal, não comentou a possibilidade de comprometimento iatrogênico do RELS.

BERENDES ${ }^{12}$, em 1954, afirmava que, além das alterações óbvias na laringe provocadas por tireoidectomias, estas poderiam também ser responsáveis por perturbações "apenas perceptíveis na função mais sublime daquele órgão, ou seja, no canto", fruto de uma lesão iatrogênica do RELS. A voz ficava mais grave e mais fraca, tornando-se monocórdica e não alcançando a altura anterior. Muito característica era a dificuldade que cantores profissionalmente treinados encontravam para acompanhar instrumentos musicais. A restauração do alcance da voz não era conseguida nunca. 
Neste mesmo ano, ZAIDMAN ${ }^{166}$, ao relatar a sua experiência em 568 tireoidectomias, dizia: "Com relação ao RELS, suponho que devemos ter causado a sua paralisia em alguns casos, muito embora tenhamos tomado as precauções para evitar o seu dano ligando sempre os ramos da artéria tireoídea superior em contato com a glândula tireóide, e nunca no seu tronco. Não podemos, porém, assegurar com certeza a freqüência de tal lesão, por não dispormos de um estudo da mobilidade das cordas vocais em todos os doentes".

ANDRADE, Sobrinho \& SAPIA ${ }^{4}$, em 1956, ao apresentarem os resultados obtidos em 143 intervenções sobre a glândula tireóide, comentavam: "O ramo interno do nervo laríngeo superior raramente é alcançado, sendo que a possibilidade de lesão do seu ramo externo é maior devido a este integrar o pedículo vásculo-nervoso tireoídeo superior e, às vezes, encontrar-se entre os ramos da artéria. Ele é sempre mobilizado com o pedículo e, quando lesado, observam-se alterações ligeiras da voz, que se torna mais grave, e pequeno grau de disfagia. Essas alteraçōes são sempre transitórias. Fazendo-se o pinçamento do pedículo superior, após o seu isolamento, bem junto ao parênquima glandular, evita-se este acidente".

GREGG $^{60}$, num artigo publicado em 1957 sobre como evitar traumatismos sobre os nervos laríngeos em tireoidectomias, afirmava que, por maior que fosse a experiência do Serviço ao qual pertencia (8.000 operações), os seus integrantes não eram capazes de, à laringoscopia indireta, diagnosticar uma eventual lesão do RELS. Por outro lado, lembrou que esta lesão era, provavelmente, mais freqüente do que se imaginava.

Em 1959, FINOCHIETTO ${ }^{49}$ alertou para a possibilidade de se incluir o RELS inadvertidamente numa ligadura vascular não só ao nível do pedículo superior como também na dissecção do lobo piramidal, quando este porventura se encontrasse muito próximo à porção superior do MCT.

$\mathrm{HUNT}^{74}$, em 1961, enfatizava a necessidade de se ligarem individualmente os ramos do pedículo tireoideano superior, pois, ao se incluir tecido glandular na ligadura, poder-se-ia traumatizar o RELS. Achava, entretanto, muito difícil a tentativa de se identificar este nervo durante este tempo cirúrgico, ao contrário da visualização do nervo recorrente, que julgava obrigatória quando se dissecava a face lateral da glândula tireóide.

Neste mesmo ano, DESAI ${ }^{32}$ afirmava que a lesão iatrogênica do RELS era freqüente após tireoidectomias feitas por cirurgiões pouco cuidadosos, e com freqüência os seus efeitos eram atribuídos à intubação endotraqueal realizada pelo anestesista.

PERZIK $^{125}$, em 1963, apresentou 124 doentes submetidos à tireoidectomia total, dos quais 5,6\% tiveram paralisia do nervo recorrente no período pós-operatório. Não foi feita qualquer referência ao RELS.

Num artigo de revisão datado de 1964, KIRCHNER $^{87}$ dizia da dificuldade de se identificar alterações sutis na movimentação da prega vocal, como aquelas causadas pela lesão do RELS. Sugeria, como profilaxia desta complicação, a ligadura dos vasos do polo superior tireoideano indivudualmente, o mais próximo possível da glândula.

Em 1968, ZAVALETA e col. ${ }^{167}$ descreviam a injeção de $10 \mathrm{ml}$ de novocaína no espaço compreendido entre o polo superior tireoideano e a laringe, com o fito de facilitar a sua liberação e a laqueadura dos vasos tireoideanos superiores. Diziam os autores que a ligadura do tronco da artéria tireoídea superior deveria ser evitada, pelo risco de lesão do RELS que acarretava. As alterações vocais que a ela se seguiam, contudo, foram qualificadas de temporárias. 
REYNIER \& LAURIAN ${ }^{131}$, em 1973, enfatizaram a necessidade de se dissecar com delicadeza o pedículo superior tireoideano não apenas em lobectomias totais como também nas subtotais, visando a preservar a integridade do RELS.

BRITTO E SILVA, Filho e col. ${ }^{20}$, em 1975, também defendiam a dissecção cuidadosa, seguida de ligadura individualizada dos ramos dos vasos tireoideanos superiores, com o intuito de se evitar a lesão iatrogênica do RELS, que traria como consequência u'a modificação no timbre vocal.

Em 1977, LORÉ, Jr. e col. ${ }^{105}$ não julgavam necessária a visualização do RELS ao dissecar o polo superior da glândula tireóide, visto que, em 111 lobectomias totais nas quais este nervo foi colocado em risco, puderam constatar apenas um caso em que a corda vocal se encontrava arqueada e a paciente se queixava de dificuldade para cantar.

CORDEIRO27, em 1979, afirmava: "Entre as lesões dos nervos estão incluídas as mais comuns e lamentáveis das complicações pós-tireoidectomia. Sua freqüência real só pode ser aquilatada pelo sistemático exame endoscópico do laringe. Sua incidência é maior após operações bilaterais, após operaçòes por bócio difuso tóxico, em reoperações, e em tratamento de câncer tireóideo".

Neste mesmo ano, EDIS $^{36}$ considerava que a lesão do RELS era muito discutida e poucas vezes comprovada, já que as alterações vocais que causava eram sutis e poderiam não ser notadas, a não ser que o indivíduo fosse um cantor profissional ou um locutor público. Porisso, a real freqüência desta complicação após tireoidectomias continuava desconhecida. $\mathrm{O}$ autor sugeria que esta lesão poderia ser evitada se a ligadura dos vasos do polo superior tireoideano só fosse executada após a secção do istmo e mobilização do lobo.

Ainda em 1979, FARENZENA e col. ${ }^{46}$, em Porto Alegre, relataram um estudo retrospectivo no qual 54 pacientes que haviam sido submetidos à tireoidectomia foram investigados, pesquisando-se uma alteração da voz através de entrevistas. Dentre eles, 24 (46,2\%) queixavam-se de disfonias. Ao submeter estes indivíduos à laringoscopia indireta, os autores constataram 12 casos $(23,1 \%)$ em que a glote se mostrava oblíqua, considerando-os como portadores de paralisia iatrogênica do RELS. Não havia qualquer menção ao tempo transcorrido entre as cirurgias e as avaliações vocais. A maioria dos indivíduos era portadora de bócio colóide.

Ainda em 1979, WATT-BOOLSEN e col. ${ }^{158}$ avaliaram a influência da tireoidectomia sobre a performance vocal de 20 doentes, dos quais 12 possuíam bócios simples e 8 , bócios tóxicos. Todos eles tinham uma voz pior do que o normal antes da cirurgia. No período pós-operatório, 9 (75\%) dentre os portadores de bócios simples experimentaram uma melhora da voz, sem, contudo, atingir os parâmetros de normalidade. Nos indivíduos com bócios tóxicos, ao invés, não foi notada qualquer melhora na fonação.

No mesmo ano, FERRAZ \& TOLEDO ${ }^{47}$, ao detalhar os cuidados técnicos que deveriam ser estritamente observados, estribados numa experiência de 4.860 tireoidectomias, reenfatizavam que a ligadura dos ramos vasculares tireoideanos superiores deveria sempre ser efetuada rente ao parênquima tireoideano, para se evitar lesão do RELS.

HOCKAUF \& SAILER ${ }^{71}$, em 1980 , encontraram $147(8,6 \%)$ casos de paralisia unilateral e $22(1,3 \%)$ de paralisia bilateral do nervo recorrente em 1713 pacientes submetidos à tireoidectomia. Nenhuma referência a lesões do RELS foi feita. 
Neste mesmo ano, CAROSI e col. ${ }^{24}$ diziam que não se devia olvidar o RELS no decurso de uma tireoidectomia, pois a sua lesão, amiúde menosprezada, determinaria uma alteração do timbre vocal, acompanhada de um "cansaço da voz" durante o seu uso prolongado.

Ao analisar 378 doentes tireoidectomizados (dos quais 230 submetidos a procedimentos bilaterais), PAINEAU e col. ${ }^{123}$, em 1983, encontraram 11 (1,9\%) casos de lesões dos nervos laríngeos, diagnosticados por laringoscopia indireta: $8(1,3 \%)$ do nervo recorrente e $3(0,6 \%)$ do RELS. Como a laringoscopia só foi indicada quando aparecia uma disfonia no período pós-operatório, os autores admitiram que os números apresentados podiam situar-se abaixo da real freqüência de comprometimento destes nervos.

Em 1984, KARLAN e col. ${ }^{83}$ publicaram a sua experiência pessoal com 1.000 tireoidectomias, nas quais não observaram nenhum caso de lesão definitiva do nervo recorrente. Afirmaram, outrossim, que a documentação de uma lesão do RELS era muito difícil, por exigir o exame através de um laringoscópio para se detectar o abaulamento da prega vocal. Os autores planejavam submeter os seus doentes a uma avaliação cine-radiológica, além da já referida laringoscopia, visando a determinar a real incidência de comprometimento do RELS.

Ainda neste ano, KARK e col. ${ }^{82}$ relataram que a mais famosa pessoa a apresentar uma lesão pós-tireoidectomia do RELS foi, talvez, a soprano Amelita Galli-Curci, razão pela qual alguns autores associaram o seu sobrenome a este ramo nervoso. Durante 15 anos, ela havia notado o lento crescimento de um bócio, até que, em 1935, sob anestesia local, foi submetida à excisão cirúrgica de um bócio pesando 170 gramas, com cuidadosa identificação e preservação de ambos os nervos recorrentes. Entretanto, após a cirurgia o seu registro vocal caiu dramaticamente e a sua voz ficou permanentemente rouca. $\mathrm{Na}$ época, a crítica especializada escreveu: “...a sua voz surpreendente se foi para sempre; em lugar da maciez aveludada, restou apenas o triste espectro de um fantasma".

CLOUSE \& FLYNN²6, em 1985, destacavam, num artigo de revisão, que, apesar de ambos os ramos do nervo laríngeo superior serem, em teoria, passíveis de lesão iatrogênica durante a disecção do polo superior tireoideano, o RELS tinha, na prática, maior chance de ser lesado, em virtude da sua proximidade com o pedículo superior. Além disso, realçavam a importância do profundo conhecimento anatômico que qualquer profissional disposto a executar uma tireoidectomia deveria ter para prevenir a ocorrência de uma lesão iatrogênica de qualquer um dos nervos laríngeos, com as suas consequentes implicações médico-legais.

No mesmo ano, ZUCKERMANN \& KUHN ${ }^{170}$ analisaram a sua experiência de 463 tireoidectomias, notando uma incidência de $1(1,16 \%)$ paralisia de nervo recorrente em 86 doentes submetidos a tireoidectomias sub-totais e totais; nenhum caso de paralisia foi identificado dentre os 377 procedimentos parciais. Não houve referência a lesōes do RELS.

Em 1987, LEKACOS e col. ${ }^{99}$ publicaram um estudo prospectivo e randomizado sobre lesões do RELS . Foram operados 281 indivíduos: em 54, foi realizada uma ligadura alta "clássica" da artéria tireóidea superior; nos outros 227, os ramos arteriais tireoideanos superiores foram ligados individualmente. Utitlizando apenas uma avaliaçào subjetiva da voz e uma laringoscopia indireta para a avaliação pós-operatória, os autores encontraram $3(5,5 \%)$ casos de lesão do RELS no primeiro grupo e nenhum no segundo, diferença esta estatisticamente significativa. 
SHAHA \& JAFFE ${ }^{138}$, em 1988, estudaram as complicações ocorridas em 200 tireoidectomias consecutivas executadas por residentes. Constataram, usando somente a laringoscopia indireta, um $(0,5 \%)$ caso de lesão do RELS e um $(0,5 \%)$ de lesão do nervo recorrente.

Num minucioso trabalho, também publicado em 1988, JANSSON e col..$^{77}$ analisaram prospectivamente 20 doentes submetidos à tireoidectomia por cirurgiões gerais. Foram empregados, tanto no período pré como no pós-operatório, uma avaliaçào fonoaudiológica completa, com medidas objetivas da freqüência vocal fundamental e em sons agudos, além de uma eletromiografia do MCT e de uma laringoscopia indireta. 12 (58\%) doentes exibiram uma paresia do MCT no período pós-operatório, dos quais 3 eram os que já mostravam esta deficiência antes, agravada após a operação. Curiosamente, em um dos pacientes a lesão do RELS ocorreu no lado oposto ao do lobo tireoideano operado, e os autores atribuíram-na à dissecção do istmo tireoideano, que se estendia até o outro lado. Segundo os autores, o método propedêutico que detectou a lesão do RELS com mais precisão foi a eletromiografia do MCT.

TOVI e col. ${ }^{148}$, em 1989, comunicaram a sua experiência de 100 tireoidectomias totais consecutivas. Na descrição da técnica, destacaram a necessidade de ligadura individualizada dos ramos vasculares do polo superior tireoidano, para se evitar a lesão do RELS. Observaram lesões do nervo recorrente, intencionais por razões oncológicas, em 2 (2\%) casos, um dos quais, surpreendentemente, recuperou a mobilidade da prega vocal após 16 meses. Os autores não notaram lesão do RELS em nenhuma ocasião, utilizando apenas a laringoscopia indireta pós-operatória.

Neste mesmo ano, WILLIAMS e col. ${ }^{160}$ compararam as alterações da função laríngea verificadas em 11 doentes submetidos à tireoidectomia com 14 indivíduos que sofreram outros tipos de operação, de duraçào semelhante. Nenhuma alteração funcional de importância na laringe foi observada no grupo controle. Entre os pacientes tireoidectomizados, porém, 4 (36\%) apresentaram paresia do nervo recorrente, com evidentes alterações fonatórias. Outros dois doentes ficaram muito disfônicos após a cirurgia, apesar de exibirem mobilidade normal das pregas vocais à laringoscopia indireta; nestes dois casos, foi aventada uma possível lesão do RELS.

Ainda em 1989, FERRAZ \& BRANDÃO 48 observaram 2,4\% de paralisias da prega vocal em 4.683 pacientes submetidos a tireoidectomias por bócios simples. Analogamente, BRANDÃO \& FERRAZ ${ }^{19}$, neste mesmo ano, notaram uma incidência de $1,8 \%$ da mesma complicação em 920 tireoidectomias efetuadas para bócios tóxicos. Não foi feita referência a lesōes do RELS nesta casuística.

AUGUSTE \& ATTIE $^{8}$, em 1990, estudaram 80 doentes, inicialmente submetidos a uma lobectomia tireoideana com diagnóstico de biópsia de congelação intra-operatório inconclusivo ou benigno, e que foram reoperados para a complementação da tireoidectomia total, em virtude do achado, no exame histo-patológico definitivo, de carcinoma. Quando o diagnóstico definitivo foi obtido precocemente, o que ocorreu em 39 casos, o intervalo médio entre as duas intervençōes foi de 3,5 dias. Nos restantes 41 pacientes, este intervalo se situou ao redor de 130 dias, em média, provavelmente por um atraso na confirmação da malignidade. Treze doentes sofreram, durante as reoperações, esvaziamentos ganglionares cervicais modificados. Os autores verificaram, no período pós-operatório, o aparecimento de hipoparatireoidismo transitório em 10 (12,5\%) pacientes e de paralisia temporária do nervo recorrente em 2 (2,5\%). Não houve qualquer complicação definitiva, não se tecendo qualquer comentário quanto a eventuais lesões do RELS. Os autores concluíram que as reoperações efetuadas sobre a glândula tireóide eram procedimentos seguros, desde que realizados antes de sete 
dias ou mais de quatro meses após a cirurgia inicial e obedecendo a uma técnica meticulosa, com identificação e preservação das glândulas paratireóides e dos nervos recorrentes e, de preferência, feitas por um cirurgião com experiência em cirurgia tireoideana.

\subsection{OUTRAS CAUSAS DE LESÃO DO RELS}

Como já tivemos oportunidade de analisar, NEW \& CHILDREY ${ }^{120}$, em 1932, bem como ARNOLD ${ }^{6}$, em 1962, relataram várias possíveis causas de lesão do RELS, que iam da difteria até doenças neurológicas.

FAABORG-ANDERSEN \& JENSEN ${ }^{44}$, em 1963, num artigo sobre paralisia unilateral do nervo laríngeo superior, relataram dois casos em que a causa deste déficit era uma neuropatia periférica.

EVANS e col. ${ }^{41}$, em 1982, ao avaliarem prospectivamente 116 doentes submetidos a 128 endarterectomias carotídeas, encontraram uma incidência de $1,5 \%$ de lesões dos nervos laríngeos (sem especificar qual) no período pós-operatório.

No ano seguinte, DEHN \& TAYLOR ${ }^{31}$ observaram, em 40 pacientes que sofreram a mesma cirurgia citada no trabalho anterior, $16(40 \%)$ casos de disfonia importante, dos quais 5 (13\%) exibiam as cordas vocais móveis à laringoscopia indireta.

Em 1985, CAVO,Jr. ${ }^{23}$ aventou a possibilidade da intubação orotraqueal ser a causadora de paralisia de corda vocal, e efetuou um elegante estudo anatômico dos possíveis locais de compressão do nervo recorrente pela sonda. $\mathrm{O}$ autor encontrou, relatados na literatura, 32 casos de paralisia vocal com esta etiologia. Nenhuma referência, porém, foi feita ao RELS.

ALDOORI \& BAIRD 2 , em 1988, analisaram prospectivamente 52 doentes submetidos a endarterectomias carotídeas, identificando intraoperatoriamente o nervo vago em todos os indivíduos, o nervo recorrente em $3(5,8 \%)$ ocasiões e o RELS também em $3(5,8 \%)$ casos. Os autores constataram disfonia importante em $10(19,2 \%)$ pacientes, dos quais $3(5,8 \%)$ apresentavam paralisia da prega vocal. Todos os doentes apresentaram uma recuperação completa da sua voz, inclusive nos 3 com paralisias da prega vocal, cuja mobilidade retornou ao normal.

ROSENBERG e col. ${ }^{134}$, em 1989, observaram alterações degenerativas importantes no ramo interno do nervo laríngeo superior em ratos idosos, extrapolando os seus achados para tentar explicar algumas disfunções da laringe humana próprias da senilidade.

Neste mesmo ano, HARTMAN e col. ${ }^{63}$ relataram um caso de uma mulher de 35 anos que desenvolveu crises intermitentes de paresia do RELS, desencadeadas por traumas psicológicos, que persistiam por até um mes. Rotularam este quadro de disfonia psicogênica.

Em 1990, THOMPSON e col. ${ }^{147}$ publicaram um estudo de 4 portadores de Síndrome de Reye (uma grave encefalopatia aguda, mais encontradiça em crianças) que apresentavam, como sequela, paralisia de prega vocal associada à anestesia da glote, indicativas de uma lesão de ambos os nervos laríngeos.

Ainda neste ano, BECKFORD e col. ${ }^{11}$ analisaram as alterações vocais em 10 doentes submetidos à intubação orotraqueal para a anestesia geral em cirurgias ginecológicas e compararam- 
nos com 10 indivíduos normais. Apesar de observarem uma discreta disfonia em vários casos intubados, os autores não foram capazes de demonstrar objetivamente qualquer comprometimento da função laríngea nestes doentes. Outrossim, atribuíram estas disfonias a possíveis alterações ventilatórias ou cerebrais.

Uma causa insólita de paralisia vocal que, infelizmente, pode mostrar uma tendência a aumentar nos dias de hoje, foi descrita por HILLSTROM e col. ${ }^{66}$, em 1990: a auto-injeção de drogas na veia jugular interna por toxicômanos. Além do extravasanento da substância injetada, causando um considerável dano tissular local, havia o aparecimento freqüente de graves infecções locais, causadas pela falta de antissepsia. Os autores analisaram 9 casos de viciados em drogas com paralisias vocais uni ou bilaterais definitivas.

\subsection{REABILITAÇÃO DAS PARALISIAS LARÍNGEAS}

Há uma infinidade de publicações na literatura internacional sobre este tema. Contudo, todas se ocupam exclusivamente do tratamento das lesões do nervo recorrente ou das paralisias laríngeas completas, estas geralmente de etiologia neurológica.

Pela sua simplicidade, a simples anastomose término-terminal do nervo recorrente seccionado deve ser tentada, assim que for descoberta ainda durante a tireoidectomia. Os seus resultados, entretanto, como foi demonstrado por CRUMLEY29 num artigo de revisão publicado em 1990, deixam muito a desejar.

Já em 1944, HOLINGER ${ }^{72}$ discutia, num artigo de revisão, as opções terapêuticas disponíveis na época para a medialização ou lateralização da prega vocal paralisada, de acordo com a sua posição.

Um dos métodos mais difundidos tem sido a injeção de material inerte, mormente teflon, na prega vocal afetada, com o intuito de medializá-la. Defenderam esta técnica, especialmente em paralisias unilaterais: TUCKER152 (1980), HYBELS75 (1980), THOMÉ146 (1989) e PONTES \& ARRAIS127 (1989). ESCAJADILLO39 (1988) preconizava o reposicionamento da corda vocal com um implante de silicone. Já TRAPP e col.149 (1989) e REMACLE e col.130 (1989) utilizaram a injeção de colágeno na prega vocal, para colocá-la em posição mais medial.

Outra modalidade terapêutica bastante utilizada, principalmente nas paralisias bilaterais nas quais as pregas se encontrassem em posição mediana, tem sido a aritenoidectomia, segundo BOFENKAMP $^{18}(1966)$, SINGER e col. ${ }^{139}(1985)$ e SAMPAIO $^{135}(1989)$, modificada por vários autores e evoluindo para a miectomia dos aritenoídeos, desenvolvida em nosso meio por PONTES ${ }^{127}$ (1989). NARCY e col. ${ }^{117}$, em 1990, defenderam a aritenoideopexia em crianças portadoras de paralisias laríngeas.

Desde a descrição da técnica de reinervação laríngea por TUCKER ${ }^{151}$ (1976), inúmeros autores relataram a sua experiência com esta forma de reparação, tais como: MAY e col. ${ }^{111}$ (1980), TUCKER ${ }^{152}$ (1980), HYBELS ${ }^{75}$ (1980), NEAL e col. ${ }^{118}$ (1983), CRUMLEY e col. ${ }^{28}$ (1988), ATTALI e col. ${ }^{7}$ (1988), MANIGLIA e col. ${ }^{107}$ (1989), MANIGLIA e col. ${ }^{108}$ (1989), TUCKER ${ }^{153}$ (1989), BALDISSERA e col. ${ }^{9}$ (1989) e JACOBS e col. ${ }^{76}$ (1990). 
Outros métodos, como a lateralização da prega vocal, descrita por EJNELL e col. ${ }^{37}$ (1984), a laringoplastia, preconizada por MAHIEU \& $\operatorname{SCHUTTE}^{106}$ (1989) e o reposicionamento da prega vocal com um expansor intra-laríngeo, defendida por KURILOFF e col. ${ }^{93}$ (1990), tem surgido.

NETTERVILLE e col. ${ }^{119}$,em 1990, efetuaram uma excelente revisão sobre estes métodos de reabilitação das paralisias laríngeas, com uma análise crítica de suas vantagens e desvantagens.

Finalmente, são dignas de nota algumas publicações que postularam o emprego de mecanismos, por vezes muito engenhosos, de estimulação elétrica ou eletrônica da laringe paralisada: OTTO e col. ${ }^{122}$ (1985), KRAUS e col. ${ }^{92}$ (1987), BRONIATOWSKII ${ }^{21}$ (1988), SANDERS e col. ${ }^{137}$ (1989) e KOJIMA e col. ${ }^{86}$ (1990).

\subsection{IDENTIFICAÇÃO INTRA-OPERATÓRIA DO NERVO RECORRENTE}

É interessante notar a criatividade de alguns dos autores abaixo citados, quando defenderam seus métodos para a identificação intra-operatória do nervo recorrente. Fica patente, porém, a complexidade destes métodos quando cotejada com aqueles que objetivavam individualizar o RELS, como veremos mais adiante. Este contraste foi, aliás, o único motivo pelo qual este sub-item foi inserido.

Em 1973, KRATZ ${ }^{90}$ propos a identificação intra-operatória dos nervos laríngeos superior e inferior com um estimulador elétrico de $3 \mathrm{~V}$. A contração do MCT, resultante do estímulo do RELS, era verificada no próóprio campo operatório. A movimentação das pregas vocais, ao invés, era avaliada por uma microlaringoscopia de suspensão intra-operatória.

Em 1978, este mesmo autor ${ }^{91}$ propos a introdução de um broncofibroscópio pela boca do paciente durante uma tireoidectomia, posicionando-o ao nível da glote. Assim, ao estimular eletricamente o nervo recorrente, movimentos da corda vocal correspondente seriam detectados.

Já WOLTERING e col. ${ }^{161}$, em 1984, advogavam a intubação do doente com uma sonda endotraqueal provida de dois balōes. Enquanto o balão inferior possibilitaria a ventilação por pressão positiva e evitaria a aspiração de secreções, o superior seria posicionado ao nível das pregas vocais e funcionaria, acoplado a um manômetro eletrônico, na detecção de movimentos destas pregas, quando o nervo recorrente fosse estimulado no campo da tireoidectomia.

Por outro lado, GAVILÁN \& GAVILÁN ${ }^{57}$, em 1986, sugeriam a simples colocação de um dedo na região do músculo crico-aritenoídeo posterior pelo próprio campo da tireoidectomia, a fim de sentir a sua contração durante a estimulação elétrica do nervo recorrente. Os autores empregaram o método em 80 indivíduos, obtendo êxito na identificação do nervo em todos.

No ano seguinte, ZINI \& GANDOLFI ${ }^{169}$ utilizaram uma técnica semelhante à de WOLTERING e col., com a diferença de que conectavam o sensor pneumático a um alarme sonoro, que disparava sempre que a prega vocal se movia, fruto da eletro-estimulação do nervo recorrente.

Em 1988, LIPTON e col. ${ }^{103}$ defendiam a colocação por via endoscópica, durante a tireoidectomia, de eletrodos nos músculos intrínsecos da laringe. Em seguida, executavam o que denominaram "monitorização eletrofisiológica", ou seja, analisavam a resposta eletromiográfica dos referidos músculos à estimulação elétrica do nervo recorrente. 
Como KRATZ ${ }^{90}$, PREMACHANDRA e col. ${ }^{128}$, em 1990, consideravam útil a visualização intra-operatória da glote com um fibroscópio durante a dissecção e eletro-estimulaçào do nervo recorrente, com a diferença que conectavam o aparelho a um monitor de vídeo, efetuando destarte uma videolaringoscopia direta simultânea à tireoidectomia.

\subsection{IDENTIFICAÇÃO INTRA-OPERATÓRIA DO RELS}

ELNER e $\operatorname{col}^{38}{ }^{38}$,em 1968, julgavam de grande importância a identificação do RELS antes de se efetuar qualquer ligadura no polo superior tireoideano (apesar de não entrarem em detalhes quanto à forma como esta identificação era feita).

Provavelmente, KRATZ ${ }^{90}$, em seu estudo datado de 1973 e já citado, foi o primeiro a sugerir, de forma objetiva, a identificação intra-operatória do RELS durante a dissecção do polo superior tireoideano, como profilaxia da sua lesão iatrogênica. Como vimos, o autor utilizava um neuroestimulador e observava o efeito desejado, ou seja, a contraçào do MCT, no próprio campo da tireoidectomia.

Em 1984, KARK e col. ${ }^{82}$ publicaram um interessante estudo, composto basicamente de uma parte retrospectiva e outra prospectiva. Na primeira, eles analisaram 325 doentes que haviam sido submetidos a tireoidectomias, encontrando uma incidência de $28 \%$ de alterações vocais, sendo $7 \%$ disfonias importantes. Na segunda parte, os autores efetuaram a identificação do RELS, apenas pelo seu aspecto anatômico, em 38 indivíduos, durante a execução de uma tireoidectomia. Dos 56 nervos procurados (algumas operaçòes foram bilaterais), 47 (84\%) foram identificados e preservados. Utilizando apenas uma avaliação vocal com um medidor de freqüência muito preciso, os autores detectaram alterações em 9 (25\%) pacientes, que foram definitivas em apenas $2(6 \%)$. Ao compararem estes dados com um grupo controle prospectivo, composto por 100 doentes submetidos à intubação endotraqueal para cirurgias ginecológicas, observaram alterações vocais definitivas e importantes em $3 \%$.

FRIEDMAN \& TORIUMI ${ }^{55}$, em 1986, demonstraram, de forma detalhada, a maneira pela qual identificavam rotineiramente o RELS no decorrer de uma tireoidectomia. Assim, após executar todos os passos da tireoidectomia concernentes à dissecção do polo inferior e da face lateral do lobo tireoideano (incluindo a visualizaçào sistemática do nervo recorrente e das glândulas paratireóides), os autores só ligavam os ramos do pedículo vascular superior tireoideano após uma identificação do RELS no seu ponto de entrada no MCT, por meio de um neuro-estimulador.

Num estudo que já foi mencionado, LENNQUIST e col. ${ }^{101}$, em 1987, preconizavam a dissecçào do pedículo superior da glândula tireóide visando a identificar, apenas pelas suas características anatômicas, o RELS. Além disso, inspecionavam, com o mesmo intuito, a parte distal do músculo constritor inferior da faringe. Com esta técnica, os autores foram capazes de identificar 36 (72\%) de 50 nervos pesuisados intra-operatoriamente. Utilizando apenas a laringoscopia direta e uma avaliaçäo fonoaudiológica no período pós-operatório, os autores notaram somente um caso de paralisia do MCT, num paciente submetido a uma tireoidectomia sub-total bilateral por bócio difuso tóxico. Houve uma hemorragia de dfícil controle na região do polo superior tireoideano, causada por um vaso que foi eletrocoagulado. O RELS, que foi em seguida visualizado, achava-se muito próximo a este vaso. 
Em 1990, FRIEDMAN \& PACELLA ${ }^{56}$ enfatizaram a necessidade de identificação do RELS antes de se efetuar qualquer ligadura na região do pedículo vascular superior da glândula tireóide. Esta identificação era feita sempre por intermédio de um neuro-estimulador, com uma intensidade de corrente da ordem de $1 / 2$ mili-Ampére. 


\section{CASUÍ́STICA E MÉTODOS}

\subsection{DISSECÇÕES ANATÔMICAS}

Antes de se iniciar o estudo clínico prospectivo, optou-se por uma fase preliminar de dissecções anatômicas, com o fito de proporcionar maior familiaridade com os aspectos morfológicos do RELS. Além disso, haveria a oportunidade de se anotarem as observações anatômicas e cotejá-las com as existentes na literatura.

Para estas dissecções, foram utilizados cadáveres não formolizados, de indivíduos adultos, de ambos os sexos, oriundos do Serviço de Verificação de Óbitos do Hospital das Clínicas da Faculdade de Medicina da Universidade de São Paulo.

O acesso cirúrgico ao compartimento central do pescoço foi obtido através da confecção de um grande retalho curvo cérvico-torácico, de concavidade cranial. Apesar de não mimetizar as condições cirúrgicas observadas no curso de uma tireoidectomia, esta técnica tinha a vantagem de situar toda e qualquer incisão externa em áreas não visíveis, com o corpo vestido. Este retalho foi elevado cranialmente num plano abaixo do músculo platisma, até se atingir o nível do osso hióide, oferecendo assim uma ampla exposição da área a ser analisada.

Procedeu-se, a seguir, à secção dos músculos esterno-hioídeo e esterno-tireoídeo, com a dissecção de ambos os lobos tireoideanos, cujas características foram cuidadosamente anotadas. Neste tempo, ambos os nervos recorrentes foram visualizados.

A região do triângulo esternohioídeo-laríngeo foi cautelosamente explorada, com especial atenção não apenas para a visualização do RELS como também para as suas relações anatômicas com o pedículo vascular superior tireoideano, com o músculo constritor inferior da faringe e com o MCT. Além disso, foram anotadas quaisquer anastomoses nervosas porventura existentes entre os nervos laríngeos superior e inferior. Finalmente, quando o RELS não foi passível de reconhecimento, 
foi largamente exposta toda a face lateral do pescoço, desde a base do crânio até a fossa supraclavicular, visando identificar um eventual trajeto aberrante do nervo.

Os dados obtidos foram anotados em esquema próprio e agrupados obedecendo a um critério anátomo-cirúrgico de risco potencial de lesão iatrogênica do RELS.

Quinze cadáveres, totalizando portanto trinta polos superiores tireoideanos, foram estudados. Os RELSs foram agrupados em três categorias (Fig. 3.1):

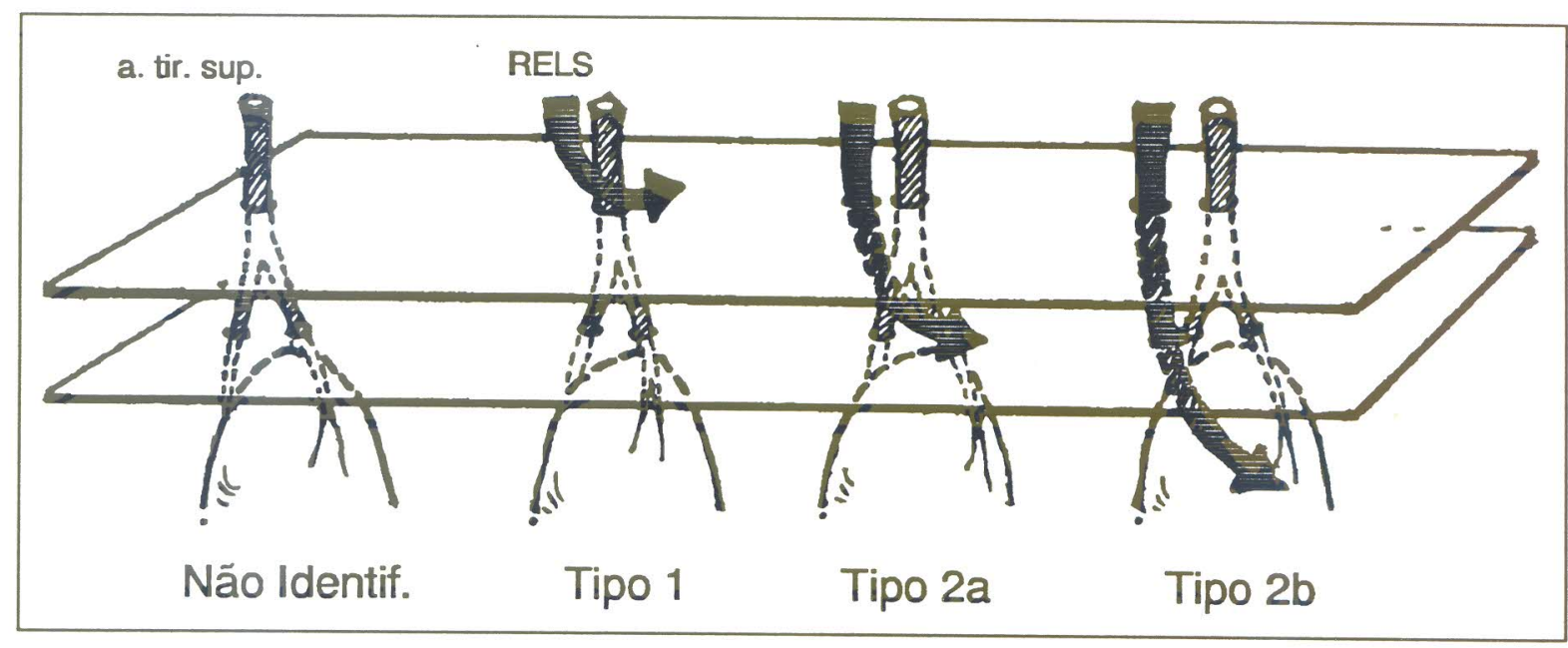

Figura 3.1

Classificação anátomo-cirúrgica dos RELS, em representação esquemática (v. texto).

A: nervo não identificado;

B: Tipo 1 nervo cruzando os vasos tireoideanos superiores 1 ou mais centímetros acima do plano horizontal que passava na borda superior do lobo tireoideano (exemplificado na Fig. $3.2)$;

C: Tipo 2: nervo cruzando os vasos tireoideanos superiores a menos de $1 \mathrm{~cm}$ acima ou então abaixo do plano supracitado:

Tipo 2a: nervo a menos de $1 \mathrm{~cm}$ acima do plano (demonstrado na Fig. 3.3);

Tipo 2b: nervo abaixo do plano (evidenciado na Fig. 3.4).

Os resultados obtidos se encontram resumidos na Tabela 3.1. É interessante notar que, dentre os 18 nervos do tipo 1, $5(28 \%)$ se achavam na intimidade das fibras do músculo constritor inferior da faringe. Outro aspecto que merece menção é que em apenas 7 (47\%) dos 15 cadáveres ambos os RELS eram do mesmo tipo.

Quanto ao nervo recorrente, ele apresentava bifurcações extra-laríngeas em $5(17 \%)$ ocasiōes e trifurcações em uma (3\%). Em apenas uma dissecção (3\%) foi constatada uma anastomose nervosa extra-laríngea entre o RELS e o nervo recorrente. 


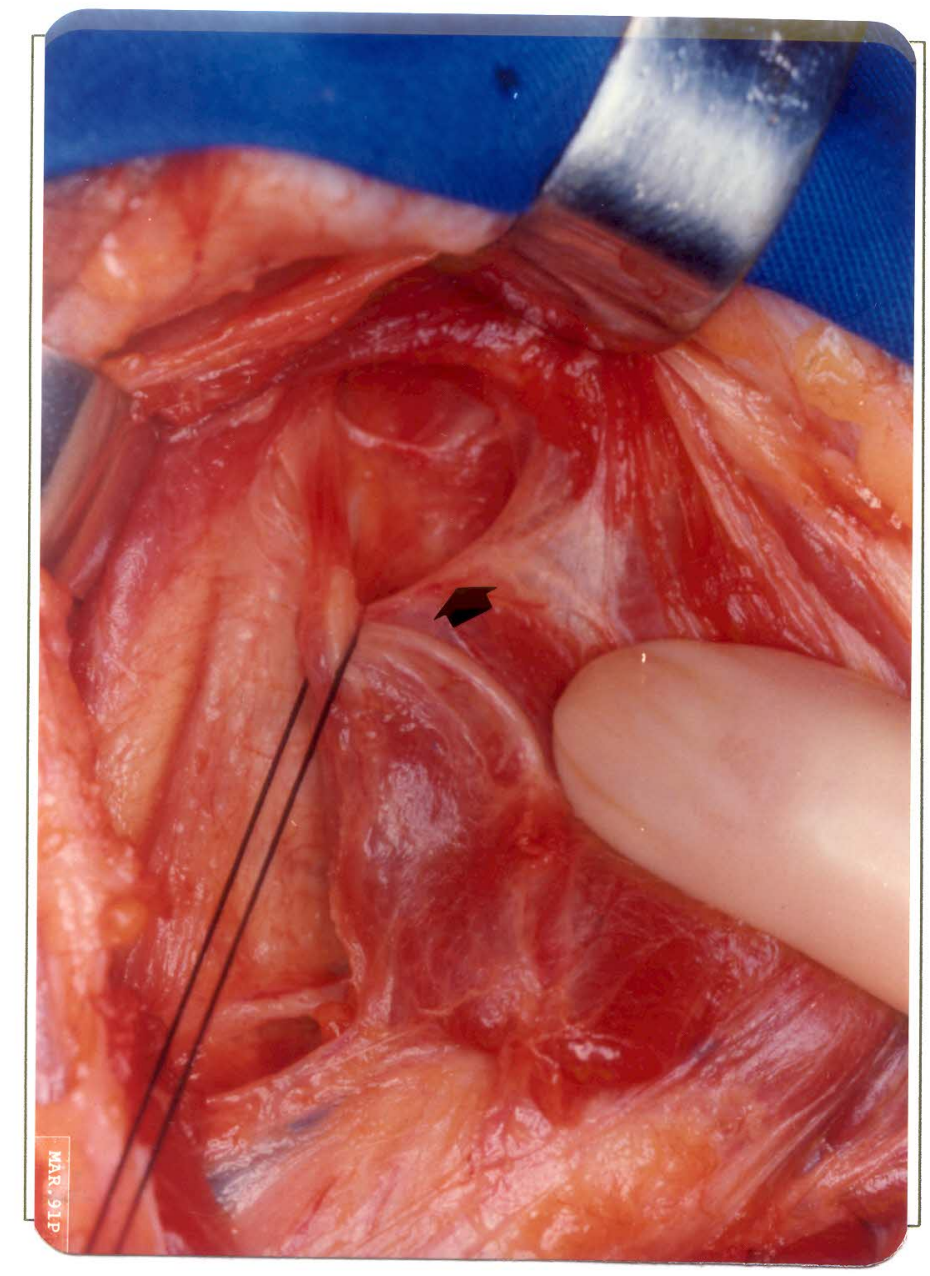

Figura 3.4

A seta evidencia um RELS do tipo $2 b$, cruzando o tronco da artéria tireoídea superior abaixo do polo superior tireoideano.

\subsection{ESTUDO CLÍNICO}

\subsubsection{AVALIAÇÃO PRÉ-OPERATÓRIA}

Foi preconizada a inclusão, neste estudo, de indivíduos com suspeita clínica de bócio uninodular simples atendidos no Ambulatório da DCCP-HC FMUSP.

Todos os doentes foram submetidos a uma completa anamnese e a um exame físico abrangente, com maior ênfase para o teritório cérvico-crânio-facial. A avaliação propedêutica foi completada, de forma rotineira, com os seguintes exames : hemograma completo, coagulograma, dosagens de uréia e creatinina, taxa de glicemia de jejum, dosagens de hormônios tireoideanos periféri$\cos$, mapeamento e captação de tireóide com I ${ }^{131}$, ultrassonografia cervical, radiografia simples de tórax em duas posições e eletrocardiograma. Nos doentes com idade superior a 50 anos ou portadores de cardiopatias foi efetuada uma avaliação cardiológica pré-operatória. Razões de ordem técnica (mudança nas instalações do Serviço de Punção-Biópsia por Agulha, cuja inatividade perdurou por 
vários meses) fizeram com que vários casos não pudessem ser avaliados com um estudo citológico pré-operatório. Foi parte integrante desta propedêutica pré-cirúrgica uma laringoscopia indireta, sendo a mobilidade normal das pregas vocais considerada condição necessária para o ingresso do caso no protocolo de estudo.

As indicações cirúrgicas, consoante as normas vigentes na DCCP-HC FMUSP e aceitas internacionalmente, foram: a) suspeita de malignidade; b) compressão de vias aéreas superiores; c) irresponsibilidade à terapêutica clínica; d)bócios mergulhantes; e) estética.

Uma vez consolidada a indicação cirúrgica e obtida a autorização do paciente, após uma clara exposição dos objetivos do estudo, teve início a avaliação específica da função vocal.

A avaliação fonoaudiológica começou sempre com uma entrevista dirigida e abrangente, visando detectar eventuais deficiências vocais, relacionadas ou não com a patologia tireoideana do indivíduo. Após esta anamnese direcionada, os pacientes foram submetidos a uma série de mensurações que tinham como objetivo delinear não só as características vocais de cada um, como também a sua capacidade respiratória. Alguns tempos, definidos abaixo, foram cronometrados:

a) tempo áfono (Taf) - após uma inspiração profunda, o doente era solicitado a fazer a expiração mais prolongada possível (medindo-se o tempo em segundos), sem emitir qualquer som;

b) tempo fônico de "a" (TFa) - idem, emitindo a vogal "a";

c) tempo fônico de "i" (TFi) - idem, emitindo a vogal "i";

d) tempo fônico de "s" (TFs) - idem, produzindo a consoante "s";

e) tempo fônico de "z" (TFz) - idem, produzindo a consoante " $z$ ";

f) coordenação pneumo-fono-articulatória - após uma inspiração profunda, o indivíduo era solicitado a contar, lenta e pausadamente, de " 1 " até o número que a sua resistência permitisse, sendo este o valor colocado nas tabelas de resultados.

Em seguida, a extensão vocal do paciente foi obtida, mediante a utilização de dois aparelhos, gentilmente cedidos pelo Prof. Dr. Paulo Augusto de Lima Pontes, Professor Titular da Disciplina de Otorrinolaringologia da Escola Paulista de Medicina, em sua clínica particular. Inicialmente, foram medidos no "Vocal-2 Visible Speech Training System" (Modern Electronics, Canada, 1981), os seguintes parâmetros:

a) freqüência fundamental - o indivíduo era solicitado a emitir a vogal " $i$ " (I), da forma que lhe fosse mais natural e confortável, a uma distância de 10 a $15 \mathrm{~cm}$ do microfone, aferindo-se a freqüência resultante em cps;

b) "i" grave (Ig)- idem, porém com a emissão do "i" mais grave possível;

c) "i” agudo (Ia)- idem, produzindo o "i" mais agudo possível;

d) extensão vocal (Iag) - considerou-se aqui a diferença entre o Ia e o Ig, ou seja, a amplitude da voz do indivíduo, indo do tom mais grave até o mais agudo que ele conseguisse produzir.

Este aparelho tinha a vantagem de contar com uma tela fluoroscópica (Fig. 3.5), na qual se podia visualizar gráficamente a emissão vocal. Entretanto, a sua sensibilidade era relativamente dificultada com a produção de freqüências vocais muito altas, devido ao seu alcance limitado. 
Por esta razão, as mensurações definitivas das freqüências supracitadas foram executadas no "Rhinolarynx Stroboscope type 4914" (Brüel \& Kjaer, Denmark, 1987), que possuía maior amplitude e sensibilidade de registros (faixa de 60 a $1500 \mathrm{cps}$ ). Aqui, o microfone era aplicado sobre a pele da região ântero-lateral do pescoço (Fig. 3.6).

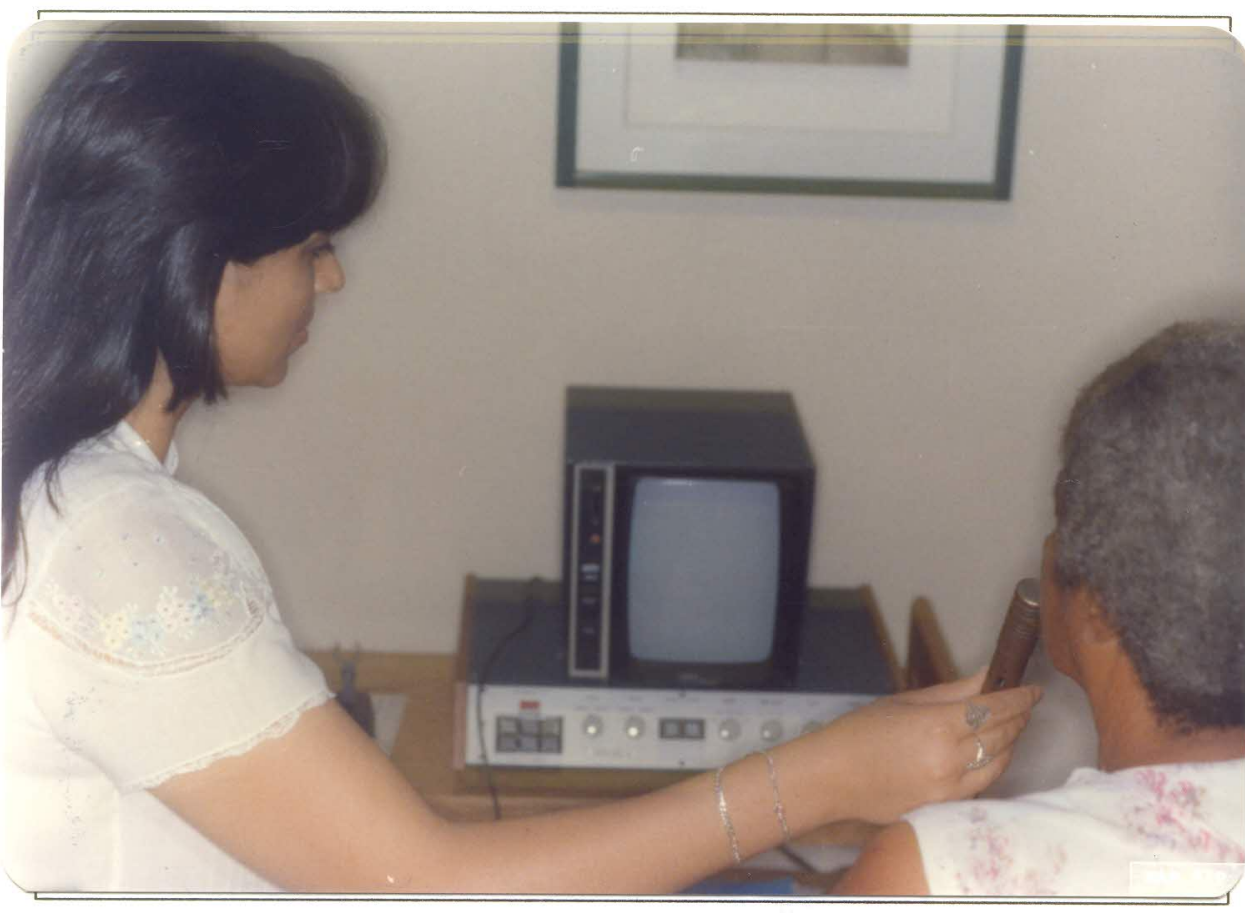

\section{Figura 3.5}

Avaliaçāo

fonoaudiológica

com o aparelho

"Vocal-2".

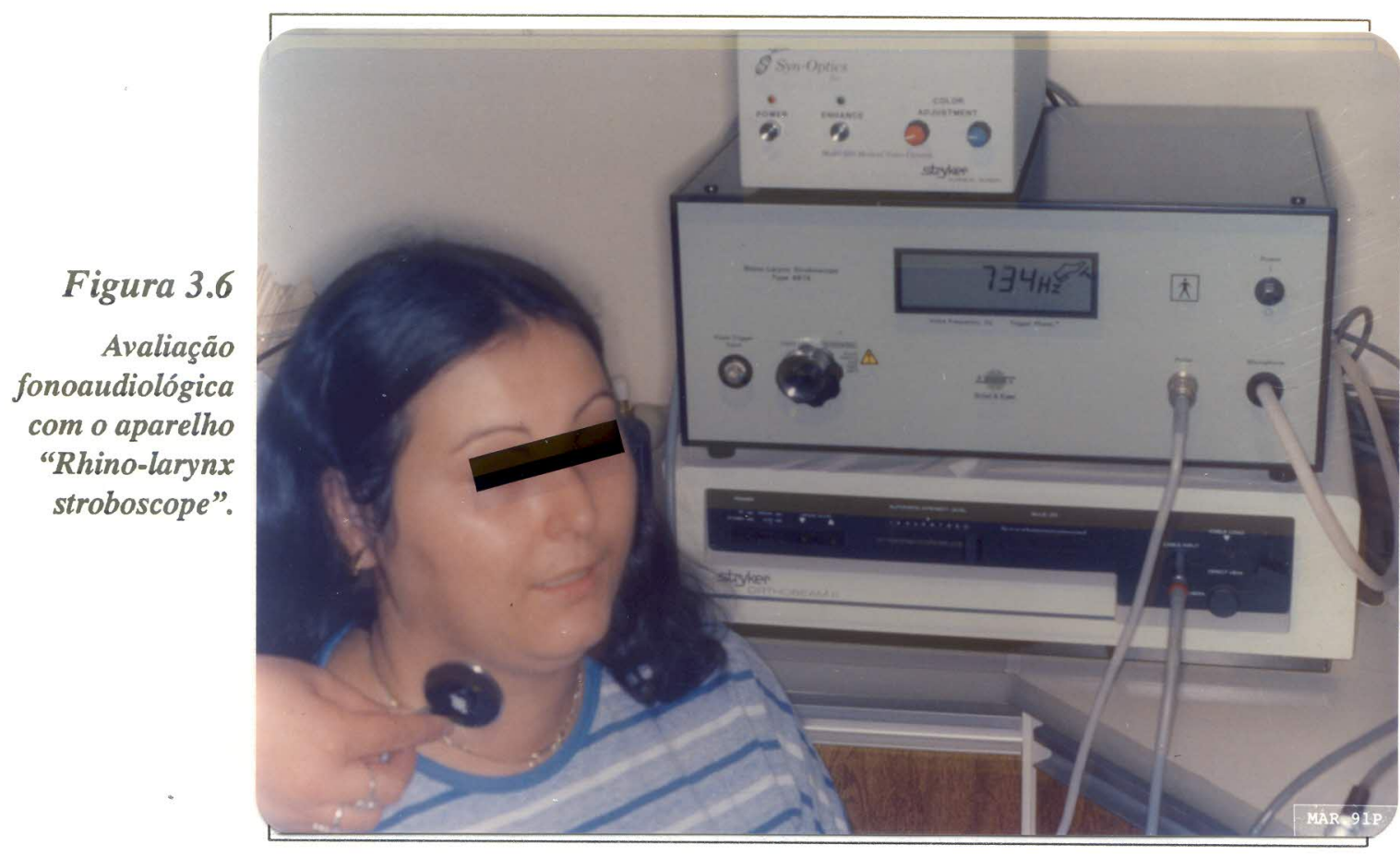




\subsubsection{GRUPOS CLÍNICOS}

Uma vez completada a fase de avaliação pré-operatória, os doentes foram internados na Enfermaria da DCCP-HC FMUSP e randomizados, através de sorteio, em três grupos, logo antes da cirurgia: 1,2 e 3.

Nos pacientes do Grupo 1, os polos superiores tireoideanos foram operados pelo Autor, procurando sempre identificar e preservar o RELS. No Grupo 2, os polos superiores tireoideanos foram dissecados por Médicos-Residentes de $2^{\circ}$ Ano, sem a preocupação de identificar o RELS. Já no Grupo 3, os polos superiores tireoideanos foram abordados cirurgicamente pelo Autor sem, contudo, qualquer tentativa de individualizar o RELS.

As características pré-operatórias dos 3 grupos foram comparadas, visando detectar eventuais distorções que, apesar da randomização efetuada, pudessem de alguma forma influir no estudo dos resultados. Foram analisados e cotejados: sexo, idade, diagnóstico e parâmetros da avaliação fonoaudiológica pré-operatória.

A distribuição dos casos quanto ao sexo foi semelhante nos três grupos (Tab. 3.2), não sendo a diferença significativa $(\mathrm{p}=0,6559)$. Considerando-se a totalidade dos pacientes, $67(88 \%)$ eram do sexo feminino e 9 (12\%) eram do sexo masculino, resultando numa proporção de 7,4:1.

Paralelamente, não foram observadas variações significativas quanto à idade $(p=0,7898)$ e cor $(p=0,7101)$, conforme mostram as Tabelas 3.3 e 3.4. Na totalidade dos casos do estudo, a idade média foi 37 anos, variando de 14 a 62 anos. A proporção global de pacientes de cor branca em relação aos não-brancos foi de 3,5:1.

\section{TABELA 3.2 \\ DISTRIBUIÇÃO POR SEXO}

\begin{tabular}{ccc}
\hline & Sexo Masc. & Sexo Fem. \\
\hline Grupo 1 & $2(7,7 \%)$ & $24(92,3 \%)$ \\
Grupo 2 & $4(16,0 \%)$ & $21(84,0 \%)$ \\
Grupo 3 & $3(12,0 \%)$ & $22(88,2 \%)$ \\
\cline { 2 - 3 } Total & $9(11,8 \%)$ & $67(88,2 \%)$ \\
\hline & & $\mathrm{p}=0,6559$
\end{tabular}

\section{TABELA 3.3 \\ IDADE MÉDIA}

\begin{tabular}{cc}
\hline Grupo & Idade (anos) \\
\hline 1 & 37 \\
2 & 39 \\
3 & 37 \\
\hline & $\mathrm{p}=0,7898$
\end{tabular}




\section{TABELA 3.4 \\ DISTRIBUIÇÃO POR COR}

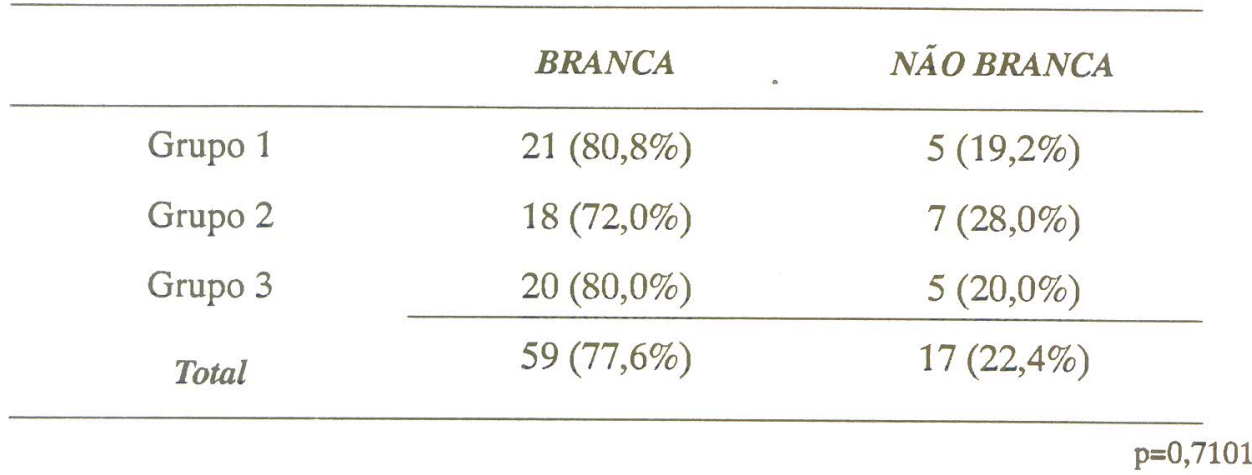

\subsubsection{TÉCNICA CIRÚRGICA}

Após a indução anestésica e intubação orotraqueal com sonda aramada, a antissepsia da pele foi feita com preparado não-iodado, seguindo-se a colocação de campos estéreis.

Nos indivíduos do grupo 1, a incisão, sempre transversa, ligeiramente arqueada e, se possível, numa prega cutânea natural, incluiu pele, tecido celular subcutâneo e músculo platisma, fazendo-se a hemostasia com bisturi elétrico (Fig. 3.7). O subsequente descolamento dos retalhos cranial (até se identificar a cartilagem tireóide) e caudal (até atingir a fúrcula esternal) foi executado num plano abaixo do músculo platisma (Fig. 3.8). Após a abertura da linha média, abordou-se a loja tireoideana, com exploração e análise global da glândula (Fig. 3.9). Foi feita a secção dos músculos esterno-hioídeo e esterno-tireoídeo entre duas pinças hemostáticas retas, de maneira a proporcionar o seu afastamento e melhor visualizaçào do polo superior tireoideano correspondente ao lado afetado (Fig. 3.10). Neste tempo, se a veia tireoideana média fosse visualizada, na face média do lobo tireoideano, era ligada e seccionada, a fim de proporcionar maior segurança na tração caudal e medial do lobo. Procurou-se expor sempre o MCT, dissecando e afastando anteriormente, se necessário, o lobo piramidal. Antes de se efetuar qualquer ligadura dos ramos arteriais e venosos tireoideanos superiores, teve início uma pesquisa cuidadosa e sistemática do RELS na região do triângulo esternotireoídeo-laríngeo. Neste grupo, este tempo operatório foi sempre executado pelo autor, com o auxílio de uma lupa binocular "Keeler" grande angular de 2,5 aumentos (Keeler Panoramic Loupes, Berkshire, England). Qualquer estrutura anatômica que se assemelhasse ao nervo em questão era estimulada com um neuro-estimulador "Vari-Stim" (Concept, Inc., Clearwater, USA) (Fig. 3.11), numa intensidade de corrente oscilando entre 0,5 e 2,0 miliAmpéres, observando-se, caso a identificação fosse positiva, uma evidente contração do MCT ipsilateral no próprio campo operatório (Fig 3.12). Após a comprovação da posição do RELS, que foi anotada em cada caso, os ramos vasculares foram individualmente seccionados e duplamente ligados com fio inabsorvível 4-0, mantendo-se sempre o nervo sob visão direta (Fig. 3.13). Na eventualidade de não ser factivel a identificação do RELS, qualquer estrutura próxima ao polo superior tiroideano, incluindo os próprios ramos vasculares, foi eletricamente estimulada, antes da sua secção e ligadura. Neste tempo operatório, foi identificada e preservada a glândula paratireóide superior. O tempo adicional gasto para a dissecção e identificação do nervo foi anotado, em minutos. 


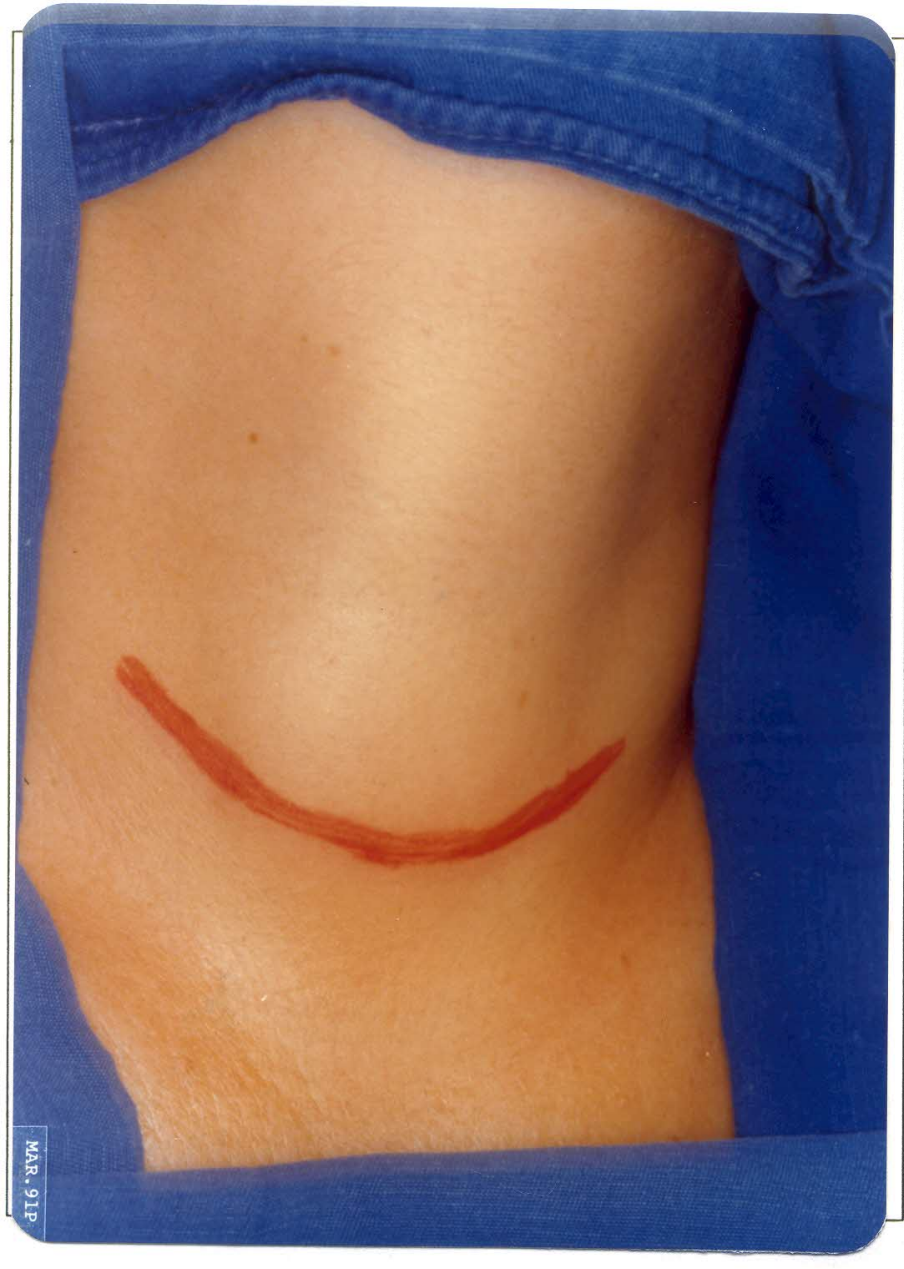

Figura 3.7 -

Incisão cutânea.

Figura 3.8 -

Dissecção dos retalhos cranial e caudal.

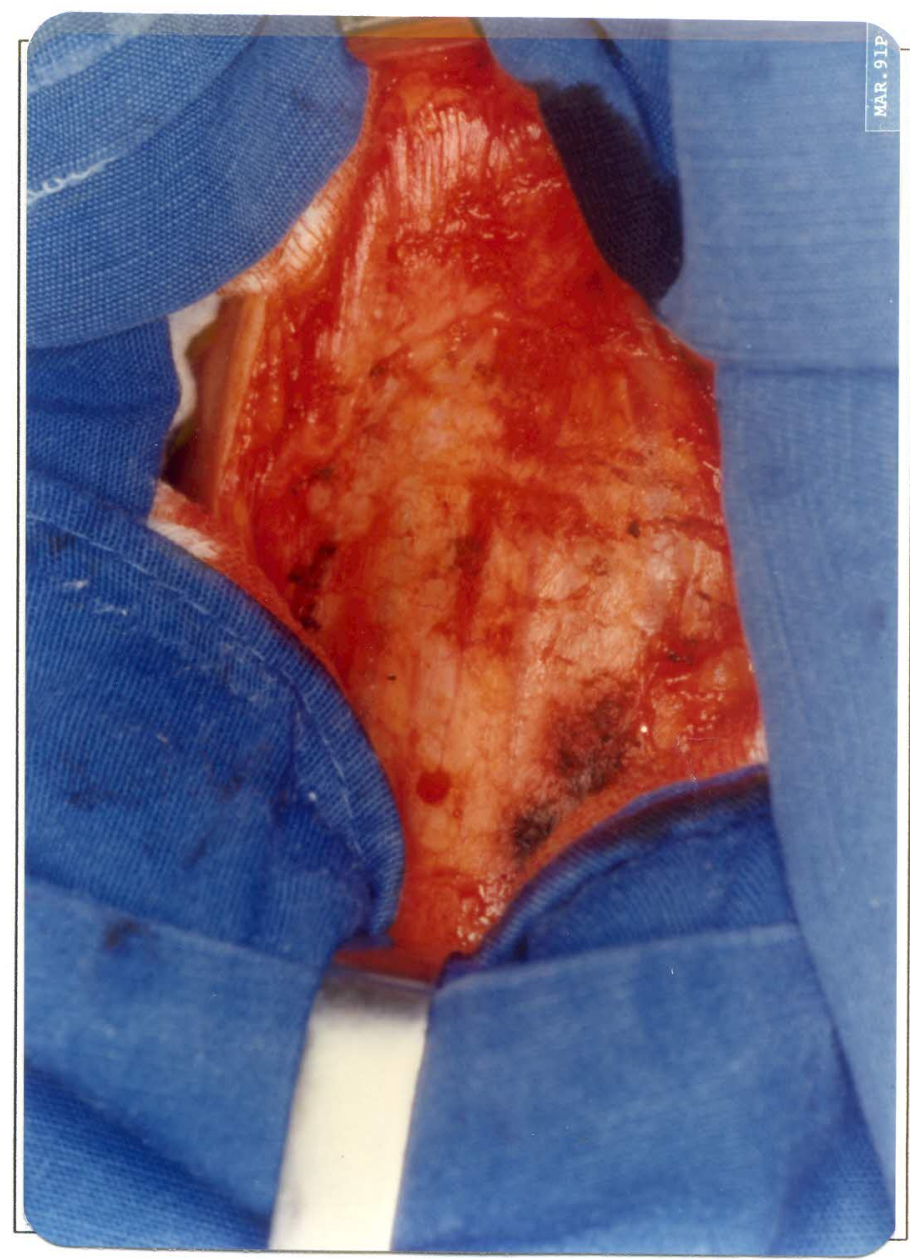




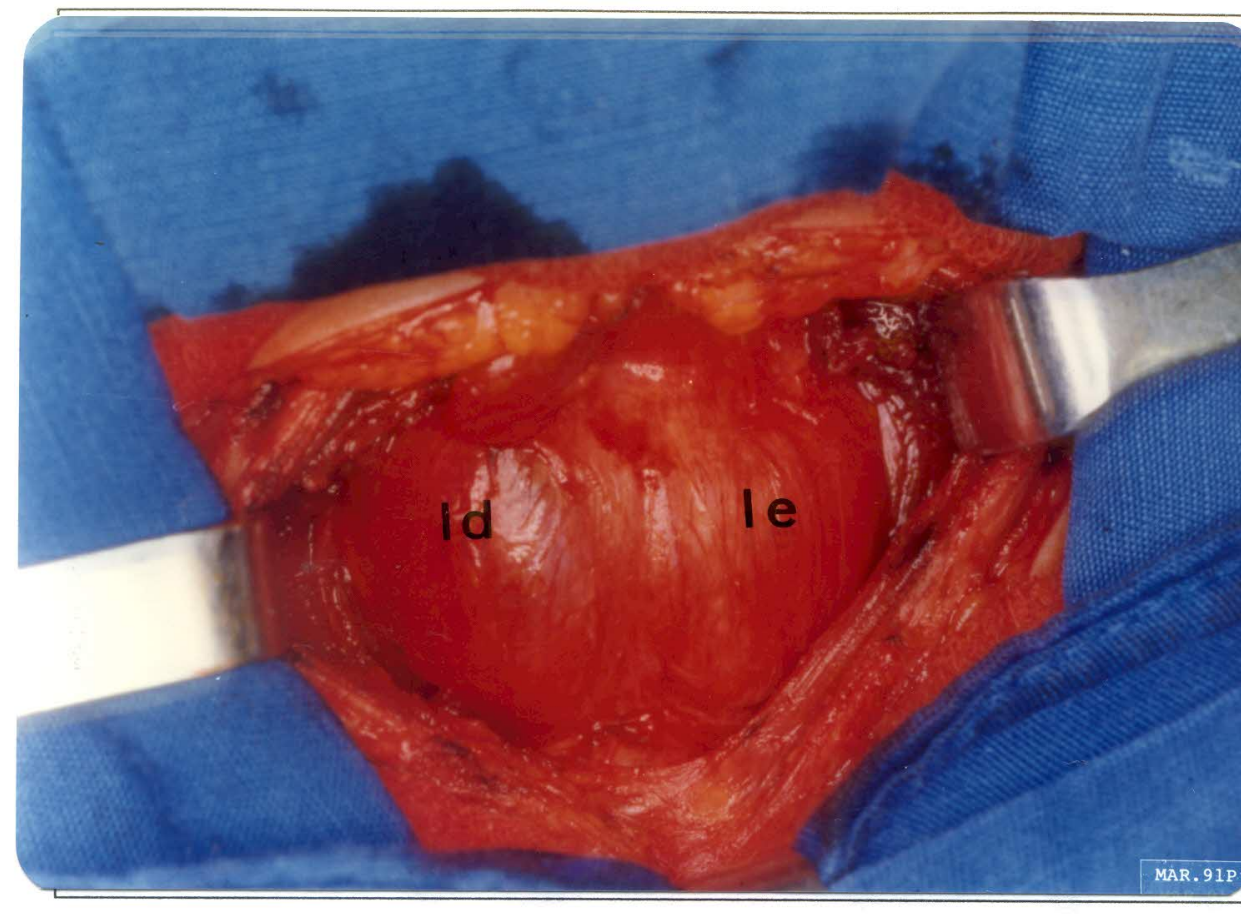

Figura 3.9 -

Exposição da loja tireoideana;

ld: lobo direito;

le: lobo esquerdo.

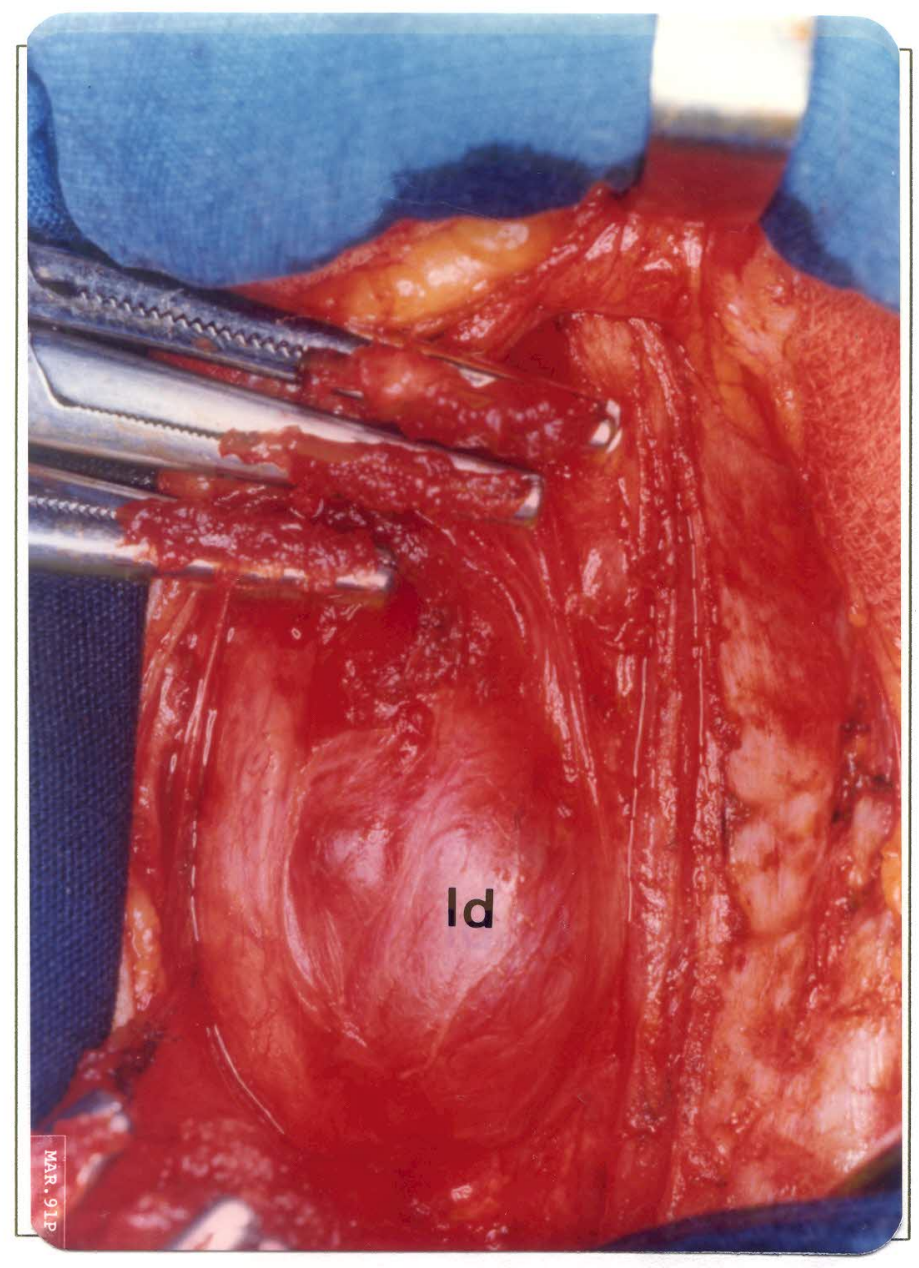

Figura 3.10 -

Secção dos músculos pré-tireoideanos; ld: lobo direito. 
Figura 3.11 -

Neuroestimulador

"Vari-Stim III"
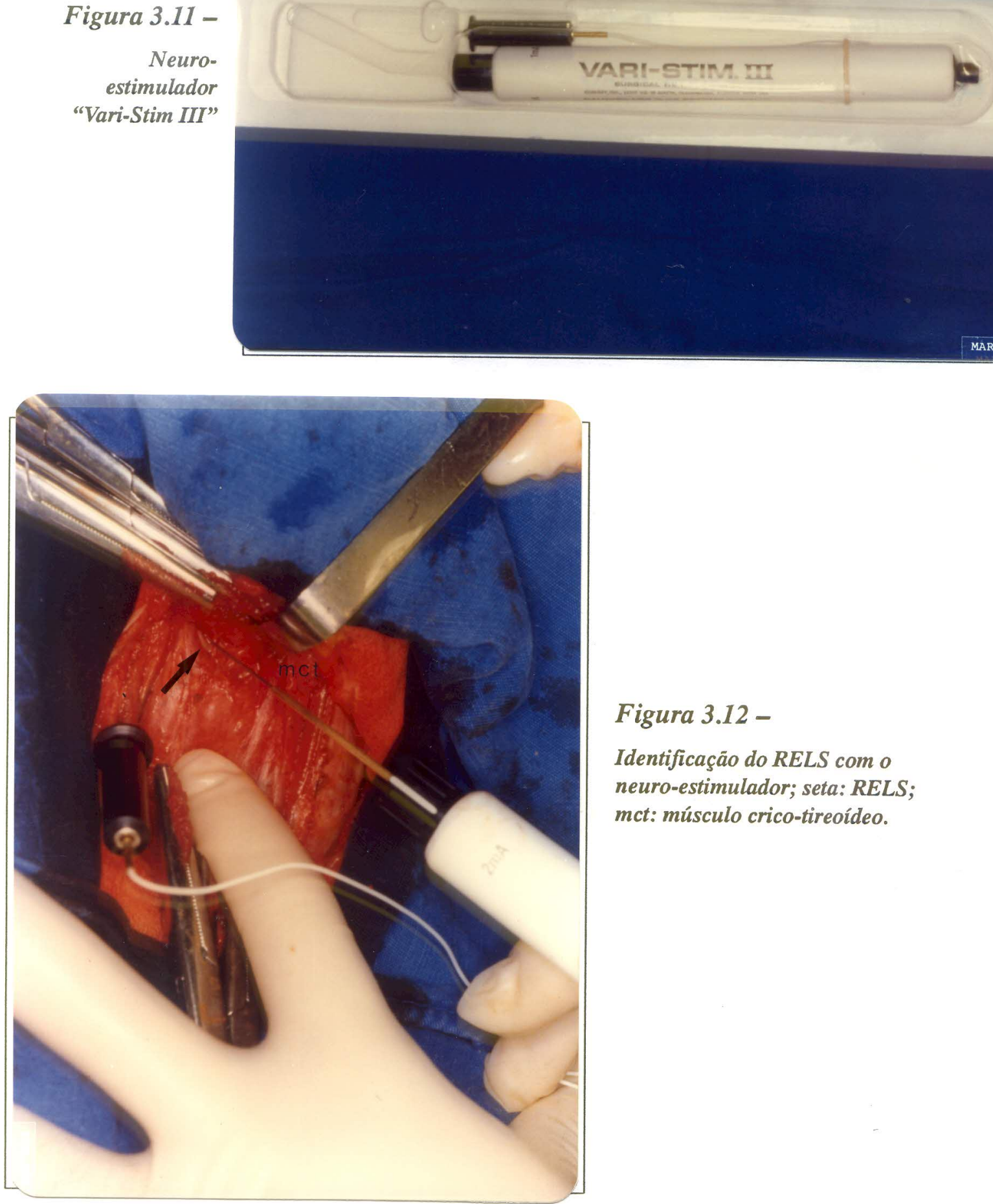

Figura 3.12 -

Identificaçäo do RELS com o

neuro-estimulador; seta: RELS;

mct: músculo crico-tireoideo. 


\section{Figura 3.13 -}

Dissecção do polo superior direito; seta: RELS; ps: gl.paratireóide superior direita; ld: lobo direito.

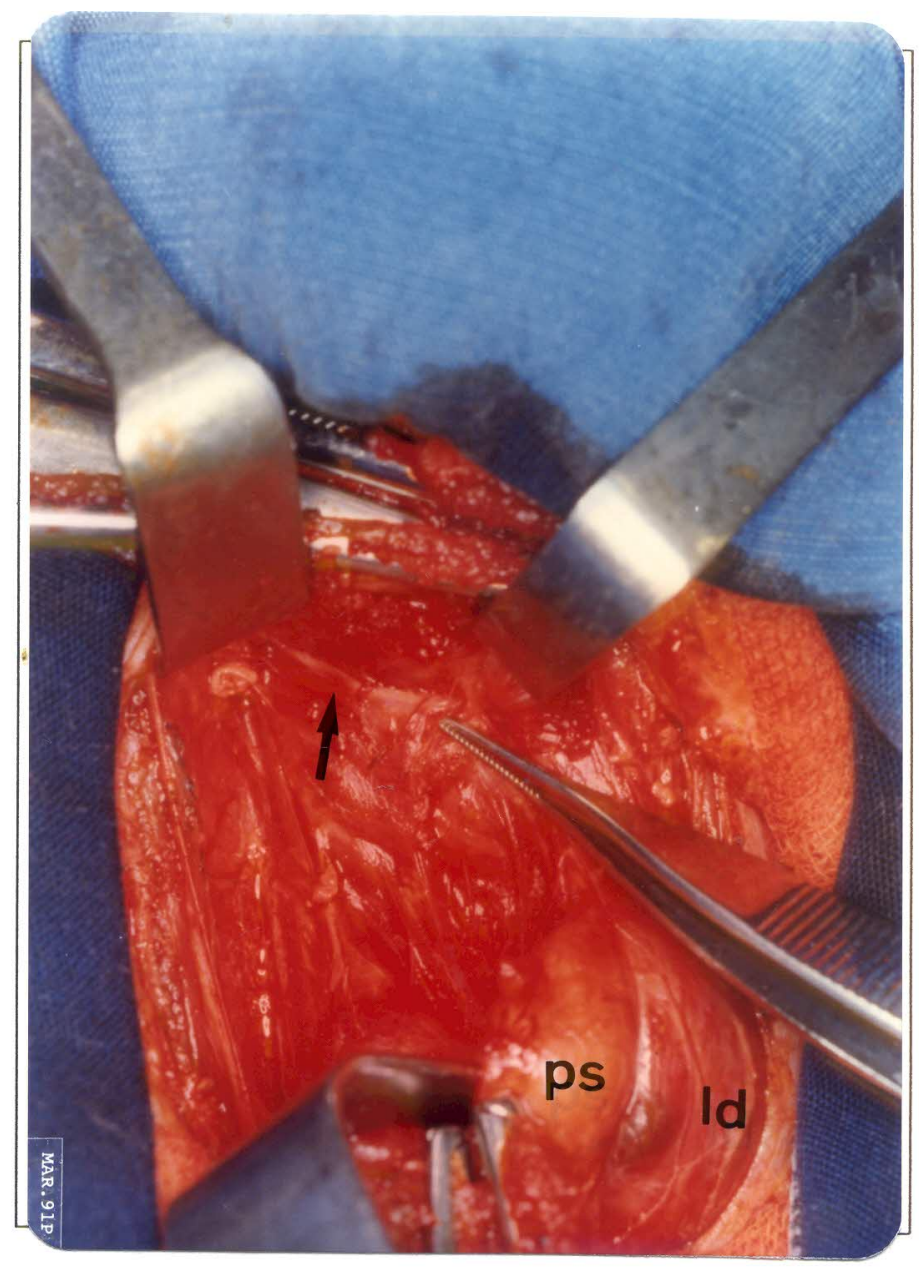

No Grupo 2, a incisão utilizada foi a mesma, incluindo, no entanto, apenas a pele e o tecido celular subcutâneo. O descolamento dos retalhos cranial e caudal foi realizado num plano acima do músculo platisma. Após a abertura da linha média e exploração da loja tireoídea, teve início a liberação do polo superior, sem a secção dos musculos pré-tireoideanos, obedecendo às normas técnicas utilizadas na DCCP-HC FMUSP. Os ramos vasculares tireoideanos superiores foram identificados, seccionados e ligados duplamente com fio inabsorvível 4-0, o mais rente possível ao polo superior da glândula, evitando-se ligaduras altas ou que englobassem uma grande massa de tecido. Não foi feita aqui qualquer tentativa para a identificação do RELS. Neste Grupo, este tempo operatório foi realizado por um Médico-Residente de 20. Ano de Cirurgia Geral, estagiando pelo período de um mes na DCCP-HC FMUSP.

Já no Grupo 3, os passos operatórios obedeceram exatamente à mesma sequência do grupo anterior, com a diferença que a abordagem cirúrgica do pedículo tireoideano superior foi executada sempre pelo Autor, auxiliado pelo mesmo instrumento óptico já descrito.

Os tempos subsequentes da lobectomia obedeceram, nos três grupos, à técnica empregada habitualmente na DCCP-HC FMUSP e foram feitos, nos três grupos, sempre por um MédicoResidente de 20. Ano. Após a secção da veia tireoídea média (caso ela ainda não tivesse sido abordada), afastou-se medialmente o lobo tireoideano, com o intuito de expor a sua face lateral. Identificou-se o tronco da artéria tireoídea inferior, que foi reparado, seguindo-se a individualização do 
nervo recorrente e da glândula paratireóide inferior, que foram todos preservados (Fig.3.14). Ligou-se o pedículo venoso inferior da glândula tireóide, continuando a dissecção do lobo tireoideano e efetuando a ligadura individualizada dos ramos da artéria tireoídea inferior rente à glândula, mantendose sempre as glândulas paratireóides e o nervo recorrente sob visão direta. Completada a lobectomia, sempre acompanhada de istmectomia e incluindo também a retirada do lobo piramidal, se presente, a peça foi enviada para exame anátomo-patológico de congelação, anotando-se peso e dimensões. Em doentes portadores de bócios multinodulares, constatados apenas no intra-operatório, o tratamento dos nódulos porventura existentes no outro lobo foi feito de acordo com cada situação, variando de simples nodulectomias até lobectomias subtotais. Evidentemente, se foi necessária a abordagem do polo superior contralateral, ela foi executada mantendo-se a metodização usada no outro lobo. Se o resultado foi benigno, o ato operatório foi dado por encerrado, tomando-se o cuidado de, durante a síntese dos planos cirúrgicos, não se olvidar, nos casos do Grupo 1, a sutura dos músculos esternohioídeo e esterno-tireoídeo previamente seccionados com pontos separados de fio absorvível 3-0 (Fig. 3.15). Se o resultado foi maligno, completou-se a tireoidectomia total através da lobectomia contralateral utilizando exatamente a mesma sequência cirúrgica empregada no primeiro lobo, com o

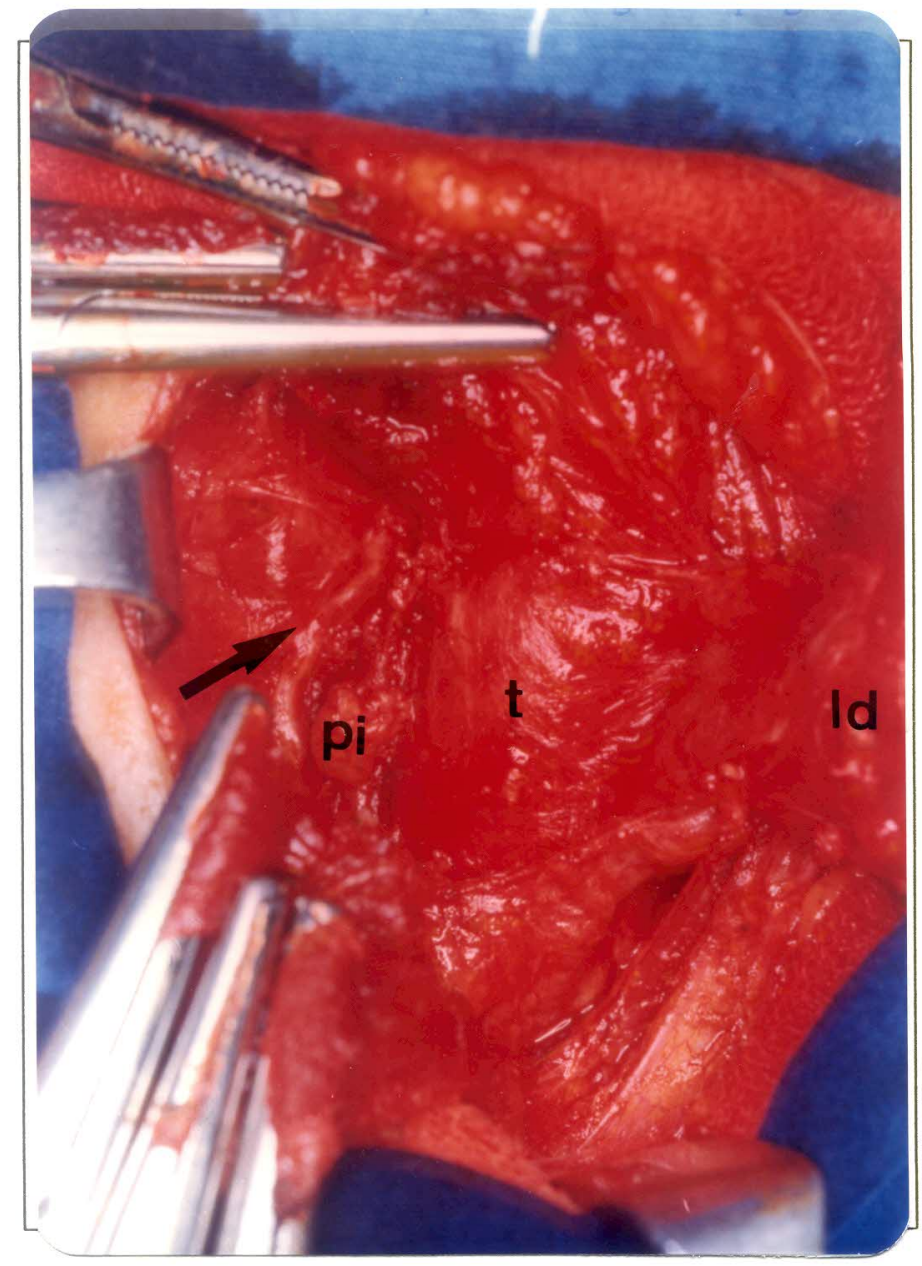

Figura 3.14 - Completada a dissecção do lobo direito; seta: nervo recorrente; $t$ : traquéia; pi: gl. paratireóide inferiordireita; ld: lobo direito. 


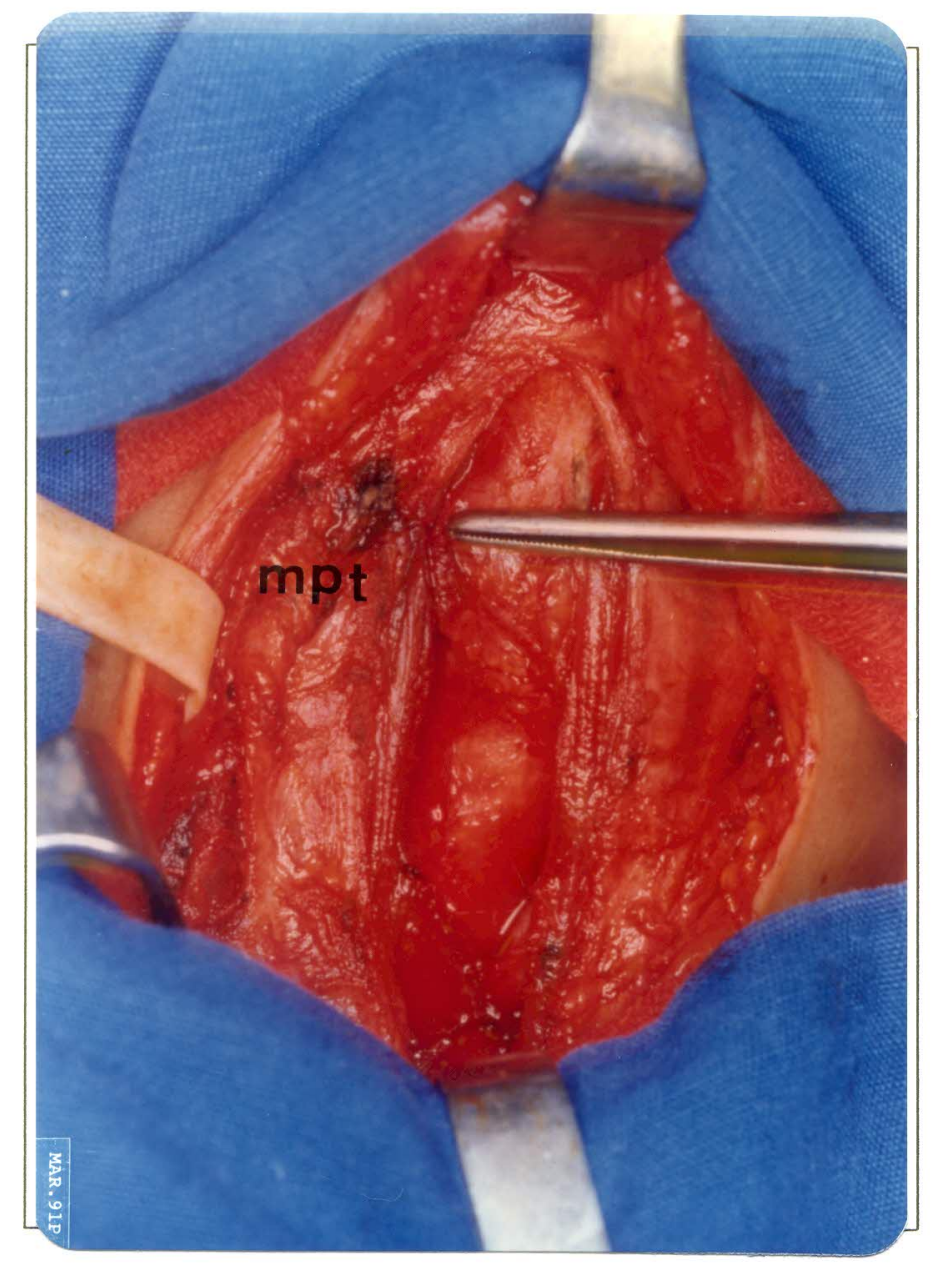

\section{Figura 3.15 -}

Síntese dos músculos pré-tireoideanos, com a pinça apontando para a linha de sutura; mpt: músculos pré-tireoideanos.

intuito de se preservar a homogeneidade da casuística. Em caso de dúvida na biópsia de congelação, a cirurgia era encerrada e aguardava-se o laudo definitivo, que veio depois de 2 a 10 dias. Confirmando-se o diagnóstico de tumor maligno, o doente foi reoperado, mantendo-se a técnica empregada na cirurgia anterior.

O tempo decorrido entre o início e o término da anestesia foi anotado, considerandose, nas reoperações, tempos diferentes para cada ato operatório.

Apesar da randomização, houve um número maior de tireoidectomias totais nos Grupos 2 ( 6 casos) e 3 ( 5 casos) em relação ao Grupo 1 ( 2 casos). Similarmente, observaram-se mais reoperações nos grupos 2 ( 5 doentes) e 3 ( 4 doentes) do que no Grupo 1, no qual nenhum caso foi reoperado. Estas discrepâncias, porém, não foram significativas, à análise estatística $(p=0,4125)$. Um dado surpreendente foi que, dentre as 13 tireoidectomias totais, todas para tumores malignos, apenas 4 foram executadas num mesmo ato operatório, ao passo que em 9 casos houve necessidade de uma reoperação para se totalizar a tireoidectomia. Por outro lado, os números de RELSs colocados sob risco pela abordagem cirúrgica do polo superior tireoideano correspondente foram 28,31 e 31 , respectivamente nos Grupos 1, 2 e 3. Estes números não diferiram significativamente $(p=0,6245)$.

O tempo médio de duração dos atos operatórios foi cotejado entre os três grupos (Tab. $3.5)$, não revelando diferença significativa $(\mathrm{p}=0,3639)$. Para a totalidade dos casos, o tempo operatório variou de 150 a 300 minutos, com uma média de 199 minutos. 
No tocante às características das peças operatórias, as suas dimensões médias, comparadas entre os três grupos, podem ser aquilatadas na Tab. 3.6, não exibindo variações de importância ( $p=0,0744, p=0,1262$ e $p=0,1707$, respectivamente para as três mensurações). As dimensões médias dos lobos tireoideanos ressecados foram: $55 \mathrm{mmX} 38 \mathrm{mmX} 25 \mathrm{~mm}$. Já os lobos retirados para a totalização das tireoidectomias apresentaram as seguintes dimensões médias: $34 \mathrm{mmX} 26 \mathrm{mmX14mm}$. No que tange ao peso (Tab. 3.7), também não se evidenciaram discrepâncias significativas ( $p=0,4413)$ entre os três grupos. No total, este peso oscilou entre 10 e 230 gramas, com uma média de 31 gramas. Nos produtos das totalizações das tireoidectomias, este peso sitou-se entre 10 e 90 gramas, com uma média de 13 gramas.

\section{TABELA 3.5 \\ TEMPO DE DURAÇÃO DAS CIRURGLAS}

\begin{tabular}{|c|c|}
\hline Grupo & Duração (min) \\
\hline 1 & 207 \\
\hline 2 & 197 \\
\hline 3 & 193 \\
\hline
\end{tabular}

TABELA 3.6

DIMENSÖES DOS LOBOS

\begin{tabular}{lcccc} 
& $\begin{array}{c}\text { Grupo } \\
\mathbf{1}\end{array}$ & $\begin{array}{c}\text { Grupo } \\
\mathbf{2}\end{array}$ & $\begin{array}{c}\text { Grupo } \\
\mathbf{3}\end{array}$ & $\boldsymbol{p}$ \\
\hline Dim. 1(mm) & 54 & 59 & 49 & 0,0744 \\
Dim. 2(mm) & 34 & 40 & 41 & 0,1262 \\
Dim. 3(mm) & 22 & 27 & 24 & 0,1707 \\
\hline
\end{tabular}

TABELA 3.7

PESO DOS LOBOS

\begin{tabular}{cc}
\hline Grupo & Peso $(g)$ \\
\hline 1 & 26 \\
2 & 31 \\
3 & 36 \\
\hline & $\mathrm{p}=0,4413$
\end{tabular}


A distribuição dos diferentes diagnósticos histológicos pode ser analisada na Tabela 3.8. Embora o montante de tumores malignos tenha sido maior nos Grupos 2 e 3, esta diferença não foi estatisticamente significativa $(p=0,2711)$.

\section{TABELA 3.8 \\ DISTRIBUIÇÃO POR DIAGNÓSTICO HISTOLÓGICO}

\begin{tabular}{cccc}
\hline Diag. Histológico & Grupo 1 & Grupo 2 & Grupo 3 \\
\hline Bócio Adenomatoso & 23 & 16 & 15 \\
Adenoma Folicular & - & 2 & 3 \\
Adenoma Hurthle & 1 & - & - \\
Cisto Hemorrágico & - & 1 & 1 \\
Tireoidite & - & - & 1 \\
Hashimoto & & & \\
Ca Papilífero & 2 & 2 & 2 \\
Ca Folicular & - & 3 & 3 \\
Ca Hurthle & - & 1 & - \\
\cline { 2 - 4 } & 26 & 25 & 25 \\
\hline
\end{tabular}

No Grupo 1, 28 RELS foram pesquisados. Adotando-se a mesma classificação anteriormente descrita, não foram identificados os nervos em $2(7 \%)$ casos, constatando-se uma incidência do Tipo 1 em 19 (68\%), do Tipo 2a em 3 (11\%) e do Tipo 2b (Fig. 3.16) em 4 (14\%). Estes resultados podem ser comparados com aqueles obtidos nas dissecções anatômicas efetuadas na primeira parte deste estudo, como se observa na Figura 3.17. O tempo gasto para uma identificação positiva do nervo variou de 1 a 50 minutos, com uma média em torno de 13 minutos. Nas duas situaçōes em que o RELS não foi visualizado, o tempo empregado na sua procura foi de 50 e 28 minutos, respectivamente.

Quanto à morbidade, levando-se em conta o total de pacientes operados (87), ocorreram: um caso $(1,1 \%)$ de paralisia temporária e um caso $(1,1 \%)$ de paralisia definitiva de prega vocal, ambos excluídos da análise final. Além destes, um paciente $(1,1 \%)$ exibiu um hipoparatireoidismo transitório, que demandou uma reposição de cálcio por via oral durante um período de 4 meses após a cirurgia. Não houve hematomas ou infecções da ferida operatória. Não houve mortalidade nesta casuística. 


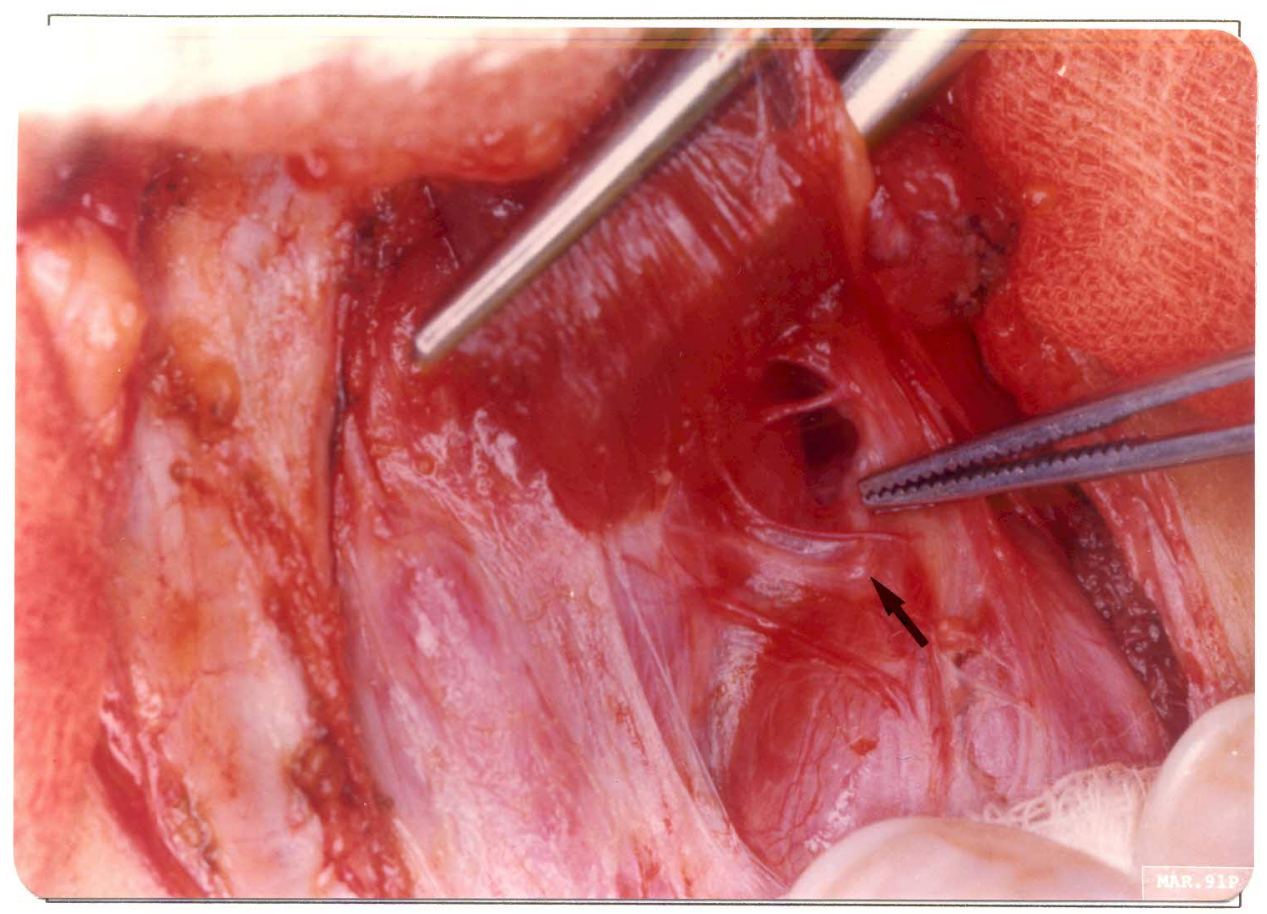

Figura 3.16 - A seta aponta para RELS tipo $2 b$ (caso clínico).

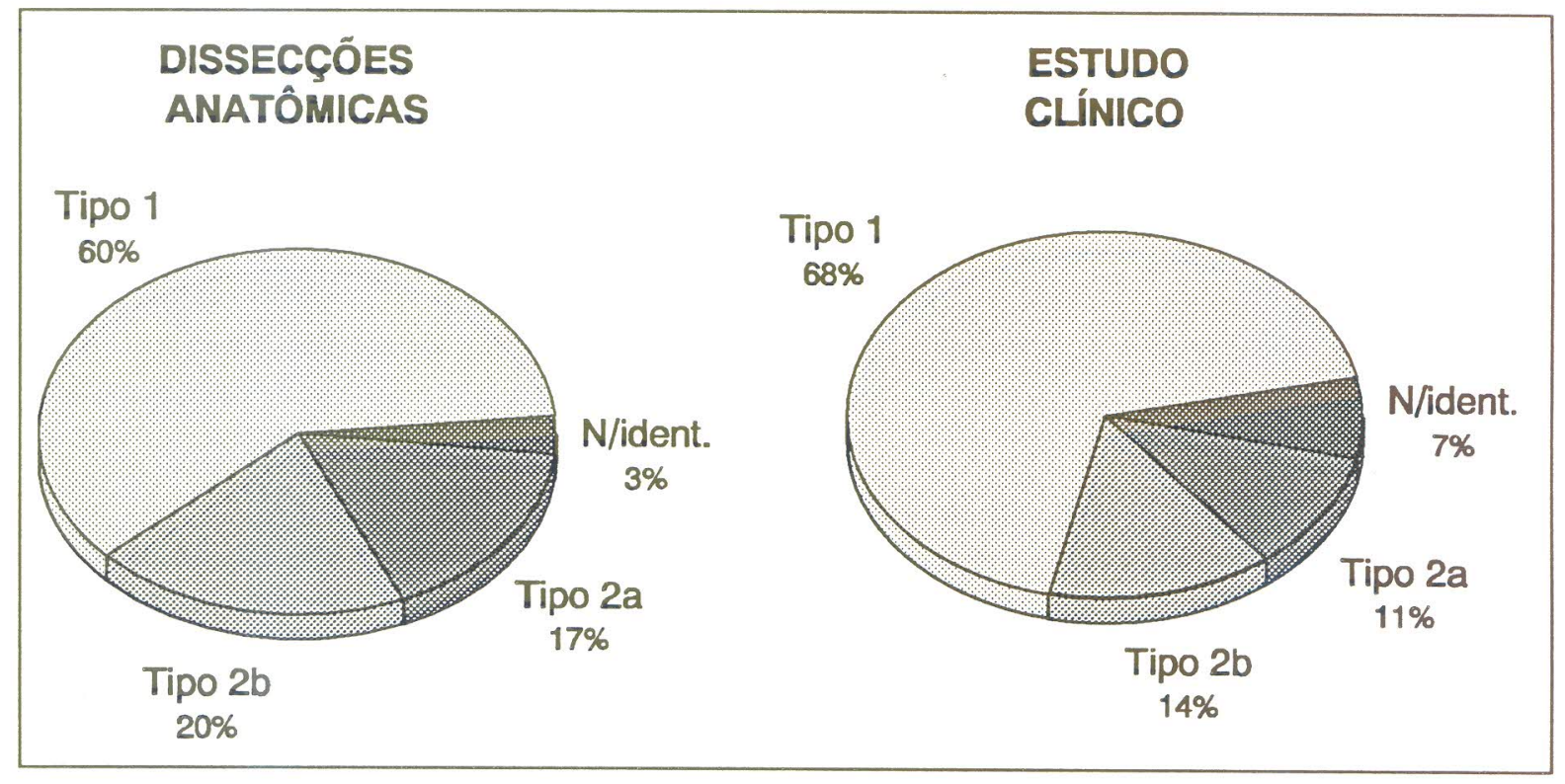

Figura 3.17 - Tipos de RELS 


\subsubsection{AVALIAÇÃO PÓS-OPERATÓRIA PRECOCE}

Os pacientes foram submetidos a uma laringoscopia indireta no primeiro dia após a operação, recebendo alta hospitalar habitualmente entre o 1o. e 3o. dias do período pós-operatório.

Geralmente entre 4 e 10 dias após a cirurgia, os pacientes sofreram uma nova avaliação fonaudiológica completa, comparando-se os resultados com aqueles obtidos antes da tireoidectomia.

Aproximadamente 30 dias depois da operação, foi efetuado um estudo eletromiográfico do MCT, no Departamento de Anatomia do Instituto de Ciências Biomédicas da Universidade de São Paulo, pelo Prof. Dr. José Furlani, Professor Titular do Departamento. O aparelho utilizado foi um eletromiógrafo TECA modelo TE 2-7, de 4 canais, doado ao Departamento de Anatomia pela Fundação de Amparo à Pesquisa do Estado de São Paulo (FAPESP), conforme o processo médico 73/178. Após uma antissepsia da pele com substância não iodada, introduziu-se um eletrodo de agulha coaxial bipolar (previamente esterilizado em óxido de etileno) na linha média, na altura da borda superior da cartilagem cricóide, direcionando-o oblíqua e lateralmente rumo ao MCT direito (Fig. 3.18). O eletrodo foi conectado ao aparelho, obtendo-se o registro eletromiográfico do músculo em repouso. Solicitou-se, então, ao indivíduo que emitisse a vogal "i" mais aguda que fosse capaz. No caso de integridade funcional do complexo RELS-MCT, constatou-se um aumento substancial da atividade elétrica do MCT à produção de sons agudos (Fig. 3.19), observando-se um silêncio elétrico quando a sua inervação estivesse comprometida (Fig. 3.20). Completada a avaliação do MCT direito, a agulha foi retrocedida, sem contudo retirá-la da pele, e, aproveitando o mesmo orifício da punção, abordou-se o músculo contralateral, repetindo a sequência do exame. Os parâmetros do eletromiógrafo foram: velocidade de varredura: 300 milissegundos/divisão; amplitude: entre 200 e 500 microVolts/divisão. Os resultados foram gravados em papel foto-sensível "Kodak-Linagraph Direct Print", tipo 1895, Standard.

Não houve, no registro da atividade eletromiográfica dos MCTs, uma preocupação maior com aspectos quantitativos desta atividade, mas sim com a comprovação qualitativa da sua presença. Isto se deveu à observação, durante a feitura de alguns exames, que o deslocamento do eletrodo de apenas alguns milímetros, na intimidade do $\mathrm{MCT}$, era responsável por profundas alterações no traçado eletromiográfico (Fig. 3.21). Entretanto, o insofismável valor do método, principalmente no tocante à comprovação da paralisia total do RELS e à identificação do lado lesado, em tireoidectomias bilaterais, fez com que a eletromiografia fosse considerada, neste estudo, como o exame comprobatório da lesão completa do RELS.

Os resultados obtidos à eletromiografia precoce também foram analisados de outra maneira. Já que este exame permitia a comprovação indiscutível do lado em que a lesão do RELS havia ocorrido, optou-se por comparar os nervos submetidos ao risco de lesão operatória pela dissecção do polo superior correspondente nos diferentes grupos com os nervos que não sofreram este risco, ou seja, aqueles correspondentes aos polos superiores não dissecados. Como os MCTs por eles inervados também foram avaliados pela eletromiografia e se mostraram invariavelmente normais, criou-se aqui a possibilidade de um novo contingente de controle, que oferecia a vantagem de uma análise estatística mais fidedigna, pelo seu número mais elevado. Destarte, um novo grupo, denominado 4 , composto pelo conjunto de todos os polos superiores não dissecados nos três grupos, foi constituído. Os dados obtidos nos outros três grupos foram com ele comparados. 


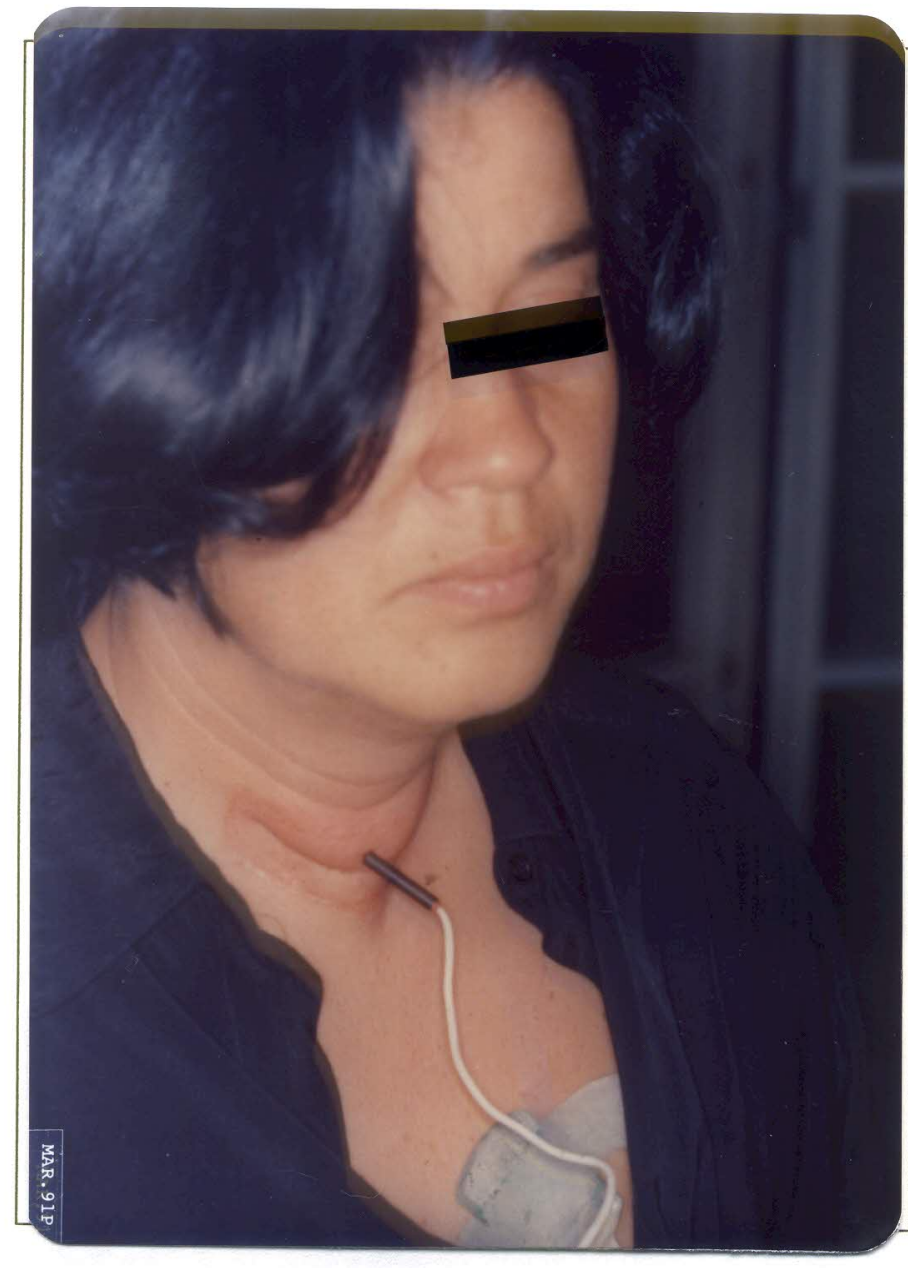

Figura 3.18 -

Eletromiografia pós-operatória; o eletrodo está sendo dirigido para o MCT direito.

\section{MCTE - NORMAL}

Figura 3.19 -

Traçado

eletromiográfico de um MCT normal, mostrando um evidente aumento da atividade elétrica ao se produzir um "i" agudo (seta).

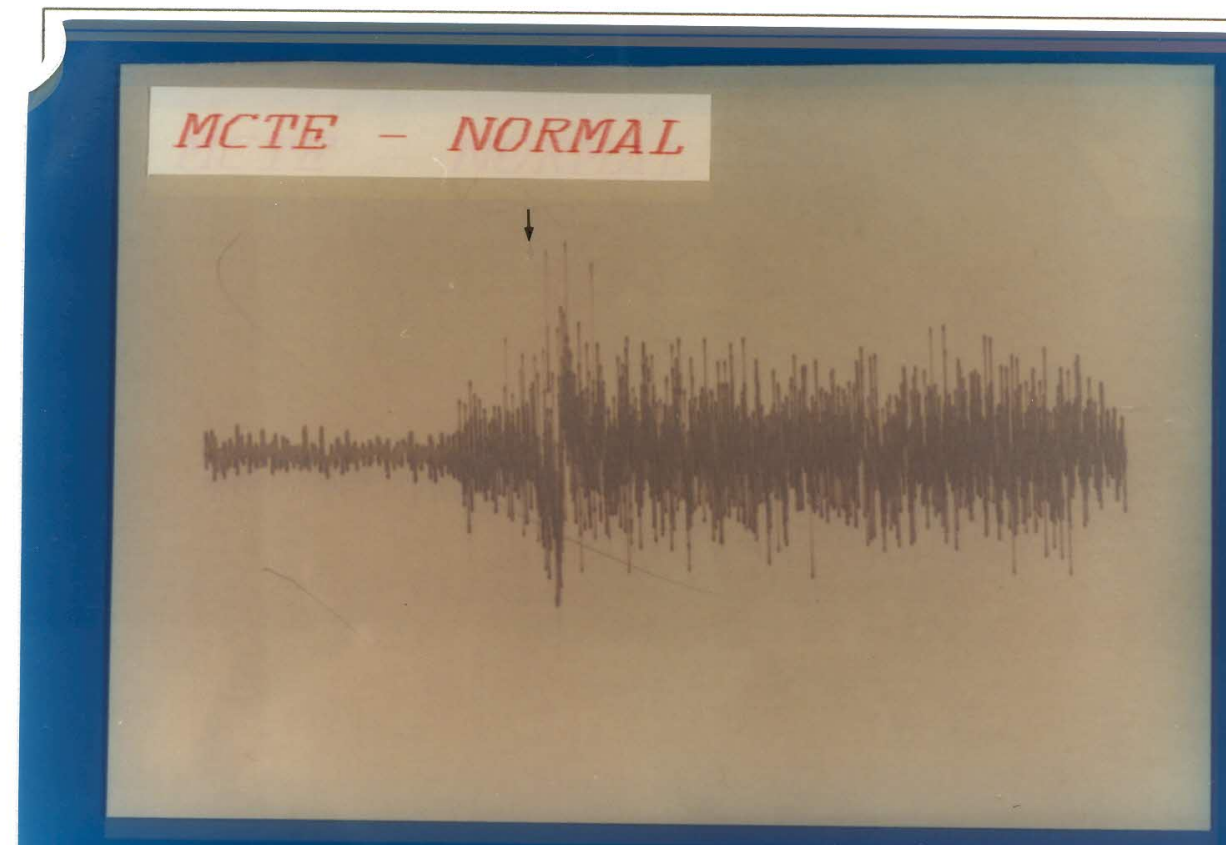




\section{MCTE - SEM ATIVIDADE}

Figura 3.20 -

"Silêncio elétrico", fruto de uma lesão completa do RELS esquerdo; o discreto

aumento da atividade elétrica de fundo é conferido pela ação do restante da musculatura intrínseca da laringe.
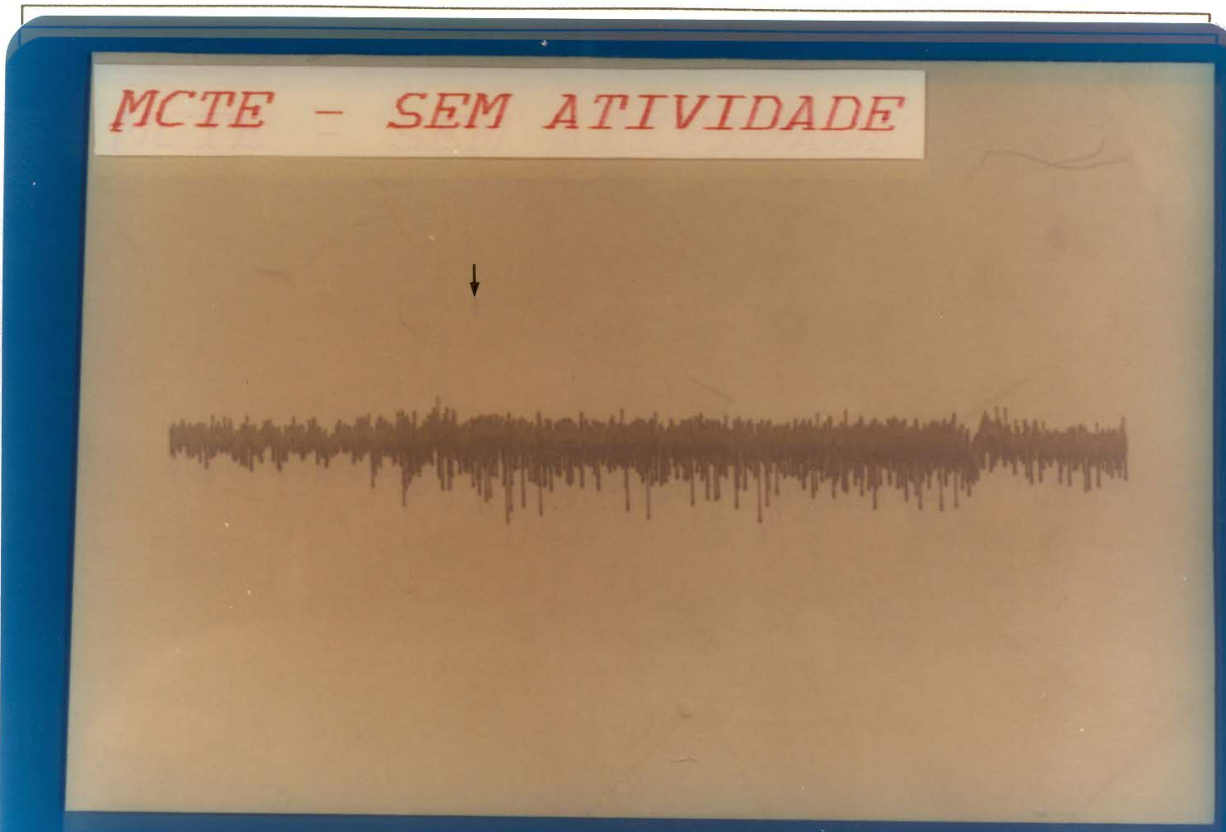

MAR. 91

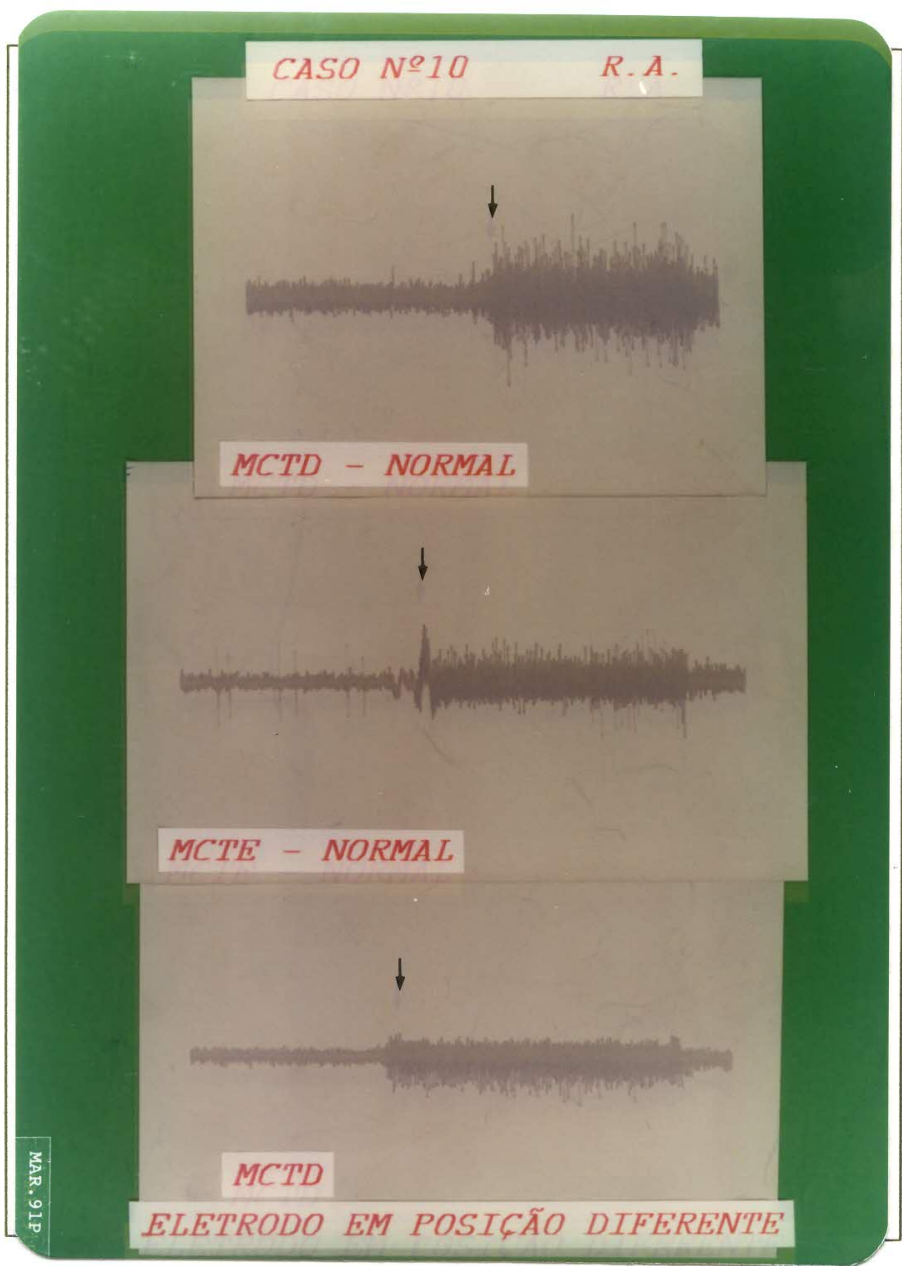

Figura 3.21 -

Estudo eletromiográfico de uma paciente com atividade normal em ambos os MCTs; entretanto, após a execução da análise do músculo esquerdo, repetiu-se o estudo à direita, pela mesma punção cutânea, resultando num traçado elétrico bastante diferente. 


\subsubsection{AVALIAÇÃO PÓS-OPERATÓRIA TARDIA}

Os doentes que sofreram uma paralisia pós-operatória do RELS foram submetidos a uma outra avaliação fonoaudiológica, acompanhada de uma nova eletromiografia, seis meses após a cirurgia. Os casos em que se comprovou a persistência das alterações foram considerados como portadores de paralisia definitiva.

\subsubsection{ANÁLISE ESTATÍSTICA E EDIÇÃO}

Os dados obtidos foram inseridos num microcomputador PC-XT (IBM comp., 12 $\mathrm{MHz}, 1 \mathrm{Mb}$ RAM; proc.: NEC V20), através de um programa "D-BASE III plus" (Ashton-Tate, USA, 1986) para armazenamento de dados e submetidos à análise estatística por intermédio de um programa SPSS/PC (SSPSS inc., Illinois, USA), que aplicou os testes: Chi quadrado, "Student's exact test", teste de Fisher, análise de variância e tabelas de contingência, consoante as necessidades de cada avaliação. A confecção do banco de dados foi feita pelo próprio Autor, ao passo que a análise estatística foi executada pela Dra. Lourdes A. Marques, no Instituto Ludwig de Pesquisa sobre o Câncer. O Estudo estatístico foi verificado pelo Prof. Dr. Ruy Geraldo Bevilacqua e acrescido, quando indicado, de uma análise multivariada, usando um programa MULTLR (Multiple Logistic Regression by Unconditional and Conditional Methods, Ludwig Institute for Cancer Research, SP Branch, 1988).

O texto foi editado no mesmo microcomputador, por meio de um programa "WORD 4" (Microsoft Corporation, USA, 1987), bem como as figuras, tabelas e gráficos, produzidos com o auxílio de um programa "HARVARD GRAPHICS" (Software Publishing Corp., USA, 1987). A versão final foi preparada por meio de um microcomputador PC-Brand, modelo AT/386-25 (PC Brand, Inc.; $25 \mathrm{MHz}$; 6,5 Mb RAM; proc.: Intel 80386-25), utilizando os programas Ventura (Xerox Corporation, USA, 1990), para diagramação, Graph Plus (Micrografx, USA, 1990), para gráficos, e Picture Publisher (Micrografx, USA, 1990), para reprodução de ilustrações. Foram utilizados, ainda, um digitalizador de página inteira Scanjet Plus (Hewlett Packard, USA, 1989) e uma impressora a laser LaserJet series II (Hewlett Packard, USA, 1988).

\subsubsection{CRITÉRIOS DE EXCLUSÃO E FORMAÇÃO DEFINITIVA DOS GRUPOS}

No período compreendido entre Fevereiro de 1989 e Junho de 1990, 103 doentes que reuniam os pré-requisitos necessários concordaram em ingressar no protocolo de estudo. Dentre eles, 27 foram excluídos pelos motivos abaixo relacionados:

a) exclusões antes da cirurgia - apesar de teram sido submetidos à avaliação completa pré-operatória, 16 pacientes não foram operados, ou porque mudaram de idéia quanto ao tratamento (4 casos), ou por não comparecerem aos retornos nem serem passíveis de localização nos endereços e/ou telefones por eles próprios fornecidos (12 casos). 
b) exclusões durante a cirurgia - para não colocar em risco a uniformidade dos grupos de estudo, foram afastados aqueles pacientes nos quais, pelas mais diversas razões, a conduta operatória adotada contribuiu para adicionar ou suprimir tempos que poderiam, eventualmente, influir nos resultados finais. Assim, em dois casos, a cirurgia consistiu apenas numa istmectomia, enquanto que um esvaziamento ganglionar cervical funcional e uma exérese de um cisto tireoglosso foram executados, respectivamente, em um doente cada. Em uma paciente, que foi reoperada 14 dias após a primeira cirurgia para a totalização da tireoidectomia, pela constatação de um carcinoma folicular ao exame de parafina, encontrou-se uma fibrose tal que dificultava ao extremo a identificação das estruturas anatômicas adjacentes à glândula tireóide. Finalmente, em um caso, houve uma secção intra-operatória não intencional do nervo recorrente que, reconhecida de imediato, foi prontamente tratada pela anastomose término-terminal com fio 7-0 inabsorvivel. Foram, portanto, preteridos 6 pacientes, ainda em meio ao ato operatóric.

c) exclusōes após a cirurgia - um doente exibiu, à laringoscopia indireta pós-operatória, uma paralisia unilateral de prega vocal. Apesar de ter havido uma regressão completa,com recuperação funcional após 5 meses, a avaliação pós-operatória da voz não foi completada. Quatro outros pacientes não retornaram: dois não foram localizados e outros dois não quiseram se submeter à eletromiografia precoce. Assim, 5 doentes foram excluídos do estudo após a cirurgia.

Setenta e seis indivíduos completaram a sequência proposta no protocolo e constituem a base do presente estudo. O Grupo 1 incluiu 26 casos, ao passo que os outros dois tiveram 25 pacientes cada. 


\section{RESULTADOS}

\subsection{RESULTADOS OBTIDOS À AVALIAÇÃO FONOAUDIOLÓGICA PRÉ- OPERATÓRIA}

A análise dos dados obtidos à avaliação fonoaudiológica pré-operatória dos três grupos evidenciou um Ig médio mais grave no Grupo 3 em relação aos outros $(\mathrm{p}=0,0308)$. Além disso, a CPFA também foi significativamente maior neste grupo $(p=0,016)$. Os demais parâmetros avaliados não demonstraram diferenças estatisticamente significativas (Tab. 4.1). Já que o aspecto mais importante da análise final dos resultados da avaliação fonoaudiológica foi, como veremos mais adiante, a comparação entre os respectivos valores pré e pós operatórios, dentro de cada grupo e entre eles, estas discrepâncias no tocante ao Ig pré-operatório e à CPFA foram consideradas de importância menor no universo de dados coletados.

\subsection{RESULTADOS OBTIDOS À AVALIAÇÃO FONOAUDIOLÓGICA PÓS- OPERATÓRIA IMEDIATA}

Os dados obtidos à avaliação fonoaudiológica pós-operatória imediata foram comparados com os respectivos dados pré-operatórios, em cada grupo. A análise estatística foi aplicada aos dados de cada grupo, isoladamente.

Os doentes do Grupo 1 exibiram uma performance vocal nitidamente superior após a cirurgia, traduzida por uma melhora nos parâmetros aferidos (Tab. 4.2). Em alguns dos itens avaliados, tais como: $\operatorname{Taf}(p=0,034), \mathrm{TFa}(p=0,040)$, TFs $(p=0,034), \operatorname{TFz}(p=0,042)$ e CPFA $(p=0,029)$, esta melhora foi estatisticamente significativa. No tocante às freqüências vocais, não houve alteração significativa. 
TABELA 4.1

AVALIAÇÃO FONAUDIOLÓGICA PRÉ-OPERATÓRIA

\begin{tabular}{ccccc}
\hline & Grupo I & Grupo 2 & Grupo 3 & $p$ \\
\hline Ig (cps) & $\mathbf{1 9 1}$ & $\mathbf{1 9 5}$ & $\mathbf{1 7 1}$ & $\mathbf{0 , 0 3 0 8}$ \\
I (cps) & 219 & 222 & 205 & 0,1965 \\
Ia (cps) & 575 & 564 & 628 & 0,2176 \\
Iag (cps) & 384 & 369 & 457 & 0,0543 \\
& & & & \\
Taf (s) & 8 & 8 & 9 & 0,5670 \\
TFa (s) & 12 & 13 & 12 & 0,6795 \\
TFi (s) & 14 & 15 & 14 & 0,5431 \\
TFs (s) & 13 & 15 & 13 & 0,4116 \\
TFz (s) & 12 & 13 & 12 & 0,4475 \\
CPFA & $\mathbf{1 1}$ & $\mathbf{1 1}$ & $\mathbf{1 4}$ & $\mathbf{0 , 0 0 1 6}$ \\
\hline
\end{tabular}

TABELA 4.2

AVALIAÇÃO FONOAUDIOLÓGICA PRÉ E PÓS-OPERATÓRIA IMEDIATA - GRUPO 1 -

\begin{tabular}{cccc}
\hline & $\begin{array}{c}\text { Avaliação } \\
\text { Fonoaudiológica } \\
\text { Pré-Operatória }\end{array}$ & $\begin{array}{c}\text { Avaliação } \\
\text { Fonoaudiológica } \\
\text { Pós-Operatória }\end{array}$ & $p$ \\
\cline { 2 - 4 } Ig (cps) & 191 & 189 & 0,064 \\
I (cps) & 219 & 220 & 0,7371 \\
Ia (cps) & 575 & 588 & 0,520 \\
Iga (cps) & 384 & 400 & 0,471 \\
& & & \\
Taf (s) & $\mathbf{8}$ & $\mathbf{1 0}$ & $\mathbf{0 , 0 3 4}$ \\
TFa (s) & $\mathbf{1 2}$ & $\mathbf{1 4}$ & $\mathbf{0 , 0 4 0}$ \\
TFi (s) & 14 & 15 & 0,522 \\
TFs (s) & $\mathbf{1 3}$ & $\mathbf{1 7}$ & $\mathbf{0 , 0 3 4}$ \\
TFz (s) & $\mathbf{1 2}$ & $\mathbf{1 4}$ & $\mathbf{0 , 0 4 2}$ \\
CPFA & $\mathbf{1 1}$ & $\mathbf{1 2}$ & $\mathbf{0 , 0 2 9}$ \\
\hline
\end{tabular}


No Grupo 2, por outro lado, ocorreu uma piora da performance vocal, evidenciada na Tabela 4.3. Constataram-se aqui quedas na freqüência do $\operatorname{Ig}(p=0,024)$ e do $\operatorname{Ia}(p=0,027)$, além de uma redução na extensão vocal $(p=0,044)$, todas significativas. Quanto aos outros parâmetros, alguns melhoraram, ao passo que outros praticamente não variaram; nenhuma destas últimas alterações, contudo, teve peso estatístico.

As mudanças nas mensurações efetuadas no Grupo 3 podem ser avaliadas na Tabela 4.4. Foram dignas de nota a profunda queda na freqüência do Ia $(\mathrm{p}<0001)$ e a marcante redução na extensão vocal $(\mathrm{p}<0001)$ verificadas nos indivíduos deste grupo. As outras freqüências vocais (I e Ig) também pioraram, porém não houve significância estatística. Os outros parâmetros avaliados melhoraram, com exceção da CPFA, embora estas alterações também não se revestissem de significado estatístico.

\section{TABELA 4.3 \\ AVALIAÇÃO FONOAUDIOLÓGICA PRÉ E PÓS-OPERATÓRIA IMEDIATA - GRUPO 2 -}

\begin{tabular}{|c|c|c|c|}
\hline & $\begin{array}{c}\text { Avaliação Fonoaudiológica } \\
\text { Pré-Operatória }\end{array}$ & $\begin{array}{c}\text { Avaliação Fonoaudiológica } \\
\text { Pós-Operatória }\end{array}$ & $p$ \\
\hline Ig (cps) & 196 & 186 & 0,024 \\
\hline $\mathrm{I}(\mathrm{cps})$ & 223 & 217 & 0,399 \\
\hline Ia (cps) & 565 & 502 & 0,027 \\
\hline Iga (cps) & 369 & 316 & 0,044 \\
\hline $\operatorname{Taf}(\mathrm{s})$ & 8 & 9 & 0,172 \\
\hline $\mathrm{TFa}(\mathrm{s})$ & 13 & 14 & 0,528 \\
\hline TFi (s) & 16 & 16 & 0,741 \\
\hline TFs (s) & 16 & 16 & 0,798 \\
\hline $\mathrm{TFz}(\mathrm{s})$ & 14 & 14 & 0,706 \\
\hline \multicolumn{4}{|c|}{$\begin{array}{c}\text { TABELA } 4.4 \\
\text { AVALIAÇÃO FONOAUDIOLÓGICA PRÉ E PÓS-OPERATÓRIA IMEDIATA } \\
\text { - GRUPO } 3 \text { - }\end{array}$} \\
\hline & $\begin{array}{c}\text { Avaliação Fonoaudiológica } \\
\text { Pré-Operatória }\end{array}$ & $\begin{array}{c}\text { Avaliação Fonoaudiológica } \\
\text { Pós-Operatória }\end{array}$ & $p$ \\
\hline $\operatorname{Ig}(\mathrm{cps})$ & 172 & 168 & 0,342 \\
\hline $\mathrm{I}(\mathrm{cps})$ & 205 & 204 & 0,830 \\
\hline Ia (cps) & 629 & 518 & $<0,0001$ \\
\hline Iga (cps) & 457 & 350 & $<0,0001$ \\
\hline $\operatorname{Taf}(\mathrm{s})$ & 9 & 10 & 0,477 \\
\hline $\mathrm{TFa}(\mathrm{s})$ & 12 & 13 & 0,603 \\
\hline TFi (s) & 14 & 16 & 0,319 \\
\hline TFs (s) & 15 & 16 & 0,410 \\
\hline TFz (s) & 12 & 13 & 0,839 \\
\hline
\end{tabular}




\subsection{RESULTADOS OBTIDOS À AVALIAÇÃO ELETROMIOGRÁFICA PÓS- OPERATÓRIA PRECOCE}

O parâmetro considerado como mais importante para a comprovação da lesão completa do RELS foi a ausência de atividade eletromiográfica do MCT. Dentre os doentes do Grupo 1, nenhum exibiu esta lesão nervosa, ao passo que ela foi observada em $7(28 \%)$ dos indivíduos do Grupo 2 e em 3 (12\%) dos casos do Grupo 3, na avaliação pós-operatória precoce (Fig. 4.1). Utilizandose o teste do Chi-quadrado para uma análise estatística global dos 3 grupos, notou-se uma diferença significativa $(p=0,0123)$. Comparando-se os Grupos 1 e 2 através do teste de Fisher, obteve-se uma diferença bastante significativa ( $\mathrm{p}=0,0041520)$. Já ao se cotejarem os Grupos 1 e 3, não houve significância estatística ( $\mathrm{p}=0,1104442)$. Da mesma forma, quando estudados os resultados dos Grupos 2 e 3, não se notou significado estatístico $(\mathrm{p}=0,2890159)$.

Levando-se em conta os RELSs submetidos ao risco de lesão iatrogênica em relação aos grupos de estudo, verificou-se que eles totalizaram 28 nervos no Grupo 1, 31 no Grupo 2 e 31 no Grupo 3, respectivamente. Estes nervos foram comparados com o Grupo denominado 4, composto de 62 RELSs não dissecados, aplicando-se o teste de Fisher. Evidentemente, não houve qualquer diferença entre os Grupos 1 e 4, já que em nenhum deles apareceu qualquer caso de lesão total do RELS. Por outro lado, ao se cotejarem os resultados dos Grupos 2 e 3 com o 4, notaram-se diferenças estatisticamente significativas em ambas as comparações ( $p=0,0002776$ e $p=0,0346393$, respectivamente). Uma comparação entre estes quatro contingentes pode ser mais claramente visualizada na Figura 4.2.

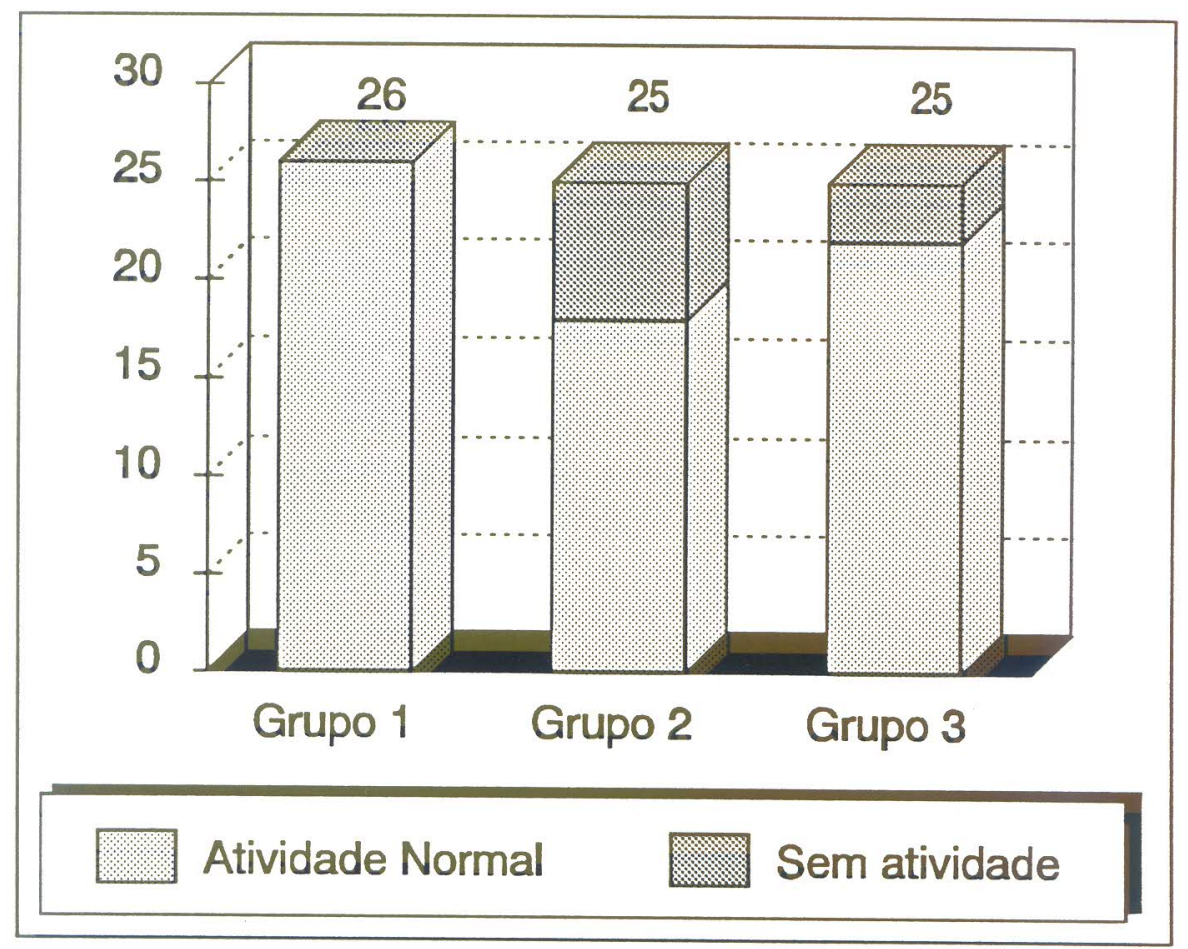

Figura 4.1 - EMG Precoce do MCT 


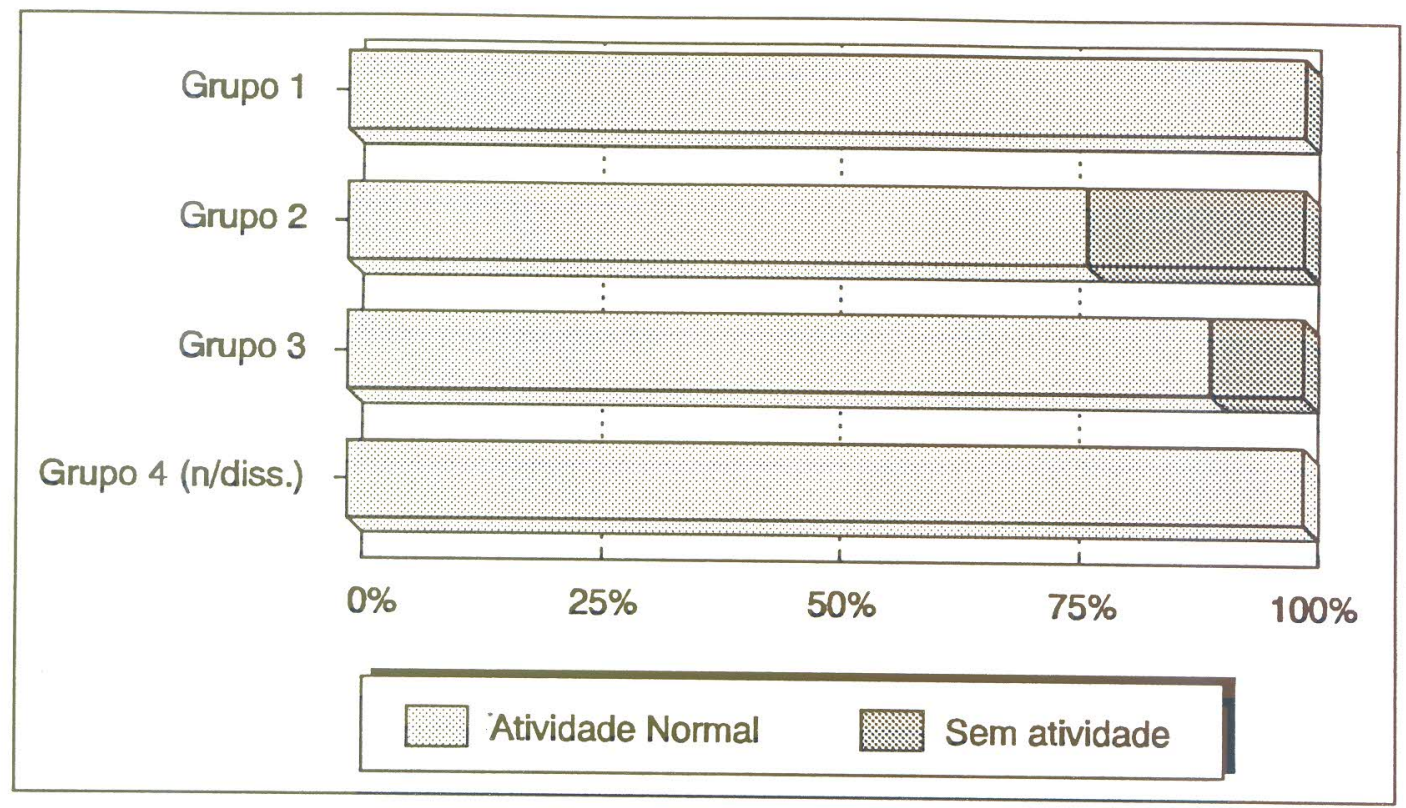

Figura 4.2 - EMG Precoce do MCT - Análise para Polos Superiores

\subsection{RESULTADOS OBTIDOS À AVALIAÇÃO FONOAUDIOLÓGICA PÓS-OPE- RATÓRIA TARDIA}

Como não se constataram casos de lesão total do RELS no Grupo 1, as avaliações tardias não foram efetuadas neste grupo.

Uma das doentes do Grupo 2 não compareceu para a avlaliação fonoaudiológica pósoperatória tardia, apesar de ter se submetido à eletromiografia tardia, na qual foi comprovada uma lesão definitiva. Assim, foram analisados os dados fonoaudiológicos concernentes aos restantes seis indivíduos deste grupo que haviam mostrado uma lesão completa do RELS à eletromiografia precoce.

Uma comparação dos valores obtidos com os correspondentes pré-operatórios, entre os indivíduos do Grupo 2, pode ser observada na Tabela 4.5. Nota-se que, dentre os parâmetros que mediram a freqüência vocal, o Ig $(p=0,049)$ e o I $(p=0,050)$ situaram-se num patamar significativamente mais baixo, enquanto que o Ia, apesar de continuar mais grave, passou a não diferir significativamente dos valores anotados antes da operação $(p=0,367)$. A extensão vocal, apesar de continuar inferior à pré-operatória, passou a não diferir de forma importante, sob o aspecto estatístico. Quanto às outras variáveis, as alterações não foram significativas, apesar de se observar uma nítida piora, já que todos os valores pós-operatórios se mostraram inferiores aos respectivos pré-operatórios.

No Grupo 3, um dos pacientes não compareceu às avaliações tardias, restando portanto dois indivíduos, cujos resultados também foram cotejados com os valores pré-operatórios (Tab. 4.6). Constatou-se apenas uma piora no TFs de importância estatística $(p=0,006)$. Deve-se aqui ressalvar, contudo, a precariedade de uma análise mais profunda com um número tão reduzido de observações. 
TABELA 4.5

AVALIAÇÃO FONOAUDIOLÓGICA PRÉ E PÓS-OPERATÓRIA TARDIA - GRUPO 2 -

\begin{tabular}{cccc}
\hline & $\begin{array}{c}\text { Avaliação } \\
\text { Fonoaudiológica } \\
\text { Pré-Operatória }\end{array}$ & $\begin{array}{c}\text { Avaliação } \\
\text { Fonoaudiológica } \\
\text { Pós-Operatória }\end{array}$ & $p$ \\
\cline { 2 - 4 } Ig (cps) & $\mathbf{1 9 9}$ & $\mathbf{1 8 4}$ & $\mathbf{0 , 0 4 9}$ \\
I (cps) & 237 & $\mathbf{2 0 7}$ & $\mathbf{0 , 0 5 0}$ \\
Ia (cps) & 560 & 483 & 0,367 \\
Iga (cps) & 361 & 299 & 0,448 \\
& & & \\
Taf (s) & 10 & 9 & 0,787 \\
TFa (s) & 14 & 12 & 0,328 \\
TFi (s) & 15 & 14 & 0,387 \\
TFs (s) & 16 & 12 & 0,351 \\
TFz (s) & 14 & 10 & 0,550 \\
CPFA & 13 & & 0,305 \\
\hline
\end{tabular}

TABELA 4.6

AVALIAÇÃO FONOAUDIOLÓGICA PRÉ E PÓS-OPERATÓRIA TARDIA - GRUPO 3 -

\begin{tabular}{cccc}
\hline & $\begin{array}{c}\text { Avaliação } \\
\text { Fonoaudiológica } \\
\text { Pré-Operatória }\end{array}$ & $\begin{array}{c}\text { Avaliação } \\
\text { Fonoaudiológica } \\
\text { Pós-Operatória }\end{array}$ & $\boldsymbol{p}$ \\
\cline { 2 - 4 } Ig (cps) & 146 & 149 & 0,677 \\
I (cps) & 170 & 169 & 0,895 \\
Ia (cps) & 570 & 722 & 0,463 \\
Iga (cps) & 424 & 573 & 0,478 \\
& & & \\
Taf (s) & 8 & 7 & 0,500 \\
TFa (s) & 7 & 10 & 0,500 \\
TFi (s) & 11 & 13 & 0,500 \\
TFs (s) & 14 & $\mathbf{1 1}$ & $\mathbf{0 , 0 0 6}$ \\
TFz (s) & 9 & 12 & 0,590 \\
CPFA & 12 & 13 & 0,205 \\
\hline
\end{tabular}




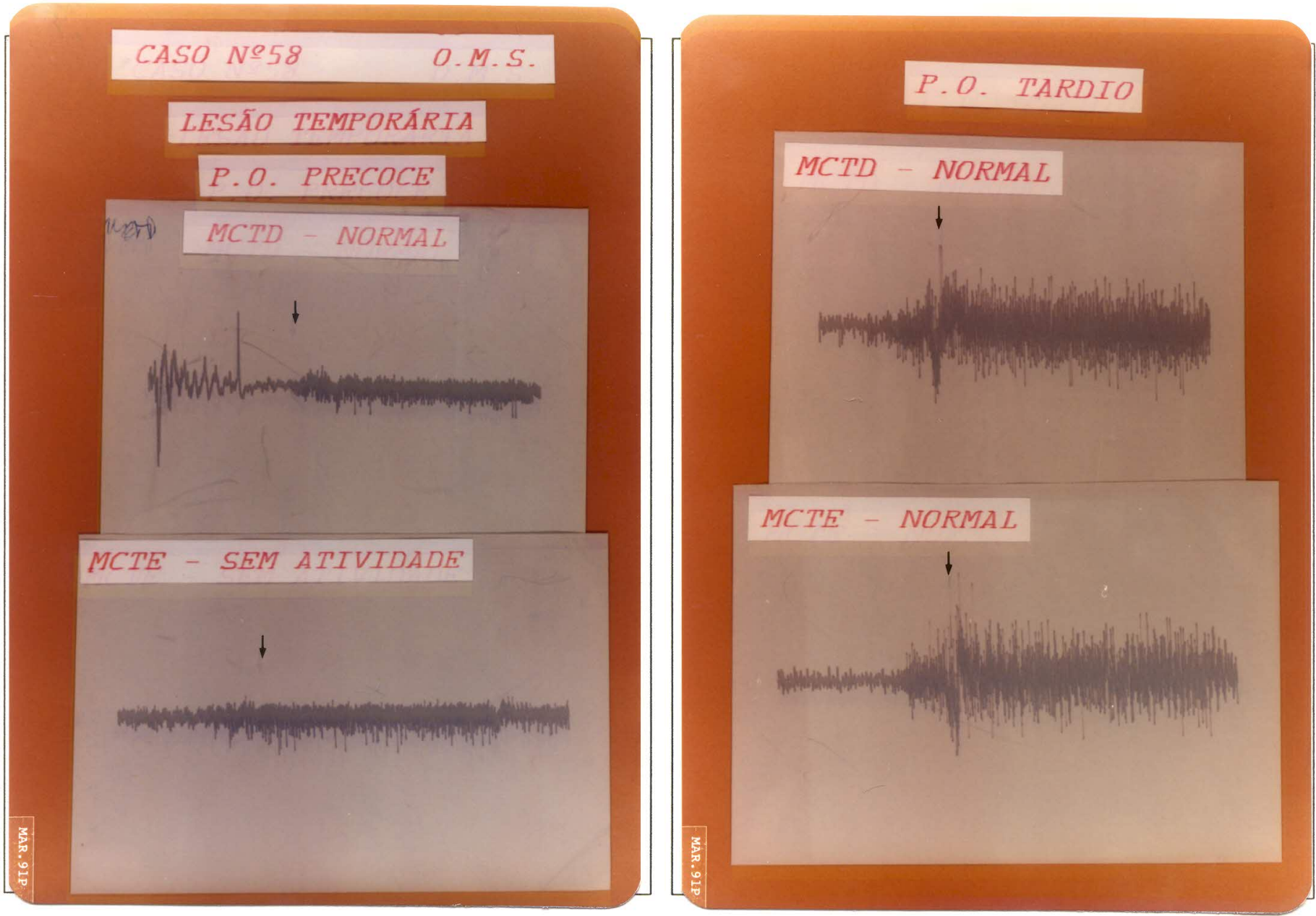

Figura 4.4

Paciente com lesão completa temporária do MCT esquerdo. Na sequência situada à esquerda, é evidente uma ausência de atividade elétrica no músculo esquerdo; ao contrário do que ocorreu no caso demonstrado na figura anterior, porém, observa-se, na sequência da direita, uma completa recuperação funcional do referido músculo. 


\subsection{COMPARAÇÃO ENTRE OS RESULTADOS OBTIDOS COM A AVALIA- ÇÃO ELETROMIOGRÁFICA E OS DADOS DO ESTUDO CLÍNICO}

Os dados do estudo clínico foram comparados, através de uma análise estatística, com os resultados obtidos com a avaliação pós-operatória precoce (Tabela 4.7). Além dos diferentes grupos do estudo, que apresentaram, como já vimos, uma incidência significativamente diferente de lesões totais do RELS, apenas a cor do paciente apresentou uma influência estatisticamente significativa $(p=0,001)$ quando testada tanto pelo teste de Fisher quanto pela análise multivariada. A incidência de lesão entre os pacientes não brancos foi de $41 \%$, enquanto que apenas $5 \%$ dos brancos a apresentaram.

TABELA 4.7

DADOS DO ESTUDO CLÍNICO $X$ EMG PRECOCE

\begin{tabular}{cc} 
Grupo & $\mathbf{p}=\mathbf{0 , 0 1 2}$ \\
Sexo & $\mathrm{p}=1,000$ \\
Cor & $\mathbf{p}=\mathbf{0 , 0 0 1}$ \\
Compr. traq. & $\mathrm{p}=0,484$ \\
Desvio traq. & $\mathrm{p}=0,721$ \\
Tir. parc./tot. & $\mathrm{p}=0,985$ \\
Tu ben./mal. & $\mathrm{p}=0,989$ \\
\hline
\end{tabular}

\subsection{COMPARAÇÃO ENTRE OS RESULTADOS OBTIDOS COM AS AVALIA- ÇÕES FONOAUDIOLÓGICA E ELETROMIOGRÁFICA}

Foi feita uma comparação estatística entre os dados obtidos com a eletromiografia pós-operatória precoce do MCT e aqueles observados à avaliação fonoaudiológica pós-operatória imediata, demonstrada na Tabela 4.8. Destacaram-se a correlação entre a lesão completa do RELS e a queda da freqüência fundamental $(p=0,0295)$ e a forte associação entre esta lesão e a queda das freqüências mais agudas ( $p<0001$ ). Houve também uma diminuição altamente significativa da extensão vocal nos indivíduos que apresentaram uma lesão completa do RELS ( $\mathrm{p}<0001)$. Além destes parâmetros, o TFz foi o único a diminuir significativamente quando ocorreu uma lesão completa do RELS $(p=0,0129)$. 
TABELA 4.8

AVALIAÇÃO FONOAUDIOLÓGICA PÓS-OPERATÓRIA IMEDIATA $X$ EMG PRECOCE

\begin{tabular}{cc}
\hline Ig & $\mathrm{p}=0,2609$ \\
I & $\mathbf{p}=\mathbf{0 , 0 2 9 5}$ \\
Ia & $\mathbf{p}<\mathbf{0 , 0 0 0 1}$ \\
Iga & $\mathbf{p}<\mathbf{0 , 0 0 0 1}$ \\
& \\
TAf & $\mathrm{p}=0,2697$ \\
TFa & $\mathrm{p}=0,4236$ \\
TFi & $\mathrm{p}=0,0973$ \\
TFs & $\mathrm{p}=0,0924$ \\
TFz & $\mathbf{p}=\mathbf{0 , 0 1 2 9}$ \\
CPFA & $\mathrm{p}=0,0624$ \\
\hline
\end{tabular}

Na comparação estatística entre a eletromiografia pós-operatória tardia do MCT e os achados da avaliação fonoaudiológica pós-operatória tardia, não se observou correlaçào significativa entre qualquer dos parâmetros e a lesão completa do RELS (Tab. 4.9). Entretanto, deve-se ressaltar que, além do reduzido número de casos com lesão definitiva, um deles foi descartado desta análise por não se ter submetido à avaliação fonoaudiológica tardia.

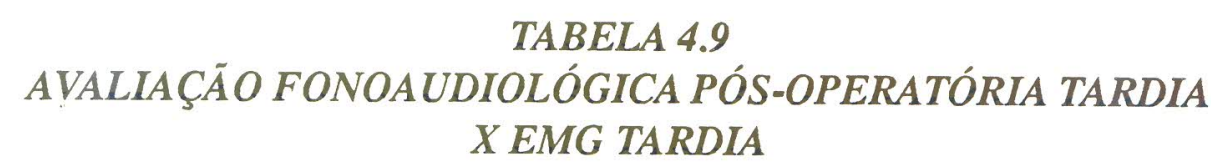

\begin{tabular}{cl}
\hline Ig & $\mathrm{p}=0,9688$ \\
I & $\mathrm{p}=0,7227$ \\
Ia & $\mathrm{p}=0,0652$ \\
Iga & $\mathrm{p}=0,0951$ \\
& \\
TAf & $\mathrm{p}=0,2480$ \\
TFa & $\mathrm{p}=0,2706$ \\
TFi & $\mathrm{p}=0,3728$ \\
TFs & $\mathrm{p}=0,9605$ \\
TFz & $\mathrm{p}=0,3462$ \\
CPFA & $\mathrm{p}=0,0906$ \\
\hline
\end{tabular}




\section{DISCUSSÃO}

As operações sobre a glândula tireóide eram, até fỉns do século passado, procedimentos arriscados e perigosos, conforme atestavam os depoimentos de vários autores ${ }^{22,109}$. Após a extraordinária contribuição de $\mathrm{KOCHER}^{36,88}$, contudo, as tireoidectomias passaram a obedecer a uma padronização técnica quase que universalmente aceita e, paralelamente, a se acompanhar de um grau de morbidade bastante reduzido $154,116,65,3,94,59,125,47,71,83,170,138,148,48$. As complicações mais focalizadas por quase todas as publicações disponíveis sempre foram as lesões do nervos recorrentes e das glândulas paratireóides. Alguns autores, no entanto, já alertavam para a possibilidade de lesão do RELS durante a ligadura do pedículo superior tireoideano desde primórdios deste sécu$10132,12,4,46,47,24,82,26,99,77$. Outros, porém, admitiam uma enorme dificuldade para se comprovar esta lesão, pelos poucos sintomas e pelas sutis alterações laringoscópicas que acarretava $166,60,74,32,87,36$.

Ainda assim, causava estranheza a escassez, na literatura internacional, de publicações avaliando, de forma científicamente clara, a real incidência da lesão iatrogênica do RELS no decurso de uma tireoidectomia ${ }^{99,77}$ ou propondo formas de identificar o nervo, tornando menos provável a sua lesão $38,90,82,55,101,56$.

Surgiu assim a motivação para se empreender um estudo prospectivo, duplo cego e randomizado, que procurasse aquilatar não só a real incidência desta complicação num Serviço universitário especializado em Cirurgia de Cabeça e Pescoço como também avaliar o eventual benefício da identificação intra-operatória do RELS para a profilaxia da sua lesão.

$\mathrm{Na}$ primeira parte desta tese, foi efetuado um estudo anatômico em 15 cadáveres, totalizando portanto 30 polos tireoideanos superiores analisados. A classificação proposta, revestida de um cunho eminentemente prático, mostrou que os nervos do tipo 2, que totalizaram $37 \%$, poderiam apresentar, em teoria, um risco maior de sofrerem uma lesão iatrogênica. Mais importante, todavia, foi a constatação que $20 \%$ destes nervos eram do tipo $2 b$, ou seja, situavam-se abaixo do plano horizontal que passava pela borda do polo superior da glândula tireóide, configurando destarte uma situa- 
ção de extremo perigo e facilitando a sua inclusão na ligadura do pedículo tireoideano superior, mormente se o cirurgião não fosse muito afeito à cirurgia tireoideana. Ao compararmos esta incidência de RELSs de "alto risco" com outras publicações (Tab. 5.1), podemos constatar que, apesar dos diversos critérios de risco adotados nos diferentes estudos, a chance potencial de lesão iatrogênica do RELS oscila entre 15 e $65 \%$, não sendo, portanto, desprezível. Dentre estes estudos anatômicos, sobressai aquele feito por ESPINOZA e $\mathrm{col}^{40}$, por ser o único em que se procurou reproduzir as condições técnicas de uma tireoidectomia, chegando a uma freqüência de lesão do nervo de $15 \%$. Talvez esta seja a que mais se aproxime da realidade.

TABELA 5.1

RELS DE "ALTO RISCO"-ESTUDOS ANATÔMICOS

\begin{tabular}{ccc}
\hline Autor/Ano & Dissecçöes & $\%$ \\
\hline BARROS (10), 1948 & 60 & 21 \\
CLADER (25), 1957 & 96 & 68 \\
DURHAM (35), 1964 & 100 & 25 \\
MOOSMAN (113), 1968 & 400 & 21 \\
ESPINOZA (40), 1989 & 30 & 15 \\
LENNQUIST (101), 1989 & 50 & 18 \\
Presente estudo & & \\
\hline
\end{tabular}

Em contrapartida, por vezes o RELS se encontra naturalmente protegido contra lesões iatrogênicas durante manipulações cirúrgicas do polo superior tireoideano, por assumir uma posição mais alta do que o habitual, ou então por adotar um trajeto localizado na intimidade das fibras do músculo constritor inferior da faringe. Na classificação proposta no presente estudo, esta primeira variação anatômica corresponderia ao nervo não identificado. Provavelmente, na única dissecção desta série na qual o nervo não foi identificado, sendo, portanto, incluído nesta categoria (3\%), o seu trajeto era tão alto que não ofereceria risco durante uma tireoidectomia. Já a segunda configuração foi notada em $11 \%$ das dissecções feitas por MOOSMAN \& DE WEESE ${ }^{113}$ e em $20 \%$ por LENNQUIST e col. ${ }^{101}$. Dentre os 18 nervos do Tipo 1 observados em nosso estudo, 5 (28\%) se encontravam em meio às fibras do referido músculo e, portanto, protegidos durante uma hipotética tireoidectomia.

Um aspecto interessante foi a assimetria entre as características dos dois RELSs, constatada em 53\% dos cadáveres dissecados. Assim, durante tireoidectomias bilaterais, o risco teórico de lesão não seria necessariamente o mesmo para os dois polos superiores.

A presença de uma tireoidopatia, observada em $28 \%$ dos cadáveres, não interferiu significativamente na posição do RELS em relação ao correspondente pedículo superior-tireoideano. É fato, contudo, que não encontramos nenhum caso, entre os cadáveres, de bócio de grandes dimensões. VERNETTI ${ }^{155}$ chamou a atenção para o fato de que a elevação do polo superior tireoideano pela pre- 
sença de nódulos deformava os vasos tireoideanos superiores, juntando-os ao nervo. MENASCHE e col. $^{112}$ encontraram o RELS intimamente aderido à glândula em 6 dissecções, três das quais em doentes que apresentavam bócios.

Na segunda parte deste estudo, foram analisados 76 pacientes submetidos a tireoidectomias uni ou bilaterais, que colocassem em risco pelo menos um RELS. As exclusões durante o ato operatório foram efetuadas visando a preservar a uniformidade da conduta terapêutica nos três grupos, possibilitando uma comparação mais fidedigna. Assim, enquanto que em dois casos a cirurgia consistiu apenas numa istmectomia, não ameaçando portanto a integridade de nenhum nervo, em outros dois, além da tireoidectomia, foram feitos um esvaziamento ganglionar cervical modificado e uma exérese de um cisto do ducto tireoglosso, adicionando, pelo menos em teoria, um risco suplementar para o nervo ou para estruturas relacionadas com a fonação. Analogamente, os dois pacientes que exibiram uma lesão do nervo recorrente também foram retirados do estudo, pois a intensa disfonia interferiria acentuadamente na avaliação fonoaudiológica pós-operatória. Dentre estes dois casos, mesmo o que apresentou uma paralisia temporária só recuperou totalmente a mobilidade da prega vocal 5 meses após a cirurgia; estaríamos, portanto, comprometendo a homogeneidade da metodologia se, só então, realizássemos a primeira avaliação fonoaudiológica.

Em relação ao perfil da casuística, a proporção entre doentes dos sexos feminino e masculino (7,4:1) mostrou-se compatível com a distribuição na incidência das tireoidopatias em relação ao sexo observada na DCCP-HC FMUSP (9:1).

Os três grupos se mostraram bastante comparáveis, no tocante às características de seus indivíduos (Figs. 5.1, 5.2 e 5.3). As discrepâncias encontradas à avaliação fonaudiológica préoperatória, em relação aos parâmetros Ig e CPFA, apesar de frutos do acaso inerente a qualquer seleção aleatória, devem ser aqui ressaltadas. Parece-nos, porém, que a sua importância foi minimizada pelo fato de se considerar a variação entre os respectivos parâmetros pré e pós-operatórios dentro de cada grupo como $o$ aspecto mais importante para a avaliação estatística.

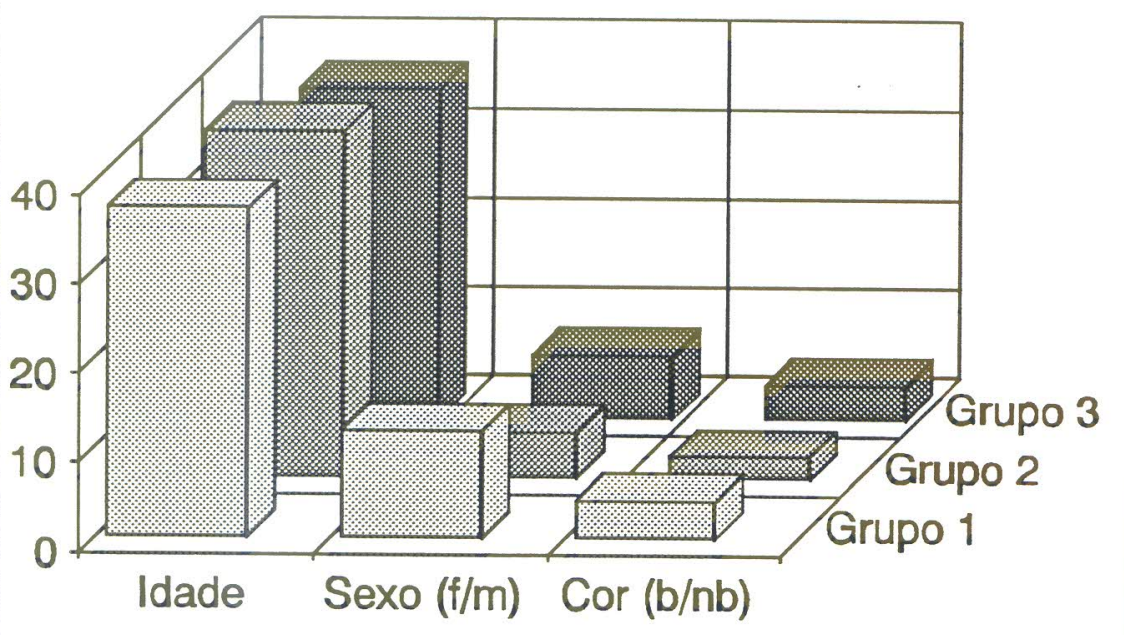

Figura 5.1 -

Características dos 3 grupo 


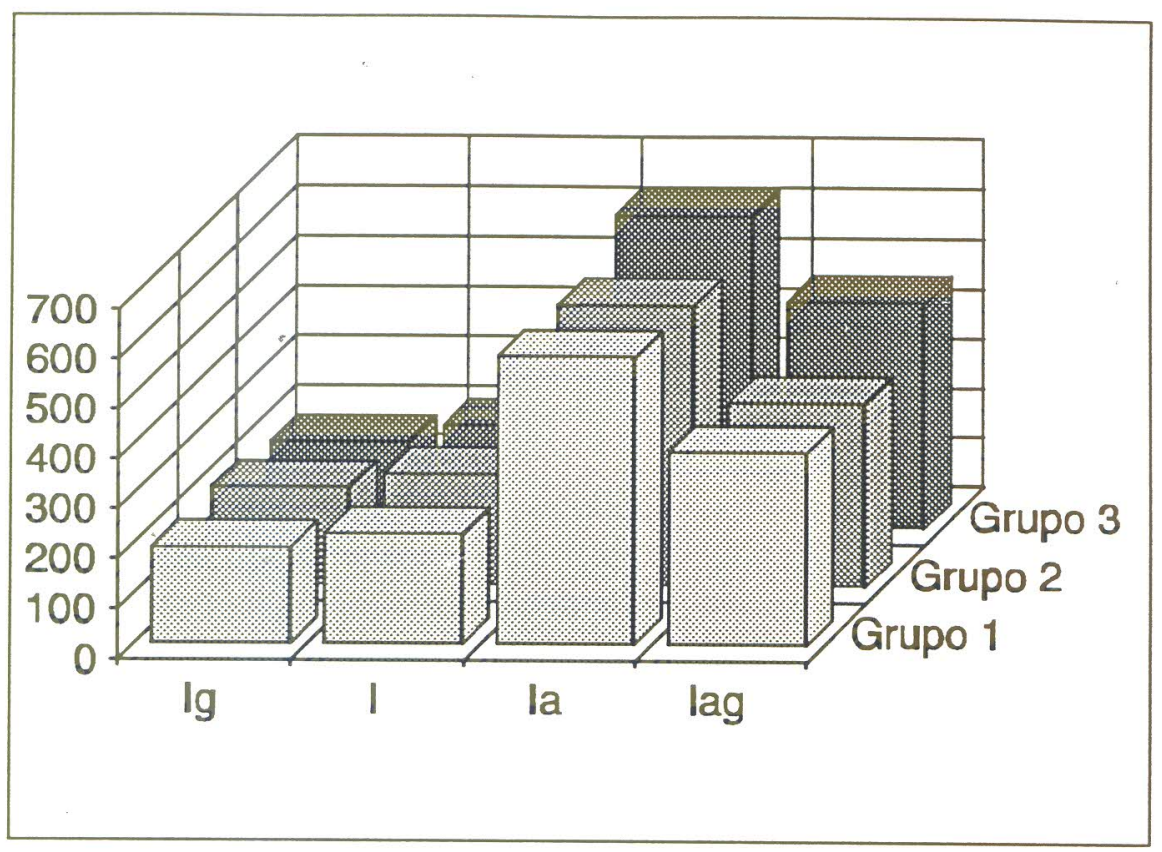

Figura 5.2 -

Avaliação

fonoaudiológica

pré-operatória

(fr. voc.)

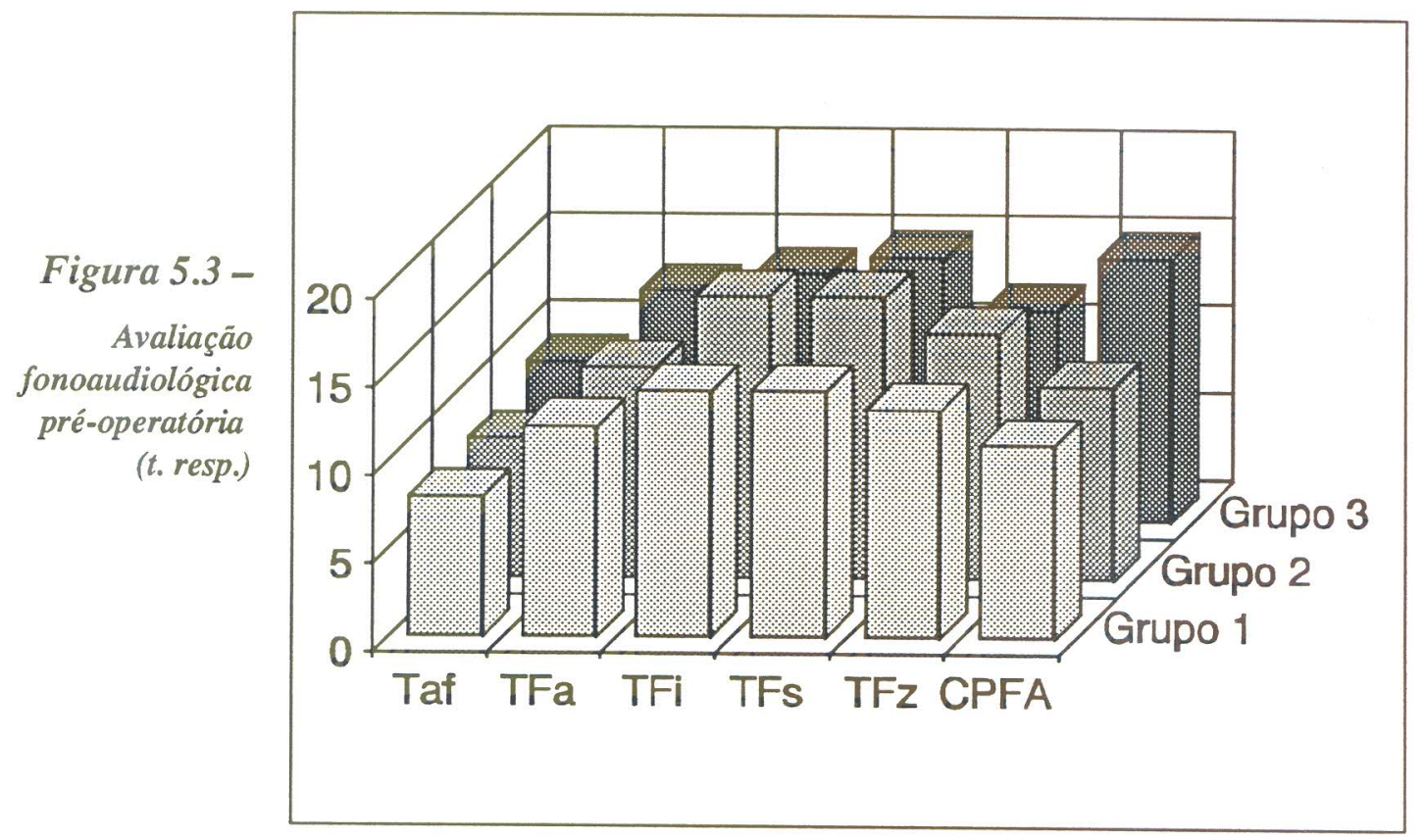

Houve um número maior de tireoidectomias totais nos Grupos 2 e 3. Como, porém, esta diferença não foi considerada significativa à avaliação estatística $(p=0,4125) e$, mais importante, o número de RELSs colocados em risco foi semelhante nos três grupos $(p=0,6245)$, a confiabilidade do estudo foi confirmada. Causou-nos espécie, todavia, a alta taxa de reoperações observada nesta casuística, pois dentre as 13 tireoidectomias totais, 9 (70\%) foram completadas num segundo tempo. Isto talvez deva ser atribuído a problemas intrínsecos de um Serviço de Anatomia Patológica de caráter universitário, que inclua, entre os seus objetivos, a árdua tarefa de introduzir aos seus Residentes as dificuldades técnicas de uma biópsia de congelação de ùma lesão tireoideana, principalmente se ela 
for do tipo "tumor folicular". Aliás, das 9 biópsias de congelação inconclusivas, 6 (67\%) resultaram carcinomas foliculares, 1 (11\%) revelou um carcinoma de Hürthle e $2(22 \%)$ eram carcinomas papilíferos. AUGUSTE \& ATTIE $^{8}$ comprovaram a segurança das reoperações sobre a glândula tireóide efetuadas dentro de um período inferior a 7 ou superior a 120 dias após o procedimento inicial. No presente estudo, todos os casos foram reoperados num período inferior a 10 dias, e as condições locais do leito operatório permitiram a realização de uma lobectomia total com a mesma técnica empregada na cirurgia anterior. Como já foi citado, uma doente (não incluída entre estes 9) foi reoperada após duas semanas, encontrando-se uma fibrose tal que dificultava a identificação segura das estruturas anatômicas, razão pela qual ela foi excluída do estudo. Dentre os 7 indivíduos que apresentaram uma lesão total do RELS no Grupo 2, apenas 2 (29\%) sofreram uma reoperação, enquanto que nenhum dos 3 doentes do Grupo 3 que exibiram esta lesão nervosa foram reoperados. Assim, não houve qualquer incremento aparente na taxa de complicações causado pela reoperação em si, apesar dos números, por serem pequenos, não permitirem análise estatística.

O tempo médio de duração do ato cirúrgico não variou significativamente entre os grupos, demonstrando que a adição da secção dos músculos pré-tiroideanos e da procura do RELS não foi responsável por um incremento importante no tempo operatório no Grupo 1 em relação aos demais. O tempo médio situou-se ao redor de três horas, bastante razoável para uma Disciplina que inclui, entre as suas finalidades principais, a formação de Residentes de 20. Ano de Cirurgia Geral que, geralmente, executam estes procedimentos.

A análise das dimensões e do peso das peças operatórias não mostrou diferenças significativas entre os três grupos, mantendo a sua comparabilidade. Por outro lado, fica evidente que o presente estudo não incluiu bócios de grandes dimensões, que, ao menos em teoria, poderiam carrear um maior risco, durante a sua retirada cirúrgica, de lesão do RELS. Talvez fosse interessante a realização de um trabalho, com a mesma metodologia deste, estudando a incidência de lesões do RELS em tireoidectomias feitas especificamente para bócios volumosos.

Houve diferenças nas proporções entre os diagnósticos histo-patológicos observados nos três grupos que, felizmente, não foram significativas sob o prisma estatístico. A freqüência anotada de tumores malignos (18\%) foi semelhante à aceita internacionalmente, que é de $20 \%$. Não houve casos de carcinomas medulares nesta série, visto que o tratamento cirúrgico preconizado para estas neoplasias na DCCP-HC FMUSP inclui sempre um esvaziamento ganglionar cervical de princípio, o que contribuiria para a sua exclusão do estudo. Analogamente, não se observou qualquer caso de carcinoma indiferenciado de tireóide, já que o seu tratamento compreende, habitualmente, cirurgias não padronizadas.

Cabe aqui um comentário a respeito da morbidade observada, principalmente no tocante às duas lesōes de nervo recorrente, uma transitória e a outra definitiva. Apesar de SHAHA \& $\mathrm{JAFFE}^{138}$ haverem constatado uma incidência de lesões definitivas do nervo recorrente em apenas $0,5 \%$ de 200 tireoidectomias consecutivas executadas por Médicos Residentes, é evidente que todo Serviço especializado em Cirurgia de Cabeça e Pescoço que se ocupe também da formação de Residentes de Cirurgia Geral tem que pagar um tributo, em morbidade, inerente à inexperiência daqueles que estão aprendendo. Assim, é compreensível que, numa Instituição dessa natureza, o índice de complicações seja ligeiramente mais alto do que noutra puramente assistencial ou do que na clínica particular. Paralelamente, não causou surpresa a constatação de um número mais elevado de lesões do RELS no Grupo 2 em relação ao 3. 
No Grupo 1 deste estudo, 28 RELS foram pesquisados em 26 doentes. Como vimos, as proporções entre os diferentes tipos de nervos, consoante a classificação proposta, foram ligeiramente diversas daquelas anotadas durante as dissecções anatômicas (Fig. 4.6). É possível que estas desigualdades devam ser atribuídas a características diferentes dos acessos cirúrgicos empregados para a identificação do RELS nas duas populações: enquanto que, entre os cadáveres, este acesso era obtido através da confecção de um amplo retalho cérvico-torácico, nos doentes ele era proporcionado apenas pela secção da musculatura pré-tireoideana. A clara identificação do nervo com o uso do neuro-estimulador nos casos clínicos não pode, obviamente, ser reproduzida nos cadáveres, nos quais o único auxílio é conferido pelos referenciais anatômicos. Por esta razão, cremos que a proporção verificada nesta segunda parte do estudo deva ser a que mais se aproxime do real. Destarte, ao redor de $11 \%$ dos RELSs (do Tipo 2b) devem, na verdade, representar o contingente de alto risco de lesão.

É indispensável a secção da musculatura pré-tireoideana para a identificação do RELS? Acreditamos que não. Apesar de, no planejamento deste estudo, ela ter sido incluída em todos os casos pertencentes ao Grupo 1, isto se deveu à necessidade de se tentar uma identificação positiva em todos eles, mesmo nos nervos mais altos, movida pela própria índole prospectiva do trabalho. Como vimos, a maioria dos RELSs ou não foi identificada ou era do tipo 1, ou seja, encontravam-se naturalmente protegidos por uma situação mais alta. Mais importante, contudo, é o cirurgião, durante a ligadura dos ramos vasculares do polo superior tireoideano, visualizá-los adequadamente e, principalmente, estar atento à possibilidade da presença do nervo junto a esses ramos, que devem sempre ser ligados individualmente e tanto mais próximo do parênquima glandular quanto for possível. Qualquer estrutura que se assemelhe ao RELS, nesta região, deve ser positivamente identificada neste tempo operatório. Autores há ${ }^{38,82,101}$ que julgam suficiente o reconhecimento do nervo baseado apenas em suas características anatômicas. Concordamos, todavia, com FRIEDMAN e col. ${ }^{55,56}$, que consideram imperiosa uma identificação morfo-funcional do RELS, através da comprovação da sua atividade pela contração do MCT, obtida à sua estimulação elétrica. Assim, qualquer estrutura suspeita só deve ser seccionada se a sua estimulação elétrica não resultar em qualquer atividade motora no MCT, que deverá, evidentemente, se encontrar sob visão direta no próprio campo operatório. Este, aliás, foi o procedimento adotado naqueles dois casos do Grupo 1 nos quais o nervo, após exaustiva procura, não foi encontrado. Se, por outro lado, o tamanho do bócio não permitir a adequada visualização do polo superior apenas com o afastamento lateral dos músculos pré-tireoideanos, justificar-se-á então a sua secção, seguida da tentativa de identificação positiva do RELS. Vale aqui citar que não se constatou qualquer efeito deletério para a fonação após a secção destes músculos nos indivíduos do Grupo 1. Isto viria a corroborar os achados de FAABORG-ANDERSEN \& SONNINEN ${ }^{43}$, que não foram capazes de notar uma atividade importante deste músculos durante a produção de sons agudos, ou seja, durante a atuação principal do MCT.

O tempo gasto para a identificação do RELS girou em torno de 13 minutos. Entretanto, à medida em que o Autor foi se habituando à visualização do nervo, ou seja, entre os últimos casos do estudo, este tempo não ultrapassou a marca de 3 minutos. Quanto tempo se deve dispender na procura do RELS? É uma questão de difícil resposta. Neste estudo, foram gastos, nos dois casos em que o nervo não foi achado, 50 e 28 minutos, tempos estes frutos da própria inexperiência do Autor com esta procura. É provável que o nervo que não foi localizado ao cabo de 10 ou 15 minutos de pesquisa diligente e minuciosa ocupe uma posição tal que dificilmente será visualizado no campo de uma tireoidectomia. 
A avaliação fonoaudiológica pós-operatória precoce efetuada nos indivíduos do Grupo 1 demonstrou, quando comparada com a pré-operatória, um resultado até certo ponto surpreendente: não só a voz não piorou como, sob alguns aspectos, até melhorou após a cirurgia. Na única referência encontrada na literatura internacional que analisava, sob o ponto de vista fonoaudiológico, a influência das tireoidectomias sobre a performance vocal, WATT-BOOLSEN e col. ${ }^{158}$ notaram que $75 \%$ dos 20 doentes por eles estudados exibiram uma melhora desta performance após a operação. Qual seria a explicação mais plausível para este desempenho vocal superior? Talvez a resposta se encontre numa melhoria da capacidade vibratória do complexo laringo-traqueal, ao se retirar a glândula tireóide patológica adjacente, sem interferir com a sua inervação. Além disso, talvez o alívio da compressão traqueal, mesmo que discreta, que era ocasionada pela glândula doente, contribua para uma melhoria nas condições aerodinâmicas do fluxo respiratório. Esta pode ser a razão pela qual alguns parâmetros eminentemente respiratórios (Taf, TFa, TFs, TFz e CPFA) tenham mostrado um desempenho significativamente superior entre os pacientes do Grupo 1.

Nos doentes do Grupo 2, foi constatada uma piora estatisticamente significativa, principalmente no tocante ao Ig e ao Ia, refletindo uma incidência importante de lesões completas do RELS. Além disso, houve uma redução significativa na extensão vocal. É interessante assinalar que, se o comprometimento na capacidade de emissão dos tons mais agudos é compreensível neste grupo, pelas próprias características fisiológicas do MCT, o rebaixamento do Ig espelharia também um verdadeiro deslocamento da extensão vocal, já mais limitada, para baixo na escala tonal. Isto demonstrou claramente uma influência deletéria da lesão completa do nervo no desempenho vocal como um todo. Vale notar também que, se aqui houve uma tendência à melhoria da performance vocal consequente à ablação da tireóide adjacente (analogamente ao que foi mencionado no parágrafo anterior), ela foi mascarada pela piora do desempenho vocal médio deste grupo, ocasionada pelo significativo contingente de indivíduos que sofreram uma lesão completa do RELS.

Causou espécie a acentuada queda no Ia observada no Grupo 3, associada à severa redução da extensão vocal, principalmente se levarmos em conta que o número de lesões totais do RELS foi bastante inferior neste grupo, em relação ao Grupo 2. Esta deterioração na capacidade de emitir sons agudos, apesar de uma atividade elétrica presente no $\mathrm{MCT}$, foi provavelmente fruto de uma lesão incompleta do RELS em uma proporção importante de indivíduos deste grupo. Como já foi discutido acima, uma das limitações da eletromiografia do MCT foi a dificuldade para a detecção de alterações quantitativas da atividade elétrica do músculo, já que pequenas modificações na posição do eletrodo na intimidade das fibras musculares resultavam em traçados eletromiográficos muito diferentes. Por esta razão, somente o "silêncio elétrico" foi levado em consideração na análise dos resultados. Assim, é possível que, principalmente neste grupo, operado pelo Autor sem a preocupação de identificar o RELS, a proporção de lesões parciais do nervo (não identificadas à eletromiografia), em relação às lesões totais, tenha sido maior do que no Grupo 2 e tenha contribuído de forma decisiva para esta piora na produção dos sons mais agudos. Ficaria, assim comprovada, do ponto de vista fonoaudiológico, que a identificação e preservação do RELS levada a cabo no Grupo 1, seria uma forma eficaz de evitar a sua lesão, mesmo que parcial, visto que ela foi mais encontradiça entre os doentes do Grupo 3, operados pelo mesmo cirurgião sem, contudo, pesquisar o nervo.

A eletromiografia do MCT mostrou ser, neste estudo, o método de maior utilidade para a comprovação indiscutível da lesão completa do RELS, confirmando a opinião de vários auto$\operatorname{res}^{42,30,89,61,15,17}$. Aliás, como foi ressaltado por $\operatorname{DEDO}^{30}$ e por HAGLUND e $\operatorname{col}^{61}$, a simples laringoscopia indireta de rotina não foi capaz de surpreender alterações detectáveis nas pregas vocais. 
É provável que a videoestroboscopia de laringe pudesse detectar as sutis mudanças no formato, na superfície e no aspecto da corda vocal afetada. Este método, porém, não foi aqui empregado.

A execução da eletromiografia do MCT é muito mais fácil do que para os demais músculos intrínsecos da laringe, como atestam vários especialistas $42,70,67,30$. No presente estudo, utilizamos o método sugerido por HIRANO ${ }^{67}$ e modificado por HAGLUND ${ }^{62}$, atingindo ambos os músculos pela mesma punção cutânea feita na linha média. O Autor encontrou uma certa dificuldade para vencer a fibrose resultante da dissecção do retalho cirúrgico cranial, mesmo tomando o cuidado de não executar nenhum exame antes do 30o. dia do período pós-operatório. Em nenhum caso, entretanto, os pontos de referência anatômicos para a localização do MCT (cartilagens cricóide e tireóide) deixaram de ser identificados. Apesar de ser um método invasivo, numa região préviamente operada, não foi anotada nenhuma complicação a ele consequente, corroborando a experiência de HAGLUND $^{62}$.

Alguns dados do estudo clínico foram comparados estatisticamente com a incidência de lesão total do RELS, constatada à eletromiografia precoce. Observou-se que algumas variáveis que poderiam, ao menos teoricamente, aumentar o risco de lesão nervosa, como desvio de traquéia, tireoidectomia parcial $\mathrm{X}$ total e tumores benignos $\mathrm{X}$ malignos, não diferiram entre si. Entretanto, o grupo de estudo ao qual os doentes pertenciam $(1,2$ ou 3$)$ e, surpreendentemente, a cor dos pacientes, interferiram de forma significativa na incidência de lesões totais do RELS. Se, por um lado, a constatação de uma diferença no risco de lesão entre os três grupos constituiu o próprio objetivo deste estudo, por outro, é difícil se explicar porque os doentes não-brancos apresentaram um risco significativamente maior de lesão do nervo neste estudo. Uma hipótese que poderia ser levantada é que estes pacientes poderiam exibir, como uma característica racial, uma incidência maior de configurações anatômicas do RELS de alto risco. A resposta a essa questão, contudo, só poderia advir de um estudo anatômico prospectivo em larga escala.

A correlação entre os achados verificados às avaliações fonoaudiológica e eletromiográfica precoces demonstrou, como já era previsto, uma fortíssima associação entre a lesão completa do RELS e a queda nas freqüências vocais mais agudas, indo de encontro a todas aquelas opiniões existentes na literatura internacional que defendiam u'a maior atividade do MCT na produção dos sons mais agudos $84,5,6,68,102,141$. Fica evidente, assim, a importância funcional deste músculo que, ao se contrair, aumenta a tensão da prega vocal correspondente (Fig. 5.4). Provavelmente, esse rebaixamento nas freqüências mais agudas foi o grande responsável pela marcada redução na extensão vocal dos doentes com lesão completa do RELS. Por outro lado, também foi documentada uma queda da frequiência fundamental quando houve esta lesão, confirmando os achados de HIRANO ${ }^{68}$, o qual afirmou que a ação do MCT influiria não só na produção das notas mais altas como também, em menor escala, na freqüência fundamental. A diminuição no TFz constatada entre os indivíduos com lesões totais poderia espelhar a fadiga vocal que vários deles referiram, secundária a uma diminuição no tônus da prega vocal, que também seria responsável por uma redução na sua capacidade vibratória (fundamental para a emissão do fonema " $z$ ").

Não se demonstrou uma correlação estatisticamente significativa entre os dados obtidos à avaliação fonoaudiológica pós-operatória e a eletromiografia tardias, denotando, talvez, uma certa tendência à recuperação funcional em alguns casos, por mecanismos ainda obscuros. Deve-se ressaltar, não obstante, que os números muito reduzidos dificultaram uma comparação mais fundamentada. 


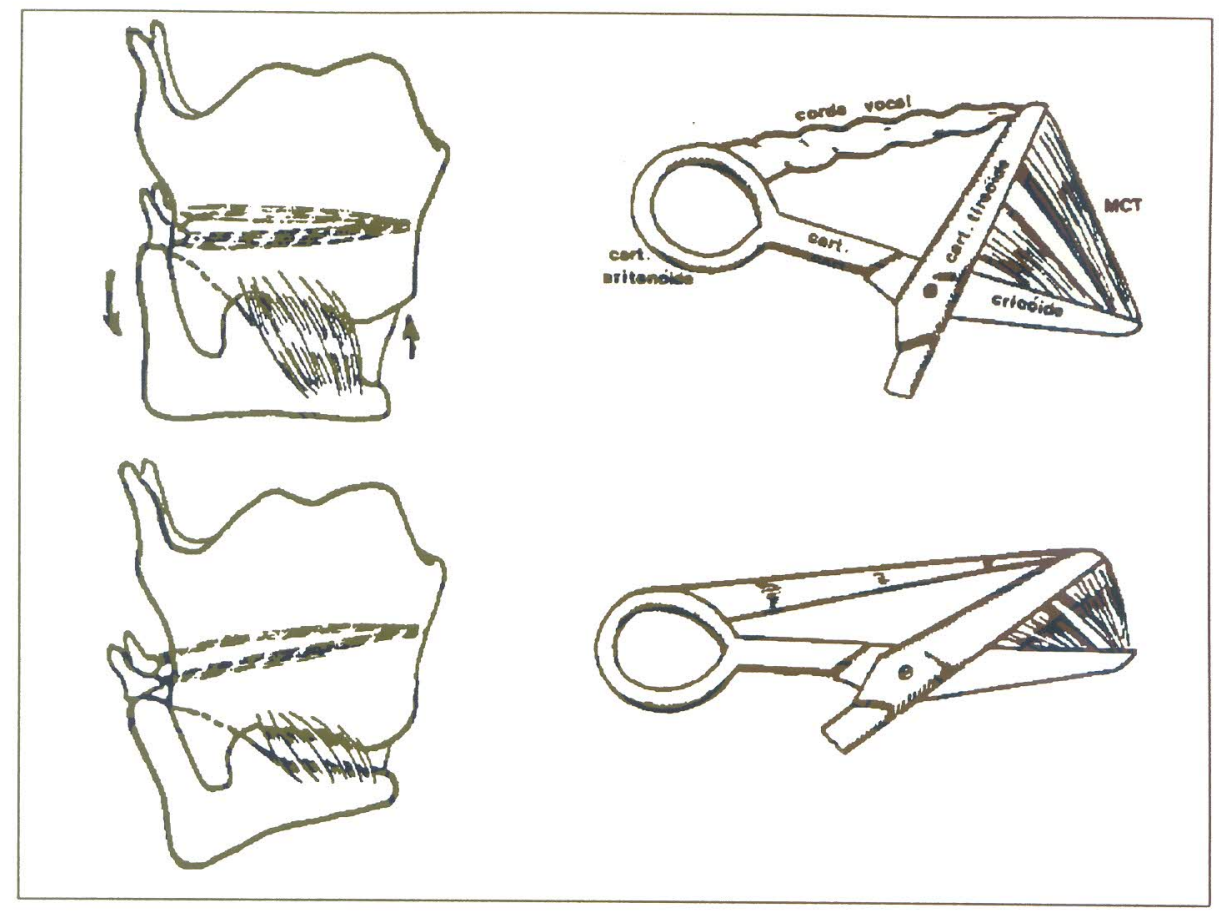

Figura 5.4-

Representação esquemática da ação do MCT como tensor da prega vocal [modificada de KIRCHNER (87)]

A inexistência de lesões, parciais ou completas, do RELS entre os casos do Grupo 1 demonstrou que a prospeç̧ão do nervo objetiva e criteriosa foi a única forma eficaz de prevenir o seu comprometimento inadvertido durante uma tireoidectomia. É verdade que a diferença estatisticamentẹ significativa observada ao se compararem os Grupos 1 e 2, sob o prisma eletromiográfico, poderia ser em parte atribuída ao fato de os pacientes do segundo grupo terem sido operados por cirurgiões menos experientes, ainda em formação. Mesmo entre os casos operados pelo próprio Autor no Grupo 3 , no entanto, constataram-se 3 lesões iatrogênicas do RELS que, se não atingiram uma evidente discrepância estatística no restrito universo analisado, demonstraram uma nítida diferença no que tange à profilaxia destas lesões nervosas. Mais importante, porém, foi a demonstração cabal de que, quando cotejados com os RELSs que não foram colocados em risco, correspondentes aos polos superiores tireoideanos não operados, os nervos do Grupo 1 foram os únicos a não exibirem um percentual de lesão estatísticamente maior, o que não se verificou nos outros dois grupos.

Outro motivo que estimula a tentativa de identificação intra-operatória do RELS é a sua simplicidade. Enquanto que, para a comprovação intra-operatória da localização do nervo recorrente em casos selecionados, os métodos disponiveis são difíceis e trabalhosos ${ }^{90,91,161,169,103,128}$, o MCT usualmente se acha exposto no próprio campo cirúrgico, fazendo com que a sua contração, em resposta à estimulação elétrica do RELS, seja facilmente visualizada.

Fica difícil a comparação dos resultados obtidos neste estudo com os outros disponíveis na literatura que relatam a freqüência de lesões do RELS, seja pela precariedade da metodologia 
empregada, seja pela falta de randomização nos poucos estudos prospectivos. Assim, FARENZENA e $\mathrm{col}^{46}$, num estudo retrospectivo, acharam $23,1 \%$ de casos portadores de paralisia do RELS, baseando-se apenas na laringoscopia indireta. Por outro lado, LEKACOS e col. ${ }^{99}$ no único estudo prospectivo e randomizado que foi encontrado na literatura internacional, compararam indivíduos nos quais foi feita uma ligadura alta da artéria tireoídea superior (entre os quais detectaram 5,5\% de lesões do RELS, usando apenas a laringoscopia indireta e uma avaliação não quantitativa da voz) com outros nos quais os ramos vasculares foram ligados individualmente (não observando lesões nervosą). Ora, neste estudo, não só foi criticável a proposta de ligadura alta do pedículo vascular superior tireoideano como também deixou a desejar a metodologia empregada para se aferir a real freqüência de lesão. SHAHA \& JAFFE ${ }^{138}$ acharam, retrospectivamente, 0,5\% de lesão do RELS em 200 doentes operados por Médicos Residentes; a única forma de verificação desta lesão, no entanto, foi a laringoscopia indireta. JANSSON e col. ${ }^{77}$, num estudo prospectivo, mas não randomizado, encontraram a marca de $58 \%$ de lesões iatrogênicas do nervo em 20 doentes operados por Cirurgiões Gerais, lançando mão de uma avaliação fonoaudiológica quantitativa e de uma eletromiografia do MCT. Ficam, pois, patentes dois aspectos: a) a grande heterogeneidade das metodologias dificulta sobremaneira qualquer comparação; b) de forma geral, quanto mais sofisticada a tecnologia e diligente a procura da lesão do RELS, com maior frequêencia ela será encontrada. Em nossa casuística, observamos $28 \%$ de lesões completas do RELS entre os doentes operados pelos Médicos Residentes de Cirurgia Geral da DCCP do HCFMUSP e $12 \%$ entre os casos operados pelo Autor, sem a preocupação de se identificar o nervo, números estes que, pela natureza prospectiva e randomizada do estudo e pela acuidade dos métodos empregados, devem refletir a real incidência desta lesão nervosa após tireoidectomias, em nossa Disciplina.

A identificação do RELS é, porventura, uma garantia de proteção contra a sua lesão? Não necessariamente, de acordo com a escassa literatura disponível. KARK e col. ${ }^{82}$ procuraram 56 nervos, identificando, guiados pelas suas características anatômicas, somente 47. Usando apenas uma avaliação quantitativa da freqüência vocal, notaram lesão em $25 \%$ dos casos. Já LENNQUIST e col. ${ }^{101}$, também baseando-se tão somente nas características anatômicas, foram capazes de identificar 36 de 50 nervos pesquisados. Utilizando a laringoscopia indireta e uma avaliação fonoaudiológica quantitativa, foram capazes de detectar só um caso (2\%) de lesão do RELS, numa situação de uma hemorragia intra-operatória de difícil controle na região do polo superior correspondente, em um indivíduo portador de bócio difuso tóxico. Infelizmente, os defensores do emprego do neuro-estimulador para a identificação intra-operatória do nervo ${ }^{85,55,56}$ não publicaram, até o momento, qualquer estudo prospectivo e randomizado sobre o assunto. Como já foi mencionado acima, a ausência de lesões iatrogênicas do RELS entre os casos do presente estudo nos quais o nervo foi objetivamente pesquisado com o auxílio do neuro-estimulador leva-nos a inferir que esta talvez seja a forma de identificação mais eficaz para se prevenir a sua lesão durante a abordagem cirúrgica do polo superior da glândula tireóide.

A avaliação fonoaudiológica tardia feita nos doentes do Grupo 2 que haviam sofrido uma lesão completa do RELS revelou, coletivamente, uma certa recuperação da performance vocal, seguramente fornecida pelo contingente de casos onde a lesão não foi definitiva. Entretanto, nota-se que a análise destes resultados mais tardios sob a perspectiva de um grupo, como um todo, revelou a persistência da deterioração da função vocal. Já no Grupo 3, o reduzido número de pacientes submetidos à avaliação fonoaudiológica tardia dificultou a aplicação do método estatístico, apesar de se constatar, em ambos os casos analisados, uma recuperação da capacidade fonatória a longo prazo. 
As lesões completas observadas à avaliação eletromiográfica precoce em 7 doentes do Grupo 2 persistiram à avaliação tardia em 4 (57\%). É provável que, nestas situações, haja ocorrido secção ou esmagamento do RELS, que não foi capaz de se regenerar, se levarmos em conta os achados de JUDD e col. ${ }^{80}$. Por que esta lesões foram definitivas se SIRIBODHI e col. ${ }^{140}$, ao analisarem 3 cães que tiveram os seus nervos intencionalmente seccionados junto aos MCTs, observaram uma reinervação funcionalmente efetiva em todos, num período inferior a 6 meses? A explicação deve se relacionar com o local em que o nervo foi seccionado. Enquanto que, nos casos operados, a lesão ocorreu ao nível do polo superior tireoideano e, por conseguinte, longe do MCT, nos animais de experimentação a secção do nervo foi executada junto ao músculo. Tratando-se de um único músculo com uma inervação motora exclusiva, a regeneração das fibras nervosas, mesmo que feita a esmo, teria logrado atingir o seu órgão efetor.

Os dois pacientes do Grupo 3 que foram avaliados pela eletromiografia do MCT tardiamente mostraram uma recuperação da sua atividade elétrica, traduzida também pela normalização da sua capacidade fonatória. Considerando-se uma vez mais o modelo preconizado por JUDD e $\operatorname{col}^{80}$, é provável que aqui, como nos outros 3 casos do Grupo 2 cujo déficit foi temporário, a lesão do RELS tenha sido ocasionada pelo seu estiramento ou pinçamento, sem haver uma solução de continuidade.

O fato de uma parte das lesões completas constatadas no Grupo 2 e de todas aquelas que foram analisadas do Grupo 3 terem retornado à normalidade não diminuem a real importância da pesquisa do RELS efetuada no Grupo 1. Em primeiro lugar, ficou evidenciado o risco potencial de lesão mesmo entre os casos operados pelo Autor. Em segundo, não se deve olvidar que mesmo a avaliação precoce só foi realizada ao redor de 1 mes após a operação. Ora, quanto tempo alguém que efetivamente dependa de um desempenho adequado da sua voz (uma cantora lírica, por exemplo) pode ficar afastado de suas atividades profissionais? Mesmo entre os casos do presente estudo, é difícil se precisar quando a voz se normalizou, pois para isto haveria a necessidade de se efetuarem avaliações fonoaudiológicas e eletromiográficas semanais ou mensais, o que seria obviamente impraticável.

Existe uma gama variada de possíveis causas de lesões do RELS, que vão desde um mecanismo psicogênico ${ }^{63}$ até doenças neurológicas e infecciosas ${ }^{120,6,44,147}$, passando por outras etiologias, algumas realmente lastimáveis ${ }^{66}$. Destacam-se, porém, os danos iatrogênicos ao nervo, após endaterectomias carotídeas $41,31,2$ ou, mais comumente, no decorrer de uma tireoidectomia.

Sem dúvida, a lesão iatrogênica definitiva do RELS tem consequências desastrosas para a carreira dos profissionais da voz, como muito bem demonstraram KARK e col. ${ }^{82}$ ao relatar o infeliz destino da soprano Amelita Galli-Curci. No presente estudo, a única cantora lírica foi a doente No. 2, pertencente ao Grupo 2, que, infelizmente, apresentou uma lesão completa definitiva do RELS, sendo obrigada a abandonar permanentemente a sua atividade no coral em que cantava. Paradoxalmente, a lesão definitiva do nervo recorrente, apesar da plêiade de consequências que acarreta, é, muitas vezes, passível de correção, ou naturalmente, por uma compensação oferecida pela prega vocal contralateral, ou pela intervenção médica lançando mão dos mais variados meios $72,152,75,146,127,39,149,130,18,139,135,127,117,151,111,118,28,7,107,108,153,9,76,37,106,93,119,122,92,21,137,86$. Por outro la-

do, os efeitos deletérios da lesão definitiva do RELS são perenes, não se encontrando na literatura pesquisada qualquer publicação que apresentasse sequer um esboço de reabilitação para esta paralisia. Assim, todos os esforços devem ser envidados no sentido de se prevenir a ocorrência desta complicação, pois uma vez já instalada, não há terapêutica disponível na atualidade. 


\section{CONCLUSÕES E INFERÊNCIAS}

\subsection{CONCLUSÕES}

A análise dos resultados obtidos permite concluir que:

6.1.1. A incidência de lesões completas do RELS entre os doentes do Grupo 3 que, durante a cirurgia, tiveram os polos superiores dissecados pelo Autor, sem procurar o nervo, foi de $12 \%$; estas lesões não foram definitivas nos dois $(67 \%)$ pacientes que se submeteram à avaliação tardia.

6.1.2. Ocorreu uma piora significativa na capacidade de emissão dos sons agudos e uma redução marcante na extensão vocal entre os pacientes do Grupo 3, consequência provável de uma incidência significativa de lesôes parciais do RELS que não foram detectadas pela eletromiografia do MCT.

6.1.3. Nenhum caso que foi submetido à prospecção do RELS pelo Autor desenvolveu lesão, parcial ou completa, deste nervo.

6.1.4. Ao se compararem os nervos colocados em risco nos três grupos com aqueles que não foram dissecados (Grupo 4), a incidência de lesão completa foi estatisticamente maior nos grupos nos quais o nervo não foi identificado (Grupos 2 e 3), ao passo que, no grupo em que ele foi pesquisado (Grupo 1), não foi anotada qualquer diferença.

6.1.5. A profilaxia eficaz contra a ocorrência de uma lesão iatrogênica do RELS só foi obtida, no presente estudo, mediante a sua pesquisa sistemática e minuciosa com neuro-estimulador, durante a dissecção do polo superior da glândula tireóide. 


\subsection{INFERÊNCIAS}

Além destas conclusões, algumas inferências podem ser feitas:

6.2.1. As lesões completas do MCT, comprovadas pela eletromiografia precoce, ocasionaram, na avaliação fonaudiológica pós-operatória precoce, um comprometimento na emissão dos sons agudos, uma queda na freqüência fundamental, uma redução na extensão vocal e uma piora na produção do fonema " $z$ ". A correlação entre as avaliações tardias não se revestiu de significado estatístico.

6.2.2. A incidência real de lesões completas do RELS em indivíduos submetidos à tireoidectomia por Médicos-Residentes de 20. Ano na DCCP-HC FMUSP foi de $28 \%$, das quais $57 \%$ foram definitivas.

6.2.3. Houve uma melhora objetiva na performance vocal entre os indivíduos nos quais o nervo foi pesquisado, traduzida por um desempenho estatisticamente superior dos parâmetros respiratórios da fonação no Grupo 1, coletivamente.

6.2.4. Observou-se uma incidência de lesões completas do RELS significativamente maior nos doentes não-brancos, quando comparados com os brancos. 


\section{REFERÊNCIAS BIBLIOGRÁFICAS}

1. ABELSON, T.I. \& TUCKER, H.M. Laryngeal findings in superior laryngeal nerve paralysis Otolaryngol. Head Neck Surg., 89: 463-470, 1981.

2. ALDOORI, M.I. \& BAIRD, R.N. Local neurological complication during carotid endarterectomy - J. Cardiovasc. Surg., 29: 432-436, 1988.

3. ANDRADE, M.A. Lesões do recorrente: como evitá-las no decurso das tireoidectomias. Rio de Janeiro, Jornal do Commercio, 1946.

4. ANDRADE, Sobrinho, J. \& SAPIA, E.S. Complicações das intervenções sobre a tireóide Rev. Paul.Med., 48: 125-132, 1956.

5. ARNOLD, G.E. Physiology and pathology of the cricothyroid muscle. Laryngoscope, 71: 687753, 1961.

6. ARNOLD, G.E. Vocal rehabilitation of paralytic dysphonia: VII. Paralysis of the superior laryngeal nerve. Arch. Otolaryngol., 75: 79-100, 1962.

7. ATTALI, J.P.; GIOUX, M.; URTASSUN, A.; HENRY, C.; VITAL, C.; TRAISSAC, L. Vocal cord abduction rehabilitation by nervous selective anastomosis. Laryngoscope, 98: 398-401, 1988.

8. AUGUSTE, L.J. \& ATTIE, J.N. Completion thyroidectomy for initially misdiagnosed thyroid cancer. Otolaryngol. Clin. North Am., 23: 429-439, 1990.

9. BALDISSERA, F.; CANTARELLA, G.; MARINI, G.; OTTAVIANI, F.; TREDICI, G. Recovery of inspiratory abduction of the paralyzed vocal cords after bilateral reinnervation of the cricoarytenoid muscles by one single branch of the phrenic nerve. Laryngoscope, 99: 12861292, 1989. 
10. BARROS, Filho, N.M. Contribuição para a anatomia do ramo externo do nervo laríngeo superior: sua aplicação à técnica das tireoidectomias. São Paulo, 1948. /Tese - Livre Docência Faculdade de Medicina da Universidade de São Paulo/.

11. BECKFORD, N.S.; MAYO, R.; WILKINSON, A.; TIERNEY, M. Effects of short-term endotracheal intubation on vocal function. Laryngoscope, 100: 331-336, 1990.

12. BERENDES, J. Störungen von atmung und stimme nach strumektomie. Med. Mschr., 8: 1-4, 1954.

13. BERLIN, D.D. \& LAHEY, F.H. Dissections of the recurrent and superior laryngeal nerves: the relation of the recurrent to the inferior thyroid artery and the relation of the superior to $a b$ ductor paralysis. Surg. Gynecol.Obstetr., 49: 102-104, 1929.

14. BEVAN, K.; GRIFFITHS, M.V.; MORGAN, M.H. Superior laryngeal nerve injury: an overlooked entity in the surgery of the head and neck. Br.J. Surg., 75: 817, 1988.

15. BEVAN, K.; MORGAN, M.H.; GRIFFITHS, M.W. The role and techniques of laryngeal electromiography. Clin. Otolaryngol., 13: 299-305, 1988.

16. BEYER, T.E. Traumatic paralysis of the cricothyroid muscle. Laryngoscope, 51: 296-298, 1941.

17. BLAIR, R.L. Laryngeal electromiography. Arch. Otorhinolaryngol., 246: 396-396, 1989.

18. BOFENKAMP, B. Bilateral vocal cord paralysys. Minnesota Med., 18: 257-259, 1966.

19. BRANDÃO, L.G. \& FERRAZ, A.R. Bócios tóxicos. In: BRANDÃO, L.G. \& FERRAZ, A.R., ed. Cirurgia de cabeça e pescoço. São Paulo, Roca, 1989. V. 1, p. 590-601.

20. BRITTO e SILVA, Filho, G.; FERRAZ, A.R.; BRANDÃO, L.G.; CORDEIRO, A.C.; CORIOLANO, M.R.A.; TOLEDO, A.C. O tratamento da tireotoxicose pelas tireoidectomias sub-totais amplas: principais complicaçōes, conduta e aspectos profiláticos (Considerações estribadas numa casuística de 523 casos de bócios tóxicos operados). Rev. Bras. Cir. Cab. Pesc., 2: 1$25,1975$.

21. BRONIATOWSKI, M. Bionic larynx: electronic control of the reimplanted organ in the dog. Laryngoscope, 98: 1107-1115, 1988.

22. BURNETT, C.H.; CONNER, P.S.; DENNIS, F.S.; KEEN, W.W.; NANCREDE, C.B.; PARK, R.; PILCHER, L.S.; SENN, N.; SHEPHERD, FJ.; STIMSON, L.A.; THOMSON, W.; WARREN, J.C.; WIHTE, J.W. An american text-book of surgery. Philadelphia, Saunders, 1894. p. 636-639.

23. CAVO, Jr., J.W. True vocal cord paralysis following intubation. Laryngoscope, 95: 1352-1359, 1985. 
24. CAROSI, V. ; STANCANELLI, V.; BALANZONI, S. L'isolamento (di routine) dei nervi laringei nella chirurgia della tireoide. Minerva Med., 71: 1661-1664, 1980.

25. CLADER, D.N.; LUTER, P.W.; DANIELS, B.T. A photographic study of the superior and inferior laryngeal nerves and the superior and inferior thyroid arteries. Am. Surg., 23: 609-618, 1957.

26. CLOUSE, R.; FLYNN, M.B. Laryngeal nerve injury during thyroid surgery. J. Kentucky Med. Ass., 32: 545-548, 1985.

27. CORDEIRO, A.C. Complicações da cirurgia da tireóide. In: FERRAZ, A.R., ed. Atualização terapêutica em moléstias da tireóide. 5. ed. São Paulo, Faculdade de Medicina da Universidade de São Paulo, 1979. p. 135-140.

28. CRUMLEY, R.L.; IZDEBSKI, K.; MCMICKEN, B. Nerve transfer versus teflon injection for vocal cord paralysis: a comparison. Laryngoscope, 98: 1200-1204, 1988.

29. CRUMLEY, R.L. Repair of the recurrent laryngeal nerve. Otolaryngol. Clin. North Am., 23: 553-562, 1990.

30. DEDO, H.H. The paralyzed larynx : an electromiographic study in dogs and humans. Laryngoscope, 80: 1455-1517, 1970.

31. DEHN, T.C.B. \& TAYLOR, G.W. Cranial and cervical nerve damage associated with carotid endarterectomy. Br.J.Surg., 70: 365-368, 1983.

32. DESAI, P.B. The significance of the "other" laryngeal nerves in thyroid surgery. J. Indian Med.Assoc., 36: 325-326, 1961.

33. DOMEIJ, S.; CARLSÖO, B.; DAHLQVIST, A.; HELLSTRÖM, S.; KOURTOPOULOS, H. Motor and sensory fibers of the superior laryngeal nerve in the rat. Acta Otolaryngol. (Stockh.), 108: 469-477, 1989.

34. DROULIAS, C.; TZINAS, S.; HARLAFTIS, N.; AKIN, J.T.; GRAY, S.W.; SKANDALAKIS, J.E. The superior laryngeal nerve. Am. Surg., 42: 635-638, 1976.

35. DURHAM, C.F. \& HARRISON, T.S. The surgical anatomy of the superior laryngeal nerve. Surg. Gynecol. Obstetr., 118: 38-44, 1964.

36. EDIS, A.J. Prevention and management of complications associated with thyroid and parathyroid surgery. Surg. Clin. North Am., 59: 83-92, 1979.

37. EJNELL, H.; MANSSON, I.; BAKE, B.; HALLÉN, O.; STENBORG, R.; LINDSTRÖM, J. A simple operation for bilateral vocal cord paralysis. Laryngoscope, 94: 954-958, 1984.

38. ELNER, A.; FEX, S.; INGELSTED, S. Nerve injury in thyroid surgery. Acta Chir. Scand., 134: 103-105, 1968. 
39. ESCAJADILLO, J.R. Technique for external repositioning of the paralyzed vocal cord with silastic implant. Ann. Otol. Rhinol. Laryngol., 97: 234-238, 1988.

40. ESPINOZA, J.; HAMOIR, M.; DHEM, A. Preservation of the external branch of the superior laryngeal nerve in thyroid surgery. An anatomic study of 30 dissections. Ann. Otolaryngol. Chir. Cervicofac., 106: 127-134, 1989.

41. EVANS, W.E.; MENDELOWITZ, D.S.; LIAPIS, C.; WOLFE, V.; FLORENCE, C.L. Motor speech deficit following carotid endarterectomy. Ann. Surg., 196: 461-464, 1982.

42. FAABORG-ANDERSEN, $K$. Electromyographic investigation of intrinsic laryngeal muscles in humans: an investigation of subjects with normally movable vocal cords and patients with vocal cords paresis. Copenhagen, 1957. /Thesis for den Medicinske Doktorgrad/.

43. FAABORG-ANDERSEN, $K$ \& SONNINEN, A. The function of the extrinsiv laryngeal muscles at different pitch. Acta Otolaryngol., 51: 89-93, 1959.

44. FAABORG-ANDERSEN, K. \& JENSEN, A.M. Unilateral paralysis of the superior laryngeal nerve. Acta Otolaryngol., 57: 155-159, 1963.

45. FAABORG-ANDERSEN, K.; YAMAGIHARA, N.; von LEDEN, $H$. Vocal pitch and intensity regulation: a comparative study of electrical activity in the cricothyroid muscle and the airflow rate. Arch. Otolaryngol., 85: 122-128, 1967.

46. FARENZENA, P.R.; AMARAL, R.E.; COSTA, J.F.; LETTI, N. A voz nas lesões do nervo laríngico superior nos tireoidectomizados. Rev. Bras. Otorrinolaring., 45: 149-152, 1979.

47. FERRAZ, A.R. \& TOLEDO, A.C. Aspectos técnicos no tratamento do bócio nodular. Rev. Hosp. Clín. Fac. Med. S. Paulo, 34: 88-92, 1979.

48. FERRAZ, A.R. \& BRANDÃO, L.G. Bócio simples. In: BRANDÃO, L.G. \& FERRAZ, A.R., ed. Cirurgia de cabeça e pescoço. São Paulo, Roca, 1989. v. 1, p. 569-581.

49. FINOCHIETTO, R. Nervios recurrente e laringeo externo. Pren. Méd.Argent., 46: 1340-1344, 1959.

50. FISCHER, N.D. Preliminary report on an application of the motor function of the superior laryngeal nerve. Ann. Otol. Rhinol. Laryngol., 61: 352-353, 1952.

51. FORT, J.A. Anatomie descriptive et dissection. Paris, Octave Doin, 1892. t. III, p. 2-31.

52. FOWLER, C.H.\& HANSON, W.A. Surgical anatomy of the thyroid gland with special reference to the relations of the recurrent laryngeal nerve. Surg. Gynecol.Obstetr., 49:59-65, 1929.

53. FREEDMAN, L.M. The role of the cricothyroid muscle in tension of the vocal cords: an experimental study in dogs designed to release tension of the vocal cords in bilateral recurrent laryngeal nerve paralysis. Laryngoscope, 66: 574-581, 1956. 
54. FRIEDMAN, M.; TORIUMI, D.M.; GRYBAUSKAS, V.; KATZ, A. Nonrecurrent laryngeal nerves and their significance. Laryngoscope, 96: 87-90, 1986.

55. FRIEDMAN, M. \& TORIUMI, D.M. Functional identification of the external laryngeal nerve during thyroidectomy. Laryngoscope, 96: 1291-1292, 1986.

56. FRIEDMAN, M. \& PACELLA, B.L. Total versus subtotal thyroidectomy: arguments, approaches and recommendations. Otolaryngol. Clin. North Am., 23: 413-427, 1990.

57. GAVILÁN, J. \& GAVILÁN, C. Recurrent laryngeal nerve: identification during thyroid and parathyroid surgery. Arch Otolaryngol. Head Neck Surg., 112: 1286-1288, 1986.

58. GIMIGLIANO-ARGENTINO, A. Anatomia chirurgica del nervo laringeo superiore. Rif. Med., 54: 1337-1339, 1938.

59. GISSELSSON, L. Laryngeal paralysis following thyroidectomy. Acta Chir. Scand., 99: 154$162,1949$.

60. GREGG, R.L. Avoiding injury to the extralaryngeal nerves. Ann. Otol. Rhinol. Laryngol., 66: 656-678, 1957.

61. HAGLUND, S. ; KNUTSSON, E.; MARTENSON, A. Electromiography in motor disorders of the larynx. Acta Otolaryngol., 75: 366-367, 1973.

62. HAGLUND, S. The normal electromiogram in human cricothyroid muscle. Acta Otolaryngol., 75: 448-453, 1973.

63. HARTMAN, D.E.; DAILY, W.W.; MORIN, K.N. A case of superior laryngeal nerve paresis and psychogenic dysphonia. J. Speech Hearing Disorders, 54: 526-529, 1989.

64. HENRY, J.F.; AUDIFRET, J.; DENIZOT, A.; PALN, M. The nonrecurrent inferior laryngeal nerve: review of 33 cases, including two on the left side. Surgery, 104: 977-984, 1988.

65. HEYD, G. Voice and breathing disabilities following following thyroid surgery. N.Y. State J. Med., 44: 1905-1909, 1944.

66. HILLSTROM, R.P.; COHN, A.M.; MCCARROL, K.A. Vocal cord paralysis resulting from neck injections in the intravenous drug use population. Laryngoscope, 100: 503-506, 1990.

67. HIRANO, M. Recent advance in laryngeal electromiography in human. Kurume Med.J., 16: 119-126, 1969.

68. HIRANO, M. Vocal mechanisms in singing: laryngological and phoniatric aspects. J. Voice, 2: $51-69,1988$. 
69. HIROTO, I.; HIRANO, M.; TOYOZUMI, Y.; SHIN, T. Electromiographic investigation of the intrinsic laryngeal muscles related to speech sounds. Ann. Otol. Rhinol. Laryngol., 76: 867871, 1967.

70. HIROTO, I.; HIRANO, M.; TOMITA, H. Electromiographic investigation of human vocal cord paralysis. Ann. Otol. Rhinol. Laryngol., 77: 296-304, 1968.

71. HOCKAUF, H. \& SAILER, R. Zur problematik postoperativer rekurrensparesen. Laryngol. Rhinol. Otol. (Stuttg.), 59: 250-254, 1980.

72. HOLINGER, P.H. Post-thyroidectomy laryngeal paralysis (bilateral): medical and surgical aspects. South. Med.J., 37: 169-175, 1944.

73. HORIUCHI, M. \& SASAKI, C.T. Cricothyroid muscle in respiration. Ann. Otol. Rhinol. Laryngol., 87: 386-391, 1978.

74. HUNT, C.J. The superior laryngeal nerve as related to thyroid surgery. Am. Surg., 27: 548-552, 1961.

75. HYBELS, R.L. Selected new techniques of laryngeal surgery. Surg. Clin. North Am., 60: 637$647,1980$.

76. JACOBS, I.N.; WU, B.L.; SANDERS, I.; BILLER, H.F. Reinnervation of the canine posterior cricoarytenoid muscle with sympathetic preganglionic neurons. Ann. Otol. Rhinol. Laryngol., 99: 167-174, 1990.

77. JANSSON, S.; TISELL, L.E.; HAGNE, I.; SANNER, E.; STENBORG, R.; SVENSSON, P. Partial laryngeal nerve lesions before and after thyroid surgery. World.J. Surg., 12: 522-527, 1988.

78. JESCHEK, J. Sur l'innervation motrice di larynx. Rev. Laryngol. Otol. Rhinol., 77: 468-472, 1956.

79. JOHNSON, J. Effect of superior laryngeal nerves on tracheal mucus: an experimental study of the relationship. Ann. Surg., 101: 494-499, 1935.

80. JUDD, E.S.; NEW, G.B.; MANN, F.C. The effect of trauma upon the laryngeal nerves: and experimental study. Ann. Surg., 87: 257-262, 1918.

81. KAMBIC, V.; ZARGI, M.; RADSEL, Z. Topographic anatomy of the external branch of the superior laryngeal nerve: its importance in head and neck surgery. J. Laryngol. Otol., 98: 1121$1124,1984$.

82. KARK, A.E.; KISSIN, M.W.; AUERBACH, R.; MEIKLE, M. Voice changes after thyroidectomy: role of the external laryngeal nerve. Br.Med.J., 289: 1412-1415, 1984. 
83. KARLAN, M.S.; CATZ, B.; DUNKELMAN, D.; UYEDA, R.Y.; GLEISCHMAN, S. A safe technique for thyroidectomy with complete nerve dissection and parathyroid preservation. Head \& Neck Surg., 6: 1014-1019, 1984.

84. KATSUKI, Y. The function of the phonatory muscles. Jap. Jour. Physiol., 1: 19-36, 1950.

85. KATZ, A. Extralaryngeal division of the recurrent laryngeal nerve. Am. J. Surg., 152: 407-409, 1986.

86. KOJIMA, H.; OMORI, K.; SHOJI, K.; HONJO, I.; ISSHIKI, N.; NAKAMURA, T.; SHIMIZU, Y. Laryngeal pacing in unilateral vocal cord paralysis. Arch. Otolaryngol. Head Neck Surg., 116: 74-78, 1990.

87. KIRCHNER, J.A. Surgically-induced disorders of the vocal cords. Connecticut Med., 28: $24-$ 28, 1964.

88. KOCHER, E.T. Indikationen und resultate bei krofoperationen. In: KOCHER, E.T. Chirurgische operationslehre. Jena, Gustav Fischer, 1907. 5 ed. p. 649-685.

89. KOTBY, M.N. \& HAUGEN, L.K. Clinical application of electromiography in vocal fold mobility disorders. Arch. Otolaryngol., 70: 428-437, 1970.

90. KRATZ, R.C. The identification and protection of the laryngeal motor nerves during thyroid and laryngeal surgery: a new microsurgical technique. Laryngoscope, 83: 59-78, 1973.

91. KRATZ, R.C. Vocal cord paralysis and thyroid surgery. Ann. Otol. Rhinol. Laryngol., 87: 383$385,1978$.

92. KRAUS, W.M.; AVIV, J.E.; SANDERS, I.; BILLER, H.F. Laryngeal electrode plataform: an indwelling device for mobilizing the vocal cords. Ann. Otol. Rhinol. Laryngol., 96: 674-679, 1987.

93. KURILOFF, D.B. ; GOLDSHER, M.; BLAUGRUND, S.M.; KRESPI, Y.P. Controlled laryngoplasty for vocal cord medialization: a technique using tissue expansion. Laryngoscope, 100: 615-622, 1990.

94. LAHEY, F.H. \& HOOVER, W.B. Injuries to the recurrent laryngeal nerve in thyroid surgery. Ann. Surg., 108: 545-562, 1948.

95. LAM, R.L.\& OGURA, J.H. Afferent projection of the superior laryngeal nerve in the brainstem. Neurology, 4: 620-632, 1954.

96. LANG, J.; NACHBAUR, S.; FISCHER, K.; VOGEL,E. Über den nervus laryngéus superior und die arteria laryngea superior. Acta anat., 130: 309-318, 1987. 
97. LARSON, C.H.; KEMPSTER, G.B.; KISTLER, M.K. Changes in voice fundamental frequency following discharge of single motor units in cricothyroid and thyroarytenoid muscles. $J$. Speech Hearing Disorders, 30: 552-558, 1987.

98. LAWSON, L.J. The superior and recurrent laryngeal nerves. Quart. Bull. Northw. Univ. Med. Sch., 22: 356-359, 1948.

99. LEKACOS, N.L. ; MILIGOS, N.D.; TZARDIS, P.J.; MAJIATIS, S.; PATOULIS, J. The superior laryngeal nerve in thyroidectomy. Am. Surg., 53: 610-612, 1987.

100. LEMERE, F. Innervation of the larynx: IV. An analysis of Semon's law. Ann. Otol. Rhinol. Laryngol., 43: 525-540, 1934.

101. LENNQUIST, S.; CAHLIN, C.; SMEDS, S. The superior laryngeal nerve in thyroid surgery. Surgery, 102: 999-1008, 1987.

102. LINDESTAD, P.A.; FRITZELL, B.; PERSSON, A. Evaluation of laryngeal muscle function by quantitative analysis of the EMG interference pattern. Acta Otolaryngol. (Stockh.), 109: 467-472, 1990.

103. LIPTON, R.J.; MCCAFFREY, T.V.; LITCHY, WJ. Intraoperative electrophysiologic monitoring of laryngeal muscle during thyroid surgery. Laryngoscope, 98: 1292-1296, 1988.

104. LORÉ, J.M. Symposium on the larynx: I. Practical anatomical considerations of the larynx. Laryngoscope, 43: 693-713, 1933.

105. LORÉ, Jr., J.M.; KIM, D.J.; ELIAS, S. Preservation of the laryngeal nerves during total thyroid lobectomy. Ann. Otol. Rhinol. Laringol., 86: 777-788, 1977.

106. MAHIEU, H.F. \& SCHUTTE, H.K. New techniques for voice improvement. Arch. Otorhinolaryngol., 246: 397-402, 1989.

107. MANIGLIA, A.J.; DODDS, B.; SORENSEN, K.; KUMAR, N.; KATIRJI, M.B. Newer techniques of laryngeal reinervation. Ann. Otol. Rhinol. Laryngol., 98: 8-14, 1989.

108. MANIGLIA, A.J.; DODDS, B.; KATIRJI, M.B.; SORENSEN, K.; ROSENBAUM, M.L. Newer technique of laryngeal reinnervation: superior laryngeal nerve (motor branch) as a driver of the posterior cricoarytenoid muscle. Ann. Otol. Rhinol. Laryngol., 98: 907-909, 1989.

109. MANSBERGER, A.R. One hundred years of surgical management of hyperthyroidism. Ann. Surg., 207: 724-729, 1988.

110. MATHEW, O.P.; WOODSON, G.E.; SANT'AMBROGIO, F.B.; SANT'AMBROGIO, G. Respiratory activity of the cricothyroid muscle. Ann. Otol. Rhinol. Laryngol., 97: 680-687, 1988.

111. MAY, M.; LAVORATO, A.S.; BLEYAERT, A.L. Rehabilitation of the crippled larynx: application of the Tucker technique for muscle-nerve reinnervation. Laryngoscope, 90: 1-18, 1980. 
112. MENASCHE, P.; MAMOUDY, P.; BLONDEAU, P. Le nerf larynge externe, danger possible de la chirurgie thyreoidienne. Ann. Chir., 30: 121-129, 1976.

113. MOOSMAN, D.A. \& DeWEESE, M.S. The external laryngeal nerve as related to thyroidectomy.- Surg. Gynecol. Obstetr., 89: 1011-1016, 1968.

114. MORAN, R.E. \& CASTRO, A.F. The superior laryngeal nerve in thyroid surgery. Ann. Surg., 134: 1018-1021, 1951.

115. MORRIS, J.B. \& SCHIRMER, W.J. The "right stuff": five Nobel Prize-winiing surgeons. Surgery, 108: 71-80, 1990.

116. MULLIGAN, E.J. Prognosis of laryngeal paralysis. Arch. Otolaryngol., 35: 732-734, 1942.

117. NARCY, P.; CONTENCIN, P.; VIALA, P. Surgical treatment for laryngeal paralysis in infants and children. Ann. Otol. Rhinol. Laryngol., 99: 124-128, 1990.

118. NEAL, G.D.; STEARNS, M.; SUTTON, D.; TRACHY, R.; CUMMINGS, C.W. Muscle transposition in the rehabilitation of the paralyzed larynx. Ann. Otol. Rhinol. Lryngol., 92:478-481, 1983.

119. NETTERVILLE, J.L.; ALY, A.; OSSOF, R.H. Evaluation and treatment of complications of thyroid and parathyroid surgery. Otolaryngol. Clin. North Am., 23: 529-551, 1990.

120. NEW, G.B. \& CHILDREY, J.H. Paralysis of the vocal cords: a study of two hundred and seventeen medical cases. Arch. Otolaryngol., 16: 143-159, 1932.

121. NORDLAN, M. The larynx as related to surgery of the thyroid based on an anatomical study.Surg. Gynecol. Obstetr., 51: 449-459, 1930.

122. OTTO, R.A.; DAVIS, W.; BETTEN, J.R.; DOWNEN, P.; OTTO, P.M. Electrophisiologic pacing of vocal cord abductors in bilateral recurrent laryngeal nerve paralysis. Am. J. Surg., 150: 447-451, 1985.

123. PAINEAU, J.; HINGRAT, J.Y.; LEHUR, P.A.; VISSET, J. Voix, nerfs laryngés el chirurgie thyroidienne. J. Chir. (Paris), 120: 367-372, 1983.

124. PEMBERTON, J.J. \& BEAVER, M.G. Anomaly of right recurrent laryngeal nerve. Surg. Gynecol. Obstetr., 53: 594-595, 1932.

125. PERZIK, S.L. Total thyroidectomy: indications, complications and sequelae. Am.J. Surg., 106: 744-747, 1963.

126. PICHLER, H. \& GISEL, A. The clinical significance of the ramification of the recurrent laryngeal nerves: a critical anatomical study. Laryngoscope, 67: 105-117, 1957. 
127. PONTES, P.A.L. \& ARRAIS,A. Paralisias laringicas. In: BRANDÃO, L.G. \& FERRAZ, A.R., ed. Cirurgia de cabeça e pescoço. São Paulo, Roca, 1989. v. 2, p. 331-338.

128. PREMACHANDRA, D.J.; RADCLIFFE, G.J.; STEARNS, M.P. Intraoperative identification of the recurrent laryngeal nerve and demonstration of its function. Laryngoscope, 100:94-96, 1990.

129. REGULES, E. Nervio laringeo superior y motilidad laringea. An. Oto-Rino-Laring. Uruguay, 5: 139-170, 1935.

130. REMACLE, M.; MARBAIX, E.; DECLAYE, X.; van den EECHAUT, J. Initial long-term results of collagen injection for vocal and laryngeal rehabilitation. Arch. Otorhinolaringol., 246: 403-406, 1989.

131. REYNIER, J. \& LAURIAN, C. Les nerfs laryngés en chirurgie thyroidienne. Chirurgie, 99: 241 $246,1973$.

132. ROEDER, C.A. Operations on the superior pole of the thyroid. Arch. Surg., 41: 448-459, 1931.

133. ROSA, J.C. Contribuiçāo para o estudo anatômico das relações do nervo laríngico recorrente com a artéria tireoídea inferior. São Paulo, 1961. / Tese de Doutorado - Faculdade de Medicina da Universidade de São Paulo/.

134. ROSENBERG, S.I.; MALMGREN, L.T.; WOO, P. Age-related changes in the internal branch of the rat superior laryngeal nerve. Arch. Otolaryngol. Head Neck Surg., 115: 78-86, 1989.

135. SAMPAIO, M.A. Paralisia recorrencial da laringe. In: BRANDÃO, L.G. \& FERRAZ, A.R., ed. Cirurgia de cabeça e pescoço. São Paulo, Roca, 1989. v. 2, p. 338-343.

136. SANDERS, G.; UYEDA, R.Y.; KARLAN, M.S. Nonrecurrent inferior laryngeal nerves and their association with a recurrent branch. Am.J. Surg., 146: 501-503, 1983.

137. SANDERS, I.; WU, B.L.; KRAUS, W.M.; AVIV, J.E.; MOREL, B.; BILLER, H.F. Transmucosal stimulation of laryngeal muscles. Ann. Otol. Rhinol. Laryngol., 98: 339-345, 1989.

138. SHAHA, A. \& JAFFE, B.M. Complications of thyroid surgery performed by residents. Surgery, 104: 1109-1114, 1988.

139. SINGER, M.I.; HAMAKER, R.C.; MILLER, S.M. Restoration of the airway following bilateral recurrent laryngeal nerve paralysis. Laryngoscope, 95: 1204-1207, 1985.

140. SIRIBODHI, C.; SUNDMÄKER, W.; ATKINS, J.P.; BONNER, F.J. Electromiographic studies of laryngeal paralysis and regeneration of laryngeal motor nerves in dogs. Laryngoscope, 73: 148-164, 1963.

141. SLAVIT, D.H.; LIPTON, R.J.; MCCAFFREY, T.V. Glottographic analysis of phonation in the excised canine larynx. Ann. Otol. Rhinol. Laryngol., 99: 396-402, 1990. 
142. SOW, M.L.; KOYALTA, M.; BENCHERKROUN, A.; DIOP, A. Le nerf laryngé externe dans le chirurgie d'exérèse thyroidienne. Correlations anatomo- -chirurgicales à propos de 30 dissections. Dakar Med., 27: 177-186, 1982.

143. STEWART, G.R.; MOUNTAIN, J.C.; COLCOCK, B.P. Non-recurrent laryngeal nerve. Br.J. Surg., 59: 379-381, 1972.

144. SUZUKI, M. \& KIRCHNER, J.A. Afferent nerve fibers in the external branch of the superior laryngeal nerve in the cat. Ann. Otol. Rhinol. Laryngol., 77: 1059-1070, 1968.

145. THOMASSIN, J.M. Le nerf laryngé supérieur. J. Fr. Oto-Rhino-Laryngol., 31: 139-150, 1982.

146. THOMÉ, R.S. Conduta na paralisia da corda vocal: experiência pessoal. In: BRANDÃO, L.G. \& FERRAZ, A.F., ed. Cirurgia de cabeça e pescoço. São Paulo, Roca, 1989. v. 2, p. 327-330.

147. THOMPSON, J.W.; ROSENTHAL, P.; CAMILON, F.S., Jr. Vocal cord paralysis and superior laryngeal nerve dysfunction in Reye's Syndrome. Arch. Otolaryngol. Head Neck Surg., 116: 46-48, 1990.

148. TOVI, F.; NOYEK, A.M.; CHAPNIK, J.S.; FREEMAN, J.L. Safety of total thyroidectomy: review of 100 consecutive cases. Laryngoscope, 99: 1233-1237, 1989.

149. TRAPP, T.K.; BERKE, G.S.; HANSON, D.G.; BELL, T.S.; WARD, P.H. Effect of vocal fold augmentation on laryngeal vibration in simulated recurrent laryngeal nerve paralysis: a stufy of teflon and phonogel. Ann. Otol. Rhinol. Laryngol., 98: 220-227, 1989.

150. TSCHIASSNY, K. Studies concerning the action of the musculus cricothyreoideus. Laryngoscope, 54: 589-604, 1944.

151. TUCKER, H.M. Human laryngeal reinervation. Laryngoscope, 86: 769-779, 1976.

152. TUCKER, H.M. Vocal cord paralysis- 1979: etiology and management. Laryngoscope, 90: 585 590, 1980.

153. TUCKER, H.M. Long-term results of nerve-muscle pedicle reinnervation for laryngeal paralysis. Ann. Otol. Rhinol. Laryngol., 98: 674-676, 1989.

154. URBAN, K. Erfahrungen über stimmbandschädigungen bei 6000 kropfoperationen. Zentralbl. Chir., 25: 1456-1461, 1934.

155. VERNETTI, L. Studio anatomo-chirurgico sui rapporti della branca esterna del nervo laringeo superiore con il peduncolo vascolare superiore della tireoide. Minerva Chir., 2: 427-432, 1947.

156. VISSET, J.; LEBORGNE, J.; BARBIN, J.Y. Le nerf larynge externe. Bull.Assoc. Anat. (Nancy), 59: 1001-1012, 1975. 
157. WARD, P.H.; BERCI, G.; CALCATERRA, T.C. Superior laryngeal nerve paralysis: an often overlooked entity. Trans. Am. Acad. Ophtalmol. Otolaryngol., 84: 78-89, 1977.

158. WATT-BOOLSEN, S.; BLICHERT-TOFT, M.; BOBERG, A. Influence of thyroid surgery on voice function and laryngeal symptoms. Br. J. Surg., 66: 535-536, 1979.

159. WIJETILAKA, S.E. Non-recurrent laryngeal nerve. Br.J. Surg., 65: 179-181, 1978.

160. WILLIAMS, R.G.; LESSER, T.H.J.; FOSTER, M.; GRIFFITH, G. Altered laryngeal function following thyroidectomy. Clin. Otolaryngol., 14: 281-283, 1989.

161. WOLTERING, E.A.; DUMOND, D.; FERRARA, J.; FARRAR, W.B.; JAMES, A.G. A method for intraoperative identification of the recurrent laryngeal nerve. Am.J. Surg., 148: 438-440, 1984.

162. WOODSON, G.E.; MATHEW, O.; SANT'AMBROGIO, F.; SANT'AMBROGIO, G. Effects of cricothyroid muscle contraction on laryngeal resistance and glottic area. Ann. Otol. Rhinol. Laryngol., 98: 119-124, 1989.

163. WOODSON, G.E. Effects of recurrent laryngeal nerve transection and vagotomy on respiratory contraction of the cricothyroid muscle. Ann. Otol. Rhinol. Laryngol., 98: 373-378, 1989.

164. WOODSON, G.E. Respiratory activity of the cricothyroid muscle in conscious humans. Laryngoscope, 100: 49-53, 1990.

165. YANAGIHARA, N. \& von LEDEN, H. The cricothyroid muscle during phonation. Ann. Otol. Rhinol. Laryngol., 75: 987-1006, 1966.

166. ZAIDMAN, M. Complicaciones postoperatorias de la tireoidectomia. Pren. Méd. Argent., 42: 3030-3034, 1954.

167. ZAVALETA, D.E.; DIAZ, E.C.; LEMBRANDE, R.O.; PIMENTEL, M.A.A. Lesiones nerviosas durante la tireoidectomia. Pren. Méd.Argent., 55: 323-325, 1968.

168. ZEMLIM, W.R. Speech and Hearing Science: Anatomy and Physiology. New Jersey, PrenticeHall, 1968. p. 110-219.

169. ZINI, C. \& GANDOLFI, A. Facial-nerve and vocal-cord monitoring during otoneurosurgical operations. Arch. Otolaryngol Head Neck Surg., 113: 1291-1293, 1987.

170. ZUCKERMANN, M.S. \& KUHN, M. Tireoidectomias: estudo retrospectivo de 463 casos operados. Rev.Assoc. Med.R. G. Sul, 29: 19-23, 1985. 


\section{RESUMO}

Na primeira parte deste estudo, foram dissecados 30 polos superiores tireoideanos, de 15 cadáveres frescos, com o intuito de se identificar o ramo externo do nervo laríngeo superior (RELS) e analisar as suas relações anatômicas com o pedículo superior da glândula tireóide. Obedecendo a uma classificação eminentemente anátomo-cirúrgica, 1 nervo (3\%) não foi localizado, 18 (60\%) eram do Tipo 1 (cruzando os vasos tireoideanos superiores acima de $1 \mathrm{~cm}$ de um plano horixontal que passava pela borda do polo superior tireoideano), 5 (17\%) eram do Tipo 2a (nervo a menos de $1 \mathrm{~cm}$ acima do plano acima descrito) e 6 (20\%) eram do tipo $2 \mathrm{~b}$ (nervo abaixo do plano). Esta última configuração anatômica foi considerada de alto risco de lesão iatrogênica durante uma hipotética tireoidectomia.

A seguir, foi executado um estudo clínico, prospectivo e randomizado. Setenta e seis doentes, após uma avaliação fonoaudiológica completa pré-operatória, foram divididos em tres grupos. No Grupo 1, o polo superior foi dissecado pelo Autor com lupa, pesquisando-se o RELS, após a secção dos músculos pré-tireoideanos, por meio de um neuro-estimulador e observando-se a consequente contração do músculo crico-tireoídeo (MCT) no próprio campo operatório. No Grupo 2, o polo superior tireoideano foi dissecado por Médicos-Residentes de 20. Ano de Cirurgia Geral, estagiando na Disciplina de Cirurgia de Cabeça e Pescoço do Hospital das Clínicas da Faculdade de Medicina da Universidade de São Paulo (DCCP-HC FMUSP), sem qualquer tentativa para se individualizar o RELS. Os indivíduos do Grupo 3 foram operados obedecendo à mesma técnica descrita no grupo anterior, pelo Autor. No período pós-operatório, foi repetida a avaliação fonoaudiológica e realizada uma eletromiografia de ambos os MCT. Os doentes que tiveram uma lesão completa do RELS, comprovada pela ausência de atividade elétrica do MCT, sofreram novas avaliações fonoaudiológica e eletromiográfica tardias, 6 meses após a cirurgia.

Nenhum caso do Grupo 1 apresentou lesão completa do RELS. No Grupo 2, 28\% dos pacientes exibiram esta lesão, que foi definitiva em 57\%. No Grupo 3, constataram-se lesões totais 
em $12 \%$ dos doentes; nenhuma das lesões analisadas tardiamente neste grupo foi definitiva. Quando comparados com os nervos não dissecados, houve um aumento estatisticamente significativo de lesões completas nos Grupos 2 ( $p=0,0002776)$ e 3 ( $p=0,0346393)$, enquanto que não houve diferença nos doentes do Grupo 1.

A avaliação fonoaudiológica revelou uma melhora nos parâmetros dos casos do Grupo 1 , mormente aqueles relacionados com a respiração. Observou-se uma deterioração da performance vocal nos doentes do Grupo 2, que persistiu, em parte, na avaliação fonoaudiológica tardia. Já no Grupo 3 foi marcante uma piora estatisticamente significativa nas frequências mais altas e uma redução acentuada na extensão vocal, que foram atribuídas a lesões parciais do RELS, não detectadas pela avaliação eletromiográfica.

Concluiu-se que a única forma eficaz de se prevenir uma lesão iatrogênica do RELS durante uma tireoidectomia foi a sua pesquisa sistemática e objetiva na região do polo superior, com o auxílio de um neuro-estimulador. 


\section{SUMMARY}

In the first part of this study, the external branch of the superior laryngeal nerve (RELS) was dissected in the region of 30 superior thyroid poles, in 15 fresh cadavers, with special attention for its anatomical relationship with the superior thyroid vessels. Four different kinds of nerves were found: Not localized - 1 (3\%) nerve; Type 1 (crossing the superior thyroid vessels more than 1 $\mathrm{cm}$ above a horizontal plane located at the upper limit of the superior thyroid pole) - 18 (60\%); Type $2 \mathrm{a}$ (nerve situated less than $1 \mathrm{~cm}$ above the plane) - 5 (17\%); Type $2 \mathrm{~b}$ (nerve below the plane) -6 (20\%). This last relationship was considered to be "high risk", regarding an iatrogenic lesion during a hypothetical thyroidectomy.

Then, a prospective randomized clinical study was undertaken. Seventy-six patients, after being submitted to a complete phonoaudiological evaluation, were divided in three groups. In Group 1, the superior thyroid pole was dissected by the Author with a loupe, searching the RELS with a nerve stimulator, after dividing the strap muscles to gain better exposure. The identification of the nerve was considered to be positive when a contraction of the cricothyroid muscle (MCT) was obtained. In Group 2, the superior thyroid pole was operated on by 2nd Year General Surgery Residents, training during a 1-month period at the Department of Head and Neck Surgery of Hospital das Clínicas of the University of Såo Paulo Medical School (DCCP-HC FMUSP), without any attempt to identify the RELS. In Group 3, the patients were operated on by the Author, according to the same technique described for the Group 2. In the postoperative period, the complete phonoaudiological evaluation was repeated and an electromiography of both MCTs was performed. Those cases who showed a complete lesion of the RELS, which was evident by the absence of any electrical activity of the MCT, underwent again both phonoaudiological and electromiographic evaluations, 6 months after the surgery.

No patient in Group 1 showed any complete lesion of the RELS. In Group 2, $28 \%$ of the cases suffered this lesion, which was definitive in $57 \%$. In Group 3,12\% of the patients had a complete paralysis of the nerve; none of the two lesions analyzed after 6 months $(67 \%)$ proved to be definitive. A comparison of the three groups was established with the non-dissected nerves. A significant statistical difference was obtained in the Groups $2(p=0.0002776)$ and $3(p=0.00346393)$, clearly demonstrating an increased risk of lesion in these groups. No difference was observed between Group 1 and the non-dissected nerves group. 
An actual improvement in the vocal performance was noted in Goup 1, especially regarding respiratory characteristics. On the other hand, the vocal performance worsened in Group 2 patients, and this deterioration persisted, in part, also during the late evaluations. In Group 3, there was a marked lowering of the highest frequencies, associated with a profound reduction in the vocal extension. These features were attributed to partial RELS lesions, which could not be detected by the electromiography.

In conclusion, the only effective way to prevent an iatrogenic lesion of the RELS during a thyroidectomy was, in this study, an objective and meticulous search of the nerve near the superior thyroid pole, using a nerve stimulator. 


\section{APÊNDICE 1 PROTOCOLOS DE ESTUDO}


10.1. PROTOCOLO DE ESTUDO ANATÔMICO RAMO EXTERNO DO NERVO LARÍNGEO SUPERIOR

Cadáver no....... Iniciais...... Sexo...... Idade...... Tireóide: Normal...... Nódulos LD...... Nódulos LE......

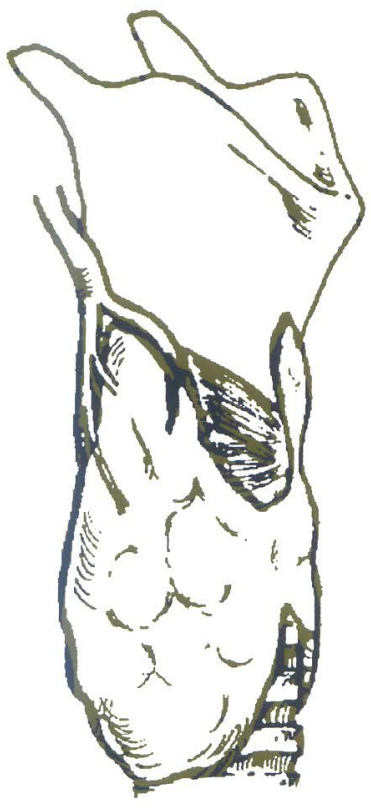

N. Laríngeo superior direito

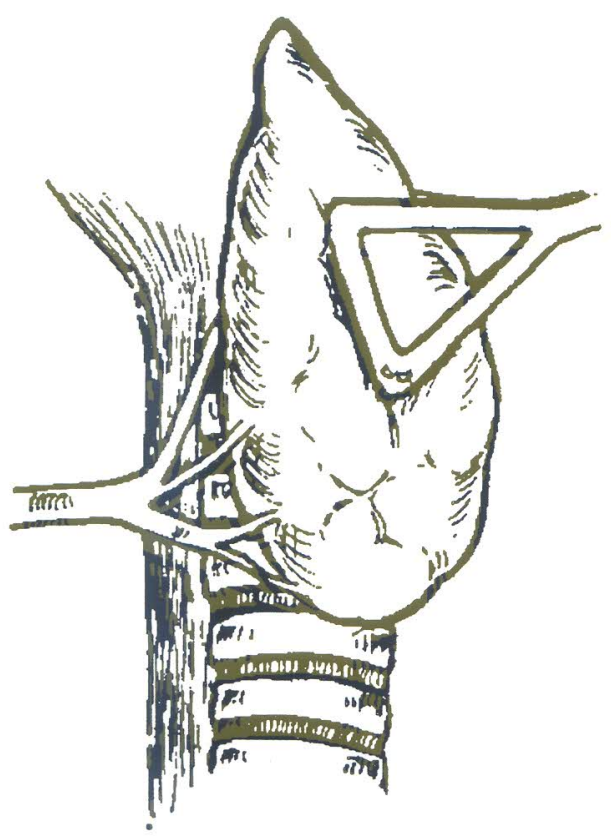

N. Laringeo inferior direito

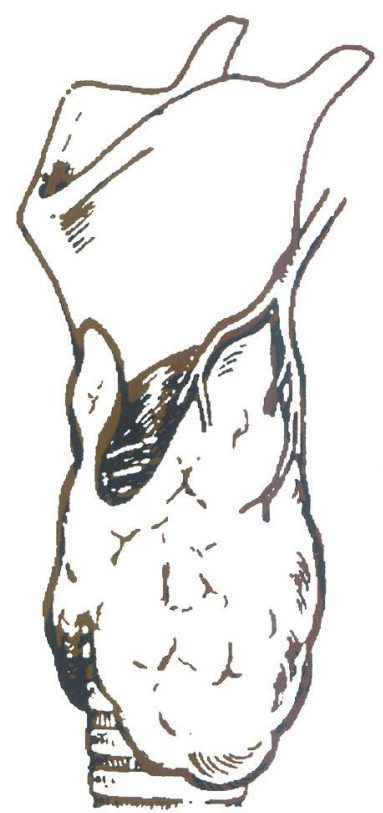

N. Laríngeo superior esquerdo

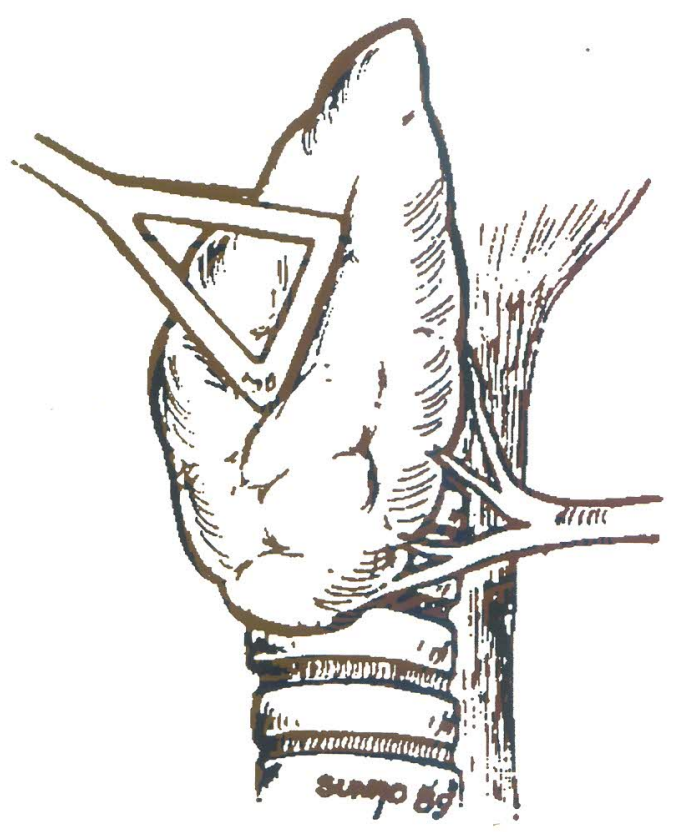

N. Laríngeo inferior esquerdo 


\title{
10.2. PROTOCOLO DE ESTUDO CLÍNICO;
}

\author{
LESÃO DO NERVO LARÍNGEO SUPERIOR
}

PROTOCOLO NO.

\section{IDENTIFICAÇÃO}

1. Nome 2.RG:

2. Idade 4. Sexo...... 5. Cor...... 6. Proc

7. Profissão 8. Endereço..

9. Telefone

\section{ANAMNESE}

1. Tempo de aparecimento: meses.

2. Mudança no caráter de crescimento: sim......;não......

3. Sintomas de compressão: sim......;não......

4. Outros: sim......;não...... (especificar: .............)

\section{III.EXAME FÍSICO}

1. Lobo direito: nódulos: sim......;não.......

2. Lobo esquerdo: nódulos: sim......;não......

3. Istmo: nódulos: sim......;não......

4. Outros nódulos: sim......;não......

5. Desvio de traquéia: sim......;não...... 


\section{DIAGNÓSTICO}

1. BUS LD .....; 2. BUS LE .....;3. BMS ......

4. CA ......

\section{AVALIAÇÃO FONOAUDILÓGICA PRÉ-OPERATÓRIA}

1. Ig:.......cps; 2. I:.......cps; 3. Ia:.......cps;

4. Taf:......s; 5. TFa:......s; 6. TFi.......s;

7. TFs:.......s; 8. TFz:.......s; 9. CPFA:.......s.

\section{CIRURGIA}

1. Data: ../../.. 2. Grupo: ......

3. Tempo operatório: .......min.

4. Lobectomia total D: sim......; não......

5. Lobectomia total E: sim.....; não......

6. Lobectomia parcial D: sim......; não......

7. Lobectomia parcial E: sim......; não......

8. Nodulectomia D: sim......; não......

9. Nodulectomia E: sim......; não......

(Só para o Grupo 1)

10. Tipo de RELS: n/ identif.: ......; Tipo 1: ......;

Tipo 2a: ......; Tipo 2b: ......

11. Tempo gasto para identificar o RELS: .......min.

12. Totalização: sim.....; não......

13. Reoperação: sim......; não...... 


\section{PATOLOGIA}

1. No.:

2. Dimensões da peça: .......cm x .......cm x .......cm.

3. Dimensões da peça (tot.): .......cm x .......cm x .......cm.

4. Dimensões da peça (reop.):.......cm x .......cm x .......cm.

5. Peso: .......g. 6. Peso (Tot.): ......g.

7. Peso (Reop.): .......g.

8. Tipo histológico: bócio adenomatoso: ......; adenoma folicular: ......; adenoma de Hürthle: ......; carcinoma papilífero: ......; carcinoma folicular: ......; carcinoma de Hürthle: ......; tireoidite de Hashimoto: ......; cisto hemorrágico: ......; outro: ......

\section{LARINGOSCOPIA INDIRETA PÓS-OPERATÓRIA IMEDIATA}

1. CVD: normal: ......; paresia: ......; paralisia: ......

2. CVE: normal: ......; paresia: ......; paralisia: ......

\section{AVALIAÇÃO FONOAUDIOLÓGICA PÓS-OPERATÓRIA IMEDIATA}

1. Ig: .......cps; 2. I: .......cps; 3. Ia: ......cps;

4. Taf: ......s; 5. TFa: ......s; 6. TFi: .......s;

7. TFs: ......s; 8. TFz: ......s; 9. CPFA: ......s.

\section{AVALIAÇÃO ELETROMIOGRÁFICA PÓS-OPERATÓRIA PRECOCE}

1. MCT direito: ativ. normal: ......; s/ atividade: ......

2. MCT esquerdo: ativ. normal: ......; s/ atividade: 
XI. AVALIAÇÃO FONOAUDIOLÓGICA PÓS-OPERATÓRIA TARDIA

1. Ig: ......cps; 2. I: ......cps; 3. Ia: ......cps;

4. Taf: ......s; 5. TFa: ......s; 6.TFi: ......s;

7. TFs: ......s; 8. TFz: ......s; 9. CPFA: ......s.

XII. AVALIAÇĀO ELETROMIOGRÁFICA PÓS-OPERATÓRIA TARDIA

1. MCT direito: ativ. normal: ......; s/ atividade: ......

2. MCT esquerdo: ativ. normal: ......; s/ atividade: ...... 


\section{APÊNDICE 2 DADOS REFERENTES AOS CASOS CLÍNICOS}


ID GRUPO IDADE SEXO COR DURAÇÃO COM- NÓD. NÓD. NÓD. DESV. DIAG. anos 1:m 1:b QUEIXA PRESSĀO LD LE IST. TRAQ. 1: BUS 2:f 2: nb meses $\quad 1: \operatorname{sim} \quad 1: \mathrm{s} \quad 1: \mathrm{s} \quad 1: \mathrm{s} \quad 1: \mathrm{s} \quad 2: \mathrm{BMS}$ 2: não $\quad 2: \mathrm{n} \quad 2: \mathrm{n} \quad 2: \mathrm{n} \quad 2: \mathrm{n}$

\begin{tabular}{|c|c|c|c|c|c|c|c|c|c|c|c|}
\hline 2 & 1 & 41 & 2 & 1 & 12 & 2 & 1 & 2 & 1 & 2 & 2 \\
\hline 4 & 1 & 37 & 2 & 1 & 96 & 2 & 1 & 2 & 2 & 2 & 1 \\
\hline 7 & 1 & 35 & 2 & 2 & 144 & 2 & 1 & 2 & 2 & 1 & 2 \\
\hline 8 & 1 & 32 & 2 & 1 & 2 & 2 & 1 & 2 & 2 & 2 & 1 \\
\hline 12 & 1 & 38 & 2 & 2 & 24 & 2 & 1 & 2 & 1 & 2 & 2 \\
\hline 14 & 1 & 25 & 2 & 1 & 60 & 1 & 1 & 2 & 2 & 1 & 1 \\
\hline $15^{\circ}$ & 1 & 35 & 2 & 1 & 36 & 2 & 1 & 2 & 2 & 2 & 1 \\
\hline 18 & 1 & 49 & 2 & 1 & 6 & 2 & 2 & 1 & 2 & 2 & 1 \\
\hline 23 & 1 & 37 & 2 & 1 & 24 & 2 & 1 & 2 & 2 & 2 & 1 \\
\hline 24 & 1 & 25 & 2 & 1 & 60 & 2 & 2 & 1 & 2 & 1 & 1 \\
\hline 44 & 1 & 14 & 1 & 1 & 8 & 2 & 1 & 2 & 2 & 2 & 1 \\
\hline 46 & 1 & 29 & 2 & 2 & 48 & 2 & 1 & 2 & 2 & 2 & 1 \\
\hline 48 & 1 & 22 & 2 & 1 & 24 & 2 & 2 & 1 & 2 & 2 & 1 \\
\hline 49 & 1 & 43 & 2 & 1 & 36 & 2 & 1 & 2 & 2 & 2 & 1 \\
\hline 61 & 1 & 17 & 2 & 1 & 12 & 2 & 1 & 2 & 2 & 1 & 1 \\
\hline 63 & 1 & 53 & 2 & 1 & 24 & 2 & 1 & 2 & 2 & 2 & 1 \\
\hline 65 & 1 & 25 & 2 & 1 & 36 & 2 & 1 & 2 & 2 & 2 & 1 \\
\hline 66 & 1 & 41 & 2 & 2 & 36 & 2 & 1 & 2 & 2 & 2 & 1 \\
\hline 67 & 1 & 30 & 2 & 2 & 24 & 2 & 1 & 2 & 2 & 2 & 1 \\
\hline 70 & 1 & 49 & 2 & 1 & 5 & 2 & 1 & 2 & 2 & 2 & 1 \\
\hline 33 & 1 & 55 & 2 & 1 & 60 & 2 & 2 & 1 & 2 & 2 & 1 \\
\hline 26 & 1 & 35 & 1 & 1 & 24 & 2 & 1 & 2 & 2 & 2 & 1 \\
\hline 85 & 1 & 35 & 2 & 1 & 144 & 2 & 1 & 2 & 2 & 1 & 1 \\
\hline 101 & 1 & 59 & 2 & 1 & 12 & 2 & 2 & 1 & 2 & 2 & 1 \\
\hline 90 & 1 & 44 & 2 & 1 & 60 & 2 & 2 & 1 & 2 & 2 & 1 \\
\hline 5 & 1 & 49 & 2 & 1 & 108 & 2 & 2 & 1 & 2 & 2 & 1 \\
\hline
\end{tabular}


ID GRUPO IDADE SEXO COR DURAÇÃO COM- NÓD. NÓD. NÓD. DESV. DIAG. anos 1: $\mathrm{m}$ 1:b QUEIXA PRESSÃO LD LE IST. TRAQ. 1: BUS $2: \mathrm{f} \quad 2: \mathrm{nb} \quad$ meses $\quad 1: \operatorname{sim} \quad 1: \mathrm{s} \quad 1: \mathrm{s} \quad 1: \mathrm{s} \quad 1: \mathrm{s} \quad 2: \mathrm{BMS}$ 2: não $\quad 2: n \quad 2: n \quad 2: n \quad 2: n$

\begin{tabular}{|c|c|c|c|c|c|c|c|c|c|c|c|}
\hline 1 & 2 & 60 & 2 & 2 & 168 & 2 & 1 & 2 & 2 & 2 & 1 \\
\hline 3 & 2 & 37 & 2 & 2 & 24 & 2 & 1 & 2 & 2 & 2 & 1 \\
\hline 17 & 2 & 52 & 2 & 2 & 240 & 2 & 1 & 2 & 2 & 1 & 2 \\
\hline 52 & 2 & 22 & 1 & 2 & 6 & 2 & 2 & 1 & 2 & 2 & 1 \\
\hline 62 & 2 & 28 & 2 & 2 & 24 & 2 & 1 & 2 & 2 & 1 & 1 \\
\hline 19 & 2 & 35 & 2 & 1 & 72 & 2 & 2 & 1 & 2 & 1 & 1 \\
\hline 57 & 2 & 46 & 2 & 2 & 4 & 2 & 2 & 1 & 2 & 2 & 1 \\
\hline 5 & 2 & 27 & 2 & 1 & 24 & 2 & 1 & 2 & 2 & 1 & 1 \\
\hline 6 & 2 & 57 & 2 & 1 & 8 & 2 & 2 & 1 & 2 & 2 & 1 \\
\hline 9 & 2 & 39 & 1 & 1 & 18 & 2 & 1 & 2 & 2 & 2 & 1 \\
\hline 10 & 2 & 24 & 2 & 1 & 3 & 2 & 2 & 1 & 2 & 2 & 1 \\
\hline 13 & 2 & 43 & 2 & 1 & 24 & 1 & 1 & 2 & 2 & 1 & 2 \\
\hline 16 & 2 & 36 & 2 & 1 & 96 & 1 & 2 & 1 & 2 & 1 & 1 \\
\hline 22 & 2 & 42 & 2 & 1 & 10 & 2 & 1 & 2 & 2 & 2 & 1 \\
\hline 25 & 2 & 35 & 2 & 1 & 48 & 2 & 1 & 2 & 2 & 2 & 1 \\
\hline 37 & 2 & 24 & 2 & 1 & 48 & 2 & 1 & 2 & 2 & 2 & 1 \\
\hline 41 & 2 & 43 & 2 & 1 & 36 & 2 & 2 & 1 & 2 & 2 & 1 \\
\hline 43 & 2 & 43 & 2 & 1 & 7 & 1 & 2 & 1 & 2 & 2 & 1 \\
\hline 47 & 2 & 37 & 2 & 1 & 6 & 2 & 2 & 1 & 2 & 2 & 1 \\
\hline 53 & 2 & 62 & 1 & 1 & 8 & 2 & 2 & 1 & 2 & 1 & 1 \\
\hline 54 & 2 & 32 & 2 & 2 & 12 & 2 & 1 & 2 & 2 & 1 & 1 \\
\hline 56 & 2 & 19 & 1 & 1 & 24 & 2 & 2 & 1 & 2 & 1 & 1 \\
\hline 64 & 2 & 29 & 2 & 1 & 15 & 2 & 1 & 2 & 2 & 2 & 1 \\
\hline 67 & 2 & 45 & 2 & 1 & 36 & 2 & 1 & 2 & 2 & 1 & 1 \\
\hline 68 & 2 & 50 & 2 & 1 & 72 & 2 & 2 & 1 & 2 & 2 & 1 \\
\hline
\end{tabular}


ID GRUPO IDADE SEXO COR DURAÇÃO COM- NÓD. NÓD. NÓD. DESV. DIAG. anos $1: \mathrm{m} \quad 1: \mathrm{b}$ QUEIXA PRESSĀO LD LE IST. TRAQ. 1: BUS

2:f 2: nb meses $1: \mathrm{sim} \quad 1: \mathrm{s} \quad 1: \mathrm{s} \quad 1: \mathrm{s} \quad 1: \mathrm{s} \quad 2: \mathrm{BMS}$ 2: não $\quad 2: \mathrm{n} \quad 2: \mathrm{n} \quad 2: \mathrm{n} \quad 2: \mathrm{n}$

\begin{tabular}{|c|c|c|c|c|c|c|c|c|c|c|c|}
\hline 69 & 3 & 33 & 1 & 2 & 5 & 2 & 1 & 2 & 2 & 1 & 1 \\
\hline 94 & 3 & 55 & 2 & 1 & 240 & 2 & 2 & 1 & 2 & 1 & 1 \\
\hline 58 & 3 & 46 & 2 & 1 & 12 & 2 & 2 & 1 & 2 & 2 & 1 \\
\hline 31 & 3 & 36 & 2 & 1 & 48 & 2 & 2 & 1 & 1 & 2 & 2 \\
\hline 45 & 3 & 25 & 2 & 1 & 36 & 2 & 2 & 1 & 2 & 1 & 1 \\
\hline 55 & 3 & 45 & 2 & 1 & 7 & 2 & 2 & 1 & 2 & 2 & 1 \\
\hline 59 & 3 & 46 & 2 & 1 & 120 & 2 & 1 & 2 & 2 & 2 & 1 \\
\hline 71 & 3 & 24 & 2 & 1 & 36 & 2 & 1 & 2 & 2 & 2 & 1 \\
\hline 73 & 3 & 39 & 2 & 2 & 120 & 2 & 2 & 1 & 2 & 1 & 1 \\
\hline 74 & 3 & 14 & 2 & 2 & 24 & 2 & 1 & 2 & 2 & 1 & 1 \\
\hline 76 & 3 & 14 & 2 & 1 & 4 & 2 & 1 & 2 & 2 & 2 & 1 \\
\hline 78 & 3 & 27 & 2 & 2 & 48 & 2 & 2 & 1 & 2 & 1 & 1 \\
\hline 79 & 3 & 36 & 2 & 1 & 30 & 2 & 2 & 1 & 2 & 2 & 1 \\
\hline 80 & 3 & 24 & 2 & 1 & 84 & 2 & 1 & 2 & 2 & 2 & 1 \\
\hline 86 & 3 & 20 & 2 & 1 & 6 & 2 & 2 & 1 & 2 & 1 & 1 \\
\hline 88 & 3 & 29 & 1 & 2 & 18 & 2 & 1 & 2 & 2 & 2 & 1 \\
\hline 91 & 3 & 44 & 2 & 1 & 6 & 2 & 2 & 1 & 2 & 1 & 1 \\
\hline 92 & 3 & 32 & 2 & 1 & 24 & 2 & 2 & 1 & 2 & 1 & 1 \\
\hline 93 & 3 & 53 & 2 & 1 & 36 & 2 & 1 & 2 & 2 & 2 & 1 \\
\hline 100 & 3 & 50 & 2 & 1 & 24 & 2 & 2 & 1 & 2 & 1 & 1 \\
\hline 98 & 3 & 44 & 2 & 1 & 36 & 2 & 1 & 2 & 2 & 2 & 1 \\
\hline 102 & 3 & 30 & 2 & 1 & 24 & 2 & 2 & 1 & 2 & 1 & 1 \\
\hline 99 & 3 & 49 & 2 & 1 & 180 & 1 & 1 & 2 & 2 & 1 & 1 \\
\hline 96 & 3 & 42 & 2 & 1 & 240 & 2 & 1 & 2 & 2 & 1 & 1 \\
\hline 89 & 3 & 59 & 1 & 1 & 36 & 2 & 2 & 1 & 2 & 2 & 1 \\
\hline
\end{tabular}




\begin{tabular}{|c|c|c|c|c|c|c|c|c|}
\hline $\begin{array}{l}\text { IGPRE } \\
\text { cps }\end{array}$ & $\begin{array}{l}\text { IPRE } \\
\text { cps }\end{array}$ & $\begin{array}{l}\text { IAPRE } \\
\text { cps }\end{array}$ & $\begin{array}{c}\text { TAFPRE } \\
\mathrm{S}\end{array}$ & $\begin{array}{c}\text { AFAPRE } \\
\mathrm{s}\end{array}$ & $\begin{array}{c}\text { TFIPRE } \\
\mathrm{s}\end{array}$ & $\begin{array}{c}\text { TFSPRE } \\
\mathrm{s}\end{array}$ & $\begin{array}{c}\text { TFZPRE } \\
\mathrm{s}\end{array}$ & CPFAPRE \\
\hline 202 & 230 & 260 & 5 & 14 & 10 & 14 & 14 & 11 \\
\hline 187 & 199 & 485 & 7 & 9 & 9 & 10 & 10 & 8 \\
\hline 153 & 192 & 360 & 8 & 10 & 13 & 15 & 15 & 12 \\
\hline 220 & 250 & 474 & 9 & 12 & 22 & 15 & 13 & 10 \\
\hline 200 & 240 & 570 & 7 & 9 & 14 & 13 & 12 & 11 \\
\hline 210 & 224 & 520 & 8 & 7 & 8 & 7 & 6 & 8 \\
\hline 220 & 240 & 745 & 12 & 12 & 14 & 12 & 11 & 7 \\
\hline 187 & 205 & 648 & 14 & 12 & 13 & 11 & 10 & 9 \\
\hline 227 & 265 & 502 & 5 & 9 & 10 & 9 & 8 & 8 \\
\hline 220 & 250 & 628 & 4 & 16 & 19 & 10 & 14 & 8 \\
\hline 200 & 230 & 340 & 10 & 19 & 20 & 20 & 18 & 14 \\
\hline 190 & 240 & 600 & 5 & 22 & 21 & 20 & 19 & 11 \\
\hline 203 & 216 & 715 & 8 & 9 & 11 & 10 & 9 & 13 \\
\hline 166 & 210 & 606 & 10 & 17 & 14 & 15 & 13 & 15 \\
\hline 227 & 248 & 603 & 9 & 13 & 15 & 14 & 13 & 9 \\
\hline 176 & 210 & 682 & 5 & 16 & 27 & 18 & 16 & 15 \\
\hline 205 & 241 & 808 & 11 & 17 & 15 & 16 & 14 & 8 \\
\hline 182 & 185 & 560 & 10 & 15 & 16 & 17 & 15 & 10 \\
\hline 170 & 195 & 720 & 8 & 4 & 7 & 10 & 9 & 14 \\
\hline 165 & 205 & 650 & 11 & 9 & 10 & 11 & 10 & 10 \\
\hline 185 & 209 & 450 & 5 & 7 & 7 & 8 & 6 & 14 \\
\hline 169 & 200 & 488 & 6 & 13 & 23 & 20 & 18 & 13 \\
\hline 190 & 227 & 780 & 10 & 10 & 9 & 16 & 15 & 10 \\
\hline 146 & 180 & 538 & 8 & 9 & 15 & 14 & 13 & 15 \\
\hline 190 & 205 & 720 & 14 & 12 & 17 & 24 & 20 & 20 \\
\hline 182 & 202 & 512 & 4 & 10 & 10 & 12 & 6 & 11 \\
\hline
\end{tabular}


IGPRE IPRE IAPRE TAFPRE AFAPRE TFIPRE TFSPRE TFZPRE CPFAPRE

\begin{tabular}{|c|c|c|c|c|c|c|c|c|}
\hline $\mathrm{cps}$ & cps & $\mathrm{cps}$ & s & S & $\mathrm{s}$ & $\mathrm{s}$ & $\mathrm{s}$ & \\
\hline 240 & 270 & 386 & 5 & 12 & 13 & 15 & 15 & 14 \\
\hline 200 & 260 & 742 & 22 & 22 & 24 & 27 & 27 & 17 \\
\hline 185 & 248 & 690 & 6 & 10 & 11 & 12 & 12 & 10 \\
\hline 210 & 240 & 560 & 15 & 19 & 25 & 22 & 10 & 20 \\
\hline 186 & 220 & 600 & 8 & 10 & 10 & 11 & 10 & 8 \\
\hline 180 & 205 & 340 & 5 & 14 & 10 & 11 & 10 & 15 \\
\hline 170 & 185 & 383 & 4 & 11 & 7 & 10 & 9 & 8 \\
\hline 228 & 240 & 589 & 8 & 11 & 15 & 15 & 13 & 11 \\
\hline 193 & 210 & 523 & 7 & 17 & 17 & 18 & 17 & 11 \\
\hline 115 & 124 & 305 & 13 & 17 & 23 & 22 & 21 & 12 \\
\hline 245 & 271 & 572 & 10 & 12 & 15 & 13 & 12 & 7 \\
\hline 205 & 212 & 460 & 4 & 9 & 9 & 7 & 6 & 10 \\
\hline 234 & 270 & 596 & 9 & 10 & 9 & 10 & 5 & 8 \\
\hline 202 & 275 & 683 & 6 & 18 & 18 & 15 & 13 & 7 \\
\hline 215 & 228 & 735 & 4 & 13 & 17 & 14 & 13 & 8 \\
\hline 242 & 252 & 740 & 6 & 9 & 14 & 15 & 14 & 10 \\
\hline 210 & 240 & 630 & 7 & 15 & 20 & 20 & 18 & 10 \\
\hline 193 & 218 & 582 & 7 & 10 & 10 & 15 & 11 & 12 \\
\hline 227 & 250 & 760 & 10 & 15 & 25 & 22 & 20 & 15 \\
\hline 105 & 123 & 380 & 4 & 16 & 23 & 22 & 20 & 7 \\
\hline 170 & 191 & 830 & 15 & 10 & 11 & 13 & 12 & 10 \\
\hline 127 & 139 & 480 & 4 & 5 & 8 & 10 & 10 & 9 \\
\hline 197 & 246 & 529 & 5 & 10 & 16 & 14 & 13 & 8 \\
\hline 206 & 224 & 603 & 10 & 15 & 21 & 20 & 18 & 22 \\
\hline 209 & 223 & 426 & 8 & 16 & 22 & 20 & 18 & 11 \\
\hline
\end{tabular}


IGPRE IPRE IAPRE TAFPRE AFAPRE TFIPRE TFSPRE TFZPRE CPFAPRE

\begin{tabular}{|c|c|c|c|c|c|c|c|c|}
\hline $\mathrm{cps}$ & $\mathrm{cps}$ & $\mathrm{cps}$ & $\mathrm{s}$ & $\mathrm{s}$ & $\mathrm{s}$ & $\mathrm{s}$ & $\mathrm{s}$ & \\
\hline 104 & 175 & 522 & 21 & 15 & 22 & 20 & 18 & 15 \\
\hline 145 & 216 & 635 & 6 & 15 & 16 & 22 & 13 & 13 \\
\hline 202 & 237 & 493 & 6 & 7 & 6 & 8 & 7 & 8 \\
\hline 189 & 226 & 800 & 6 & 12 & 13 & 11 & 10 & 12 \\
\hline 187 & 258 & 515 & 5 & 10 & 13 & 10 & 9 & 10 \\
\hline 196 & 244 & 775 & 15 & 22 & 22 & 18 & 16 & 18 \\
\hline 187 & 212 & 605 & 4 & 9 & 15 & 15 & 13 & 15 \\
\hline 160 & 215 & 654 & 8 & 10 & 18 & 14 & 13 & 14 \\
\hline 203 & 205 & 260 & 4 & 7 & 11 & 7 & 6 & 11 \\
\hline 200 & 236 & 711 & 7 & 7 & 10 & 10 & 9 & 12 \\
\hline 240 & 250 & 712 & 8 & 18 & 12 & 16 & 14 & 15 \\
\hline 140 & 165 & 770 & 16 & 10 & 18 & 12 & 10 & 18 \\
\hline 153 & 170 & 461 & 5 & 9 & 10 & 11 & 19 & 8 \\
\hline 203 & 225 & 660 & 18 & 13 & 15 & 15 & 15 & 13 \\
\hline 220 & 229 & 535 & 8 & 10 & 14 & 15 & 13 & 15 \\
\hline 106 & 118 & 660 & 15 & 14 & 21 & 25 & 17 & 21 \\
\hline 195 & 250 & 790 & 10 & 25 & 22 & 25 & 19 & 25 \\
\hline 205 & 220 & 593 & 5 & 14 & 10 & 17 & 8 & 15 \\
\hline 160 & 180 & 829 & 10 & 13 & 7 & 18 & 13 & 15 \\
\hline 146 & 180 & 538 & 8 & 9 & 15 & 14 & 13 & 15 \\
\hline 175 & 226 & 560 & 4 & 13 & 13 & 7 & 5 & 14 \\
\hline 174 & 214 & 738 & 7 & 7 & 10 & 9 & 15 & 13 \\
\hline 120 & 170 & 550 & 16 & 16 & 14 & 26 & 17 & 26 \\
\hline 198 & 204 & 708 & 8 & 17 & 19 & 12 & 10 & 13 \\
\hline 90 & 102 & 645 & 10 & 7 & 15 & 20 & 10 & 15 \\
\hline
\end{tabular}




\begin{tabular}{|c|c|c|c|c|c|c|c|}
\hline $\begin{array}{c}\text { OPERAÇÃO } \\
\text { 1: LTD+I } \\
\text { 2: LTE+I } \\
\text { 5: TT }\end{array}$ & $\begin{array}{c}\text { TEMPO } \\
\text { ANEST. } \\
\text { min. }\end{array}$ & $\begin{array}{c}\text { TEMPO P/ } \\
\text { PESQUISA } \\
\text { RELSD } \\
\text { min. }\end{array}$ & $\begin{array}{c}\text { TEMPO P/ } \\
\text { PESQUISA } \\
\text { RELSE } \\
\text { min. }\end{array}$ & $\begin{array}{c}\text { TIPO RELSD } \\
\text { 1: n/ident. } \\
2: 1\end{array}$ & $\begin{array}{l}\text { TIPO RELSE } \\
\text { 1: n/ident. } \\
\text { 3: } 2 \mathrm{a} \\
\text { 4: } 2 \mathrm{~b}\end{array}$ & $\begin{array}{l}\text { REOP } \\
\text { 3: LE } \\
4: \text { LD } \\
4: 2 b\end{array}$ & $\begin{array}{c}\text { TEMPO } \\
\text { ANEST. } \\
\text { REOP } \\
\text { min. }\end{array}$ \\
\hline 1 & 240 & - & - & 2 & - & - & - \\
\hline 1 & 195 & - & - & 3 & - & - & - \\
\hline 1 & 180 & 10 & - & 4 & - & - & - \\
\hline 1 & 220 & 12 & - & 2 & - & - & - \\
\hline 1 & 165 & 10 & - & 2 & - & - & - \\
\hline 1 & 210 & 50 & - & 1 & - & - & - \\
\hline 1 & 240 & 12 & - & 2 & - & - & - \\
\hline 2 & 240 & - & 15 & - & 2 & - & - \\
\hline 1 & 190 & 3 & - & 2 & - & - & - \\
\hline 2 & 195 & - & 12 & - & 2 & - & - \\
\hline 1 & 270 & 6 & - & 2 & - & - & - \\
\hline 1 & 180 & 8 & - & 2 & - & - & - \\
\hline 2 & 240 & - & 5 & - & 4 & - & - \\
\hline 5 & 300 & 16 & 2 & 3 & 2 & - & - \\
\hline 1 & 165 & 3 & - & 2 & - & - & - \\
\hline 1 & 220 & 6 & - & 2 & - & - & - \\
\hline 1 & 180 & 15 & - & 2 & - & - & - \\
\hline 2 & 180 & - & 2 & - & 4 & - & - \\
\hline 1 & 190 & 20 & - & 2 & - & - & - \\
\hline 1 & 220 & 8 & - & 2 & - & - & - \\
\hline 2 & 185 & - & 50 & - & 2 & - & - \\
\hline 5 & 225 & 12 & 3 & 2 & 3 & - & - \\
\hline 1 & 180 & 2 & - & 2 & - & - & - \\
\hline 2 & 180 & - & 1 & - & 4 & - & - \\
\hline 2 & 165 & - & 16 & - & 2 & - & - \\
\hline 2 & 215 & - & 38 & - & 1 & - & - \\
\hline
\end{tabular}




\begin{tabular}{|c|c|c|c|c|c|c|c|}
\hline $\begin{array}{c}\text { OPERAÇÃO } \\
\text { 1: LTD+I } \\
\text { 2: LTE+I } \\
\text { 5: TT }\end{array}$ & $\begin{array}{l}\text { TEMPO } \\
\text { ANEST. } \\
\text { min. }\end{array}$ & $\begin{array}{l}\text { TEMPO P/ } \\
\text { PESQUISA } \\
\text { RELSD } \\
\text { min. }\end{array}$ & $\begin{array}{c}\text { TEMPO P/ } \\
\text { PESQUISA } \\
\text { RELSE } \\
\text { min. }\end{array}$ & $\begin{array}{l}\text { TIPO RELSD } \\
\text { 1: n/ident. } \\
2: 1\end{array}$ & $\begin{array}{l}\text { TIPO RELSE } \\
\text { 1: n/ident. } \\
\text { 3: } 2 \mathrm{a} \\
4: 2 \mathrm{~b}\end{array}$ & $\begin{array}{l}\text { REOP } \\
\text { 3: LE } \\
4: \text { LD } \\
4: 2 b\end{array}$ & $\begin{array}{c}\text { TEMPO } \\
\text { ANEST. } \\
\text { REOP } \\
\text { min. }\end{array}$ \\
\hline 1 & 240 & - & - & - & - & - & - \\
\hline 5 & 300 & - & - & - & - & - & - \\
\hline 1 & 255 & - & - & - & - & - & - \\
\hline 2 & 150 & - & - & - & - & 4 & 150 \\
\hline 1 & 180 & - & - & - & - & - & - \\
\hline 2 & 240 & - & - & - & - & 4 & 165 \\
\hline 2 & 165 & - & - & - & - & - & - \\
\hline 1 & 255 & - & - & - & - & 3 & 165 \\
\hline 2 & 165 & - & - & - & - & - & - \\
\hline 1 & 190 & - & - & - & - & - & - \\
\hline 2 & 165 & - & - & - & - & - & - \\
\hline 1 & 220 & - & - & - & - & - & - \\
\hline 2 & 210 & - & - & - & - & 4 & 215 \\
\hline 1 & 150 & - & - & - & - & - & - \\
\hline 1 & 165 & - & - & - & - & - & - \\
\hline 1 & 180 & - & - & - & - & - & - \\
\hline 2 & 195 & - & - & - & - & - & - \\
\hline 2 & 165 & - & - & - & - & - & - \\
\hline 2 & 150 & - & - & - & - & - & - \\
\hline 2 & 165 & - & - & - & - & - & - \\
\hline 1 & 210 & - & - & - & - & - & - \\
\hline 2 & 180 & - & - & - & - & 4 & 220 \\
\hline 1 & 240 & - & - & - & - & - & - \\
\hline 1 & 180 & - & - & - & - & - & - \\
\hline 2 & 210 & - & - & - & - & - & - \\
\hline
\end{tabular}




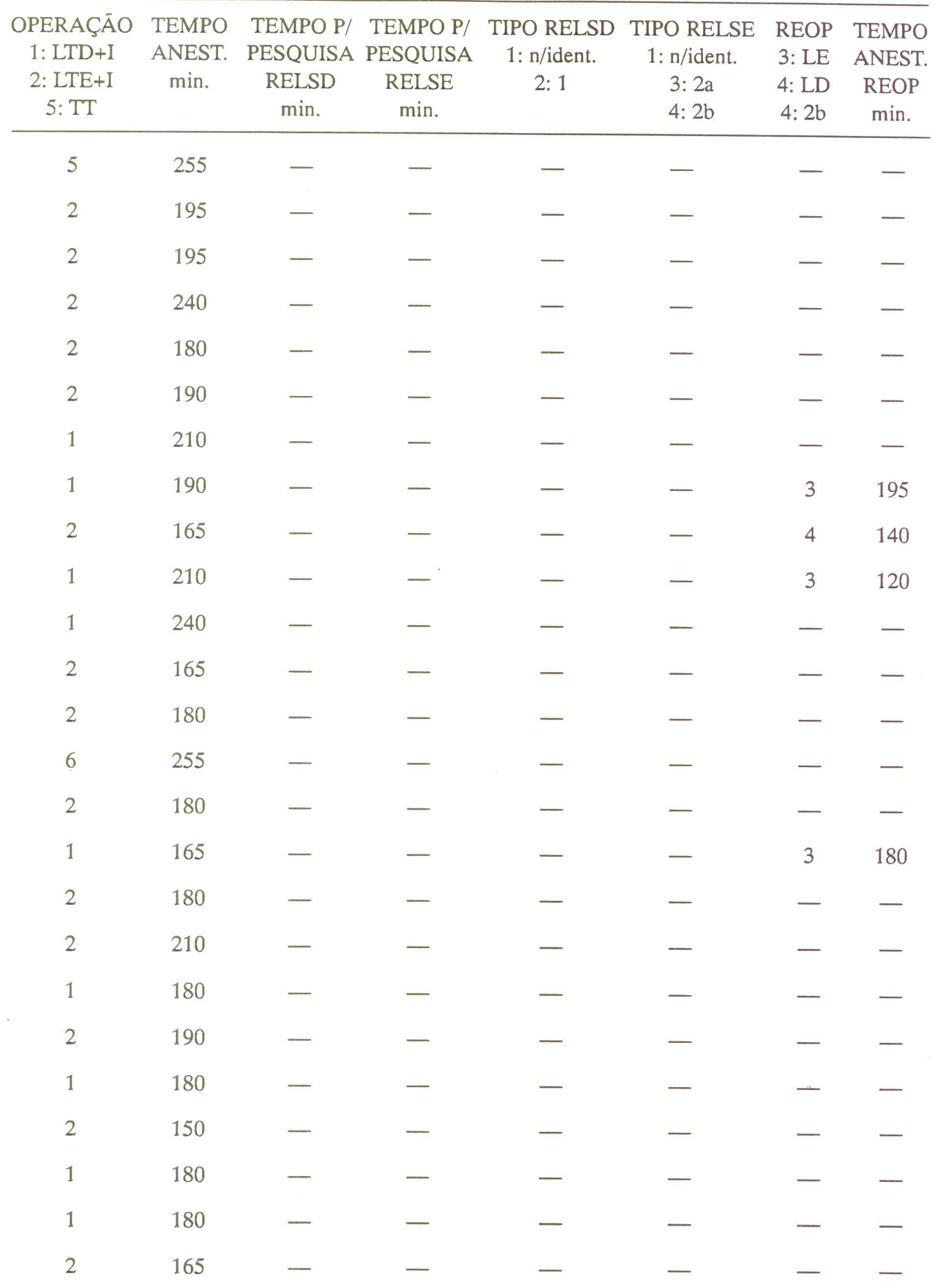


PEÇA PEÇA PEÇA PEÇA PEÇA PEÇA PEÇA PEÇA PEÇA PEÇA PEÇA PEÇA DIM1 DIM2 DIM3 (TOT) (TOT) (TOT) PESO (TOT) (REOP) (REOP) (REOP) (REOP) $\mathrm{mm} \mathrm{mm} \mathrm{mm}$ DIM1 DIM2 DIM3 g PESO DIM1 DIM2 DIM3 PESO $\mathrm{mm} \quad \mathrm{mm} \quad \mathrm{mm} \quad \mathrm{g} \quad \mathrm{mm} \quad \mathrm{mm} \quad \mathrm{mm} \quad \mathrm{g}$

\begin{tabular}{|c|c|c|c|c|c|c|c|c|c|c|c|}
\hline 40 & 40 & 25 & - & - & - & 20 & - & - & - & - & - \\
\hline 60 & 35 & 30 & - & - & - & 40 & - & - & - & - & - \\
\hline 50 & 50 & 40 & - & - & - & 40 & - & - & - & - & - \\
\hline 50 & 35 & 20 & - & - & - & 11 & - & - & - & - & - \\
\hline 70 & 45 & 25 & - & - & - & 32 & - & - & - & - & - \\
\hline 50 & 50 & 30 & - & - & - & 45 & - & - & - & - & - \\
\hline 65 & 30 & 25 & - & - & - & 25 & - & - & - & - & - \\
\hline 60 & 30 & 25 & - & - & - & 25 & - & - & - & - & - \\
\hline 60 & 30 & 30 & - & - & - & 30 & - & - & - & - & - \\
\hline 70 & 35 & 30 & - & - & - & 50 & - & - & - & - & - \\
\hline 40 & 25 & 10 & - & - & - & 10 & - & - & - & - & - \\
\hline 55 & 50 & 30 & - & - & - & 28 & - & - & - & - & - \\
\hline 30 & 30 & 10 & - & - & - & 17 & - & - & - & - & - \\
\hline 60 & 30 & 20 & 20 & 20 & 10 & 26 & 12 & - & - & - & - \\
\hline 55 & 35 & 20 & - & - & - & 20 & - & - & - & - & - \\
\hline 50 & 40 & 20 & - & - & - & 28 & - & - & - & - & - \\
\hline 70 & 40 & 30 & - & - & - & 44 & - & - & - & - & - \\
\hline 45 & 20 & 10 & - & - & - & 17 & - & - & - & - & - \\
\hline 60 & 30 & 15 & - & - & - & 20 & - & - & - & - & - \\
\hline 25 & 25 & 15 & - & - & - & 14 & - & - & - & - & - \\
\hline 45 & 30 & 15 & - & - & - & 26 & - & - & - & - & - \\
\hline 90 & 30 & 15 & 30 & 25 & 15 & 32 & 18 & - & - & - & - \\
\hline 55 & 30 & 20 & - & - & - & 20 & - & - & - & - & - \\
\hline$=0$ & 30 & 15 & - & - & - & 12 & - & - & - & - & - \\
\hline 50 & 30 & 15 & - & - & - & 22 & - & - & - & - & - \\
\hline 55 & 45 & 25 & - & - & - & 21 & - & - & - & - & - \\
\hline
\end{tabular}




\begin{tabular}{|c|c|c|c|c|c|c|c|c|c|c|c|}
\hline $\begin{array}{l}\text { PEÇA } \\
\text { DIM1 } \\
\text { mm }\end{array}$ & $\begin{array}{c}\text { PEÇA } \\
\text { DIM2 } \\
\text { mm }\end{array}$ & $\begin{array}{c}\text { PEÇA } \\
\text { DIM3 } \\
\text { mm }\end{array}$ & $\begin{array}{c}\text { PEÇA } \\
\text { (TOT) } \\
\text { DIM1 } \\
\text { mm }\end{array}$ & $\begin{array}{c}\text { PEÇA } \\
\text { (TOT) } \\
\text { DIM2 } \\
\text { mm }\end{array}$ & $\begin{array}{c}\text { PEÇA } \\
\text { (TOT) } \\
\text { DIM3 } \\
\text { mm }\end{array}$ & $\begin{array}{c}\text { PEÇA } \\
\text { PESO } \\
\mathrm{g}\end{array}$ & $\begin{array}{c}\text { PEÇA } \\
\text { (TOT) } \\
\text { PESO } \\
\text { g }\end{array}$ & $\begin{array}{c}\text { PEÇA } \\
\text { (REOP) } \\
\text { DIM1 } \\
\text { mm }\end{array}$ & $\begin{array}{c}\text { PEÇA } \\
\text { (REOP) } \\
\text { DIM2 } \\
\text { mm }\end{array}$ & $\begin{array}{c}\text { PEÇA } \\
\text { (REOP) } \\
\text { DIM3 } \\
\text { mm }\end{array}$ & $\begin{array}{c}\text { PEÇA } \\
\text { (REOP) } \\
\text { PESO } \\
\text { g }\end{array}$ \\
\hline 60 & 60 & 35 & - & - & - & 50 & - & - & - & - & - \\
\hline 80 & 50 & 40 & 40 & 40 & 25 & 40 & 15 & - & - & - & - \\
\hline 90 & 60 & 60 & - & - & - & 130 & - & - & - & - & - \\
\hline 45 & 35 & 35 & - & - & - & 35 & - & 35 & 25 & 20 & 20 \\
\hline 40 & 30 & 20 & - & - & - & 18 & - & - & - & - & - \\
\hline 60 & 50 & 40 & - & - & - & 32 & - & 40 & 30 & 15 & 15 \\
\hline 40 & 20 & 20 & - & - & - & 18 & - & - & - & - & - \\
\hline 40 & 30 & 20 & - & - & - & 18 & - & 20 & 20 & 10 & 13 \\
\hline 60 & 35 & 25 & - & - & - & 26 & - & - & - & - & - \\
\hline 70 & 55 & 5 & - & - & - & 30 & - & - & - & - & - \\
\hline 40 & 30 & 25 & - & - & - & 20 & - & - & - & - & - \\
\hline 60 & 40 & 40 & - & - & - & 25 & - & - & - & - & - \\
\hline 60 & 20 & 20 & - & - & - & 20 & - & 40 & 20 & 10 & 16 \\
\hline 50 & 40 & 30 & - & - & - & 20 & - & - & - & - & - \\
\hline 60 & 30 & 25 & - & - & - & 23 & - & - & - & - & - \\
\hline 80 & 20 & 10 & - & - & - & 12 & - & - & - & - & - \\
\hline 50 & 30 & 27 & - & - & - & 28 & - & - & - & - & - \\
\hline 45 & 45 & 30 & - & - & - & 15 & - & - & - & - & - \\
\hline 50 & 25 & 10 & - & - & - & 10 & - & - & - & - & - \\
\hline 50 & 50 & 30 & - & - & - & 38 & - & - & - & - & - \\
\hline 75 & 55 & 15 & - & - & - & 25 & - & - & - & - & - \\
\hline 90 & 70 & 50 & - & - & - & 44 & - & 40 & 40 & 5 & 16 \\
\hline 65 & 45 & 25 & - & - & - & 35 & - & - & - & - & - \\
\hline 55 & 35 & 25 & - & - & - & 30 & - & - & - & - & - \\
\hline 60 & 40 & 25 & - & - & - & 25 & - & - & - & - & - \\
\hline
\end{tabular}




\begin{tabular}{|c|c|c|c|c|c|c|c|c|c|c|c|}
\hline $\begin{array}{l}\text { PEÇA } \\
\text { DIM1 } \\
\text { mm }\end{array}$ & $\begin{array}{c}\text { PEÇA } \\
\text { DIM2 } \\
\text { mm }\end{array}$ & $\begin{array}{c}\text { PEÇA } \\
\text { DIM3 } \\
\text { mm }\end{array}$ & $\begin{array}{c}\text { PEÇA } \\
\text { (TOT) } \\
\text { DIM1 } \\
\text { mm }\end{array}$ & $\begin{array}{c}\text { PEÇA } \\
\text { (TOT) } \\
\text { DIM2 } \\
\text { mm }\end{array}$ & $\begin{array}{c}\text { PEÇA } \\
\text { (TOT) } \\
\text { DIM3 } \\
\text { mm }\end{array}$ & $\begin{array}{c}\text { PEÇA } \\
\text { PESO } \\
\text { g }\end{array}$ & $\begin{array}{c}\text { PEÇA } \\
\text { (TOT) } \\
\text { PESO } \\
\text { g }\end{array}$ & $\begin{array}{c}\text { PEÇA } \\
\text { (REOP) } \\
\text { DIM1 } \\
\text { mm }\end{array}$ & $\begin{array}{c}\text { PEÇA } \\
\text { (REOP) } \\
\text { DIM2 } \\
\mathrm{mm}\end{array}$ & $\begin{array}{c}\text { PEÇA } \\
\text { (REOP) } \\
\text { DIM3 } \\
\text { mm }\end{array}$ & $\begin{array}{c}\text { PEÇA } \\
\text { (REOP) } \\
\text { PESO } \\
\mathrm{g}\end{array}$ \\
\hline 10 & 50 & 15 & 30 & 20 & 10 & 30 & 11 & - & - & - & - \\
\hline 10 & 80 & 60 & - & - & - & 230 & - & - & - & - & - \\
\hline 55 & 45 & 30 & - & - & - & 28 & - & - & - & - & - \\
\hline 35 & 30 & 10 & - & - & - & 15 & - & - & - & - & - \\
\hline 80 & 40 & 20 & - & - & - & 30 & - & - & - & - & - \\
\hline 55 & 40 & 20 & - & - & - & 25 & - & - & - & - & - \\
\hline 50 & 50 & 30 & - & - & - & 35 & - & - & - & - & - \\
\hline 35 & 30 & 20 & - & - & - & 20 & - & 40 & 25 & 15 & 15 \\
\hline 55 & 45 & 30 & - & - & - & 30 & - & 30 & 20 & 15 & 12 \\
\hline 50 & 40 & 40 & - & - & - & 26 & - & 30 & 30 & 10 & 10 \\
\hline 40 & 40 & 20 & - & - & - & 22 & - & - & - & - & - \\
\hline 10 & 70 & 35 & - & - & - & 52 & - & - & - & - & - \\
\hline 30 & 30 & 30 & - & - & - & 20 & - & - & - & - & - \\
\hline 80 & 40 & 30 & 40 & 30 & 20 & 48 & 20 & - & - & - & - \\
\hline 40 & 30 & 20 & - & - & - & 24 & - & - & - & - & - \\
\hline 80 & 50 & 15 & - & - & - & 34 & - & 40 & 20 & 10 & 12 \\
\hline 60 & 40 & 15 & - & - & - & 22 & - & - & - & - & - \\
\hline 50 & 45 & 30 & - & - & - & 40 & - & - & - & - & - \\
\hline 50 & 15 & 15 & - & - & - & 15 & - & - & - & - & - \\
\hline 70 & 40 & 10 & - & - & - & 20 & - & - & - & - & - \\
\hline 50 & 20 & 10 & - & - & - & 24 & - & - & - & - & - \\
\hline 50 & 30 & 30 & - & - & - & 20 & - & - & - & - & - \\
\hline 60 & 50 & 15 & - & - & - & 30 & - & - & - & - & - \\
\hline 55 & 30 & 15 & - & - & - & 30 & - & - & - & - & - \\
\hline 60 & 50 & 40 & - & - & - & 30 & - & - & - & - & - \\
\hline
\end{tabular}




\begin{tabular}{|c|c|c|c|c|}
\hline $\begin{array}{l}\text { 1: bócio ad. 2: ad. fol. } \\
\text { 3: ad. Hürthle 4: cisto } \\
\text { hem. 5: tir. Hashim. } \\
\text { 6: ca p. 7: ca 8: ca Hür. }\end{array}$ & $\begin{array}{l}\text { EMG PO } \\
\text { PREC MCTD } \\
\text { 1: ativ. n1 } \\
\text { 2: s/ativ. }\end{array}$ & $\begin{array}{l}\text { EMG PO } \\
\text { PREC MCTE } \\
\text { 1: ativ. m1 } \\
\text { 2: s/ativ. }\end{array}$ & $\begin{array}{l}\text { EMG PO } \\
\text { TARD MCTD } \\
\text { 1: ativ. } n 1 \\
\text { 2: s/ ativ. }\end{array}$ & $\begin{array}{l}\text { EMG PO } \\
\text { TARD MCTE } \\
\text { 1: ativ. n1 } \\
\text { 2: s/ ativ. }\end{array}$ \\
\hline 1 & 1 & 1 & - & - \\
\hline 1 & 1 & 1 & - & - \\
\hline 1 & 1 & 1 & - & - \\
\hline 1 & 1 & 1 & - & - \\
\hline 1 & 1 & 1 & - & - \\
\hline 1 & 1 & 1 & - & - \\
\hline 1 & 1 & 1 & - & - \\
\hline 1 & 1 & 1 & - & - \\
\hline 1 & 1 & 1 & - & - \\
\hline 1 & 1 & 1 & - & - \\
\hline 1 & 1 & 1 & - & - \\
\hline 1 & 1 & 1 & - & - \\
\hline 1 & 1 & 1 & - & - \\
\hline 6 & 1 & 1 & - & - \\
\hline 1 & 1 & 1 & - & - \\
\hline 3 & 1 & 1 & - & - \\
\hline 1 & 1 & 1 & - & - \\
\hline 1 & 1 & 1 & - & - \\
\hline 1 & 1 & 1 & - & - \\
\hline 1 & 1 & 1 & - & - \\
\hline 1 & 1 & 1 & - & - \\
\hline 6 & 1 & 1 & - & - \\
\hline 1 & 1 & 1 & - & - \\
\hline 1 & 1 & 1 & - & - \\
\hline 1 & 1 & 1 & - & - \\
\hline 1 & 1 & 1 & - & - \\
\hline
\end{tabular}




\begin{tabular}{|c|c|c|c|c|}
\hline $\begin{array}{l}\text { 1: bócio ad. 2: ad. fol. } \\
\text { 3: ad. Hürthle 4: cisto } \\
\text { hem. 5: tir. Hashim. } \\
\text { 6: ca p. 7: ca 8: ca Hür. }\end{array}$ & $\begin{array}{l}\text { EMG PO } \\
\text { PREC MCTD } \\
\text { 1: ativ. n1 } \\
\text { 2: s/ativ. }\end{array}$ & $\begin{array}{c}\text { EMG PO } \\
\text { PREC MCTE } \\
\text { 1: ativ. m1 } \\
\text { 2: s/ ativ. }\end{array}$ & $\begin{array}{l}\text { EMG PO } \\
\text { TARD MCTD } \\
\text { 1: ativ. n1 } \\
\text { 2: s/ ativ. }\end{array}$ & $\begin{array}{c}\text { EMG PO } \\
\text { TARD MCTE } \\
\text { 1: ativ. n1 } \\
\text { 2: s/ ativ. }\end{array}$ \\
\hline 1 & 2 & 1 & 1 & 1 \\
\hline 6 & 2 & 1 & 2 & 1 \\
\hline 1 & 2 & 1 & 2 & 1 \\
\hline 8 & 1 & 2 & 1 & 1 \\
\hline 1 & 2 & 1 & 2 & 1 \\
\hline 7 & 1 & 2 & 1 & 2 \\
\hline 2 & 1 & 2 & 1 & 1 \\
\hline 7 & 1 & 1 & - & - \\
\hline 1 & 1 & 1 & - & - \\
\hline 1 & 1 & 1 & - & - \\
\hline 1 & 1 & 1 & - & - \\
\hline 1 & 1 & 1 & - & - \\
\hline 6 & 1 & 1 & - & - \\
\hline 1 & 1 & 1 & - & - \\
\hline 1 & 1 & 1 & - & - \\
\hline 1 & 1 & 1 & - & - \\
\hline 1 & 1 & 1 & - & - \\
\hline 1 & 1 & 1 & - & - \\
\hline 1 & 1 & 1 & - & - \\
\hline 1 & 1 & 1 & - & - \\
\hline 1 & 1 & 1 & - & - \\
\hline 7 & 1 & 1 & - & - \\
\hline 1 & 1 & 1 & - & - \\
\hline 2 & 1 & 1 & - & - \\
\hline 4 & 1 & 1 & - & - \\
\hline
\end{tabular}




\begin{tabular}{|c|c|c|c|c|}
\hline $\begin{array}{l}\text { 1: bócio ad. 2: ad. fol. } \\
\text { 3: ad. Hürthle 4: cisto } \\
\text { hem. 5: tir. Hashim. } \\
\text { 6: ca p. 7: ca 8: ca Hür. }\end{array}$ & $\begin{array}{c}\text { EMG PO } \\
\text { PREC MCTD } \\
\text { 1: ativ. n1 } \\
\text { 2: s/ ativ. }\end{array}$ & $\begin{array}{c}\text { EMG PO } \\
\text { PREC MCTE } \\
\text { 1: ativ. } \mathrm{m} 1 \\
\text { 2: s/ ativ. }\end{array}$ & $\begin{array}{c}\text { EMG PO } \\
\text { TARD MCTD } \\
\text { 1: ativ. n1 } \\
\text { 2: s/ativ. }\end{array}$ & $\begin{array}{c}\text { EMG PO } \\
\text { TARD MCTE } \\
\text { 1: ativ. } \mathrm{n} 1 \\
\text { 2: s/ ativ. }\end{array}$ \\
\hline 6 & 2 & 1 & - & - \\
\hline 1 & 1 & 1 & - & - \\
\hline 1 & 1 & 2 & 1 & 1 \\
\hline 5 & 1 & 1 & - & - \\
\hline 2 & 1 & 1 & - & - \\
\hline 1 & 1 & 1 & - & - \\
\hline 1 & 1 & 1 & - & - \\
\hline 7 & 1 & 1 & - & - \\
\hline 7 & 1 & 1 & - & - \\
\hline 7 & 1 & 1 & - & - \\
\hline 2 & 1 & 1 & - & - \\
\hline 1 & 1 & 1 & - & - \\
\hline 1 & 1 & 1 & - & - \\
\hline 1 & 1 & 1 & - & - \\
\hline 1 & 1 & 1 & - & - \\
\hline 6 & 1 & 1 & - & - \\
\hline 4 & 1 & 1 & - & - \\
\hline 1 & 1 & 1 & - & - \\
\hline 1 & 1 & 1 & - & - \\
\hline 1 & 1 & 1 & - & - \\
\hline 1 & 1 & 1 & - & - \\
\hline 2 & 1 & 1 & - & - \\
\hline 1 & 1 & 1 & - & - \\
\hline 1 & 1 & 1 & - & - \\
\hline 1 & 1 & 2 & 1 & 1 \\
\hline
\end{tabular}




\begin{tabular}{|c|c|c|c|c|c|c|c|c|}
\hline $\begin{array}{l}\text { IGPOSI } \\
\text { cps }\end{array}$ & $\begin{array}{l}\text { IPOSI } \\
\mathrm{cps}\end{array}$ & $\begin{array}{c}\text { IAPOSI } \\
\mathrm{cps}\end{array}$ & $\begin{array}{c}\text { TAFPOSI } \\
\mathrm{s}\end{array}$ & $\begin{array}{c}\text { TFAPOSI } \\
\mathrm{s}\end{array}$ & $\begin{array}{c}\text { TFIPOSI } \\
\mathrm{s}\end{array}$ & $\begin{array}{l}\text { TFSPOSI } \\
\mathrm{s}\end{array}$ & $\begin{array}{l}\text { TFZPOSI } \\
\mathrm{s}\end{array}$ & CPFAPOSI \\
\hline 220 & 250 & 433 & 5 & 14 & 12 & 16 & 16 & 12 \\
\hline 190 & 200 & 618 & 7 & 16 & 15 & 17 & 17 & 13 \\
\hline 170 & 190 & 274 & 9 & 13 & 13 & 17 & 16 & 10 \\
\hline 225 & 240 & 540 & 7 & 20 & 10 & 14 & 12 & 11 \\
\hline 190 & 250 & 735 & 12 & 15 & 15 & 16 & 14 & 12 \\
\hline 222 & 225 & 740 & 12 & 13 & 15 & 13 & 12 & 12 \\
\hline 243 & 257 & 800 & 18 & 22 & 22 & 20 & 18 & 10 \\
\hline 195 & 240 & 540 & 10 & 10 & 11 & 13 & 12 & 12 \\
\hline 230 & 260 & 526 & 7 & 9 & 10 & 10 & 9 & 9 \\
\hline 199 & 228 & 628 & 6 & 18 & 15 & 14 & 16 & 9 \\
\hline 124 & 160 & 457 & 17 & 15 & 18 & 19 & 16 & 13 \\
\hline 200 & 230 & 715 & 10 & 14 & 18 & 17 & 16 & 12 \\
\hline 210 & 240 & 703 & 7 & 9 & 10 & 8 & 8 & 12 \\
\hline 180 & 213 & 600 & 16 & 14 & 11 & 13 & 12 & 16 \\
\hline 230 & 262 & 660 & 5 & 15 & 18 & 16 & 17 & 12 \\
\hline 166 & 204 & 630 & 9 & 13 & 20 & 19 & 15 & 16 \\
\hline 221 & 232 & 758 & 10 & 17 & 16 & 15 & 14 & 12 \\
\hline 160 & 178 & 390 & 10 & 21 & 23 & 20 & 19 & 12 \\
\hline 155 & 189 & 635 & 11 & 10 & 9 & 14 & 12 & 13 \\
\hline 168 & 196 & 693 & 7 & 9 & 18 & 15 & 14 & 15 \\
\hline 170 & 178 & 380 & 7 & 12 & 19 & 11 & 13 & 19 \\
\hline 111 & 205 & 497 & 7 & 15 & 25 & 23 & 20 & 14 \\
\hline 210 & 230 & 637 & 12 & 9 & 10 & 15 & 12 & 8 \\
\hline 175 & 234 & 512 & 10 & 13 & 14 & 51 & 12 & 14 \\
\hline 180 & 221 & 801 & 11 & 10 & 8 & 25 & 12 & 14 \\
\hline 175 & 226 & 404 & 8 & 13 & 12 & 15 & 14 & 12 \\
\hline
\end{tabular}




\begin{tabular}{|c|c|c|c|c|c|c|c|c|}
\hline $\begin{array}{c}\text { IGPOSI } \\
\mathrm{cps}\end{array}$ & $\begin{array}{l}\text { IPOSI } \\
\text { cps }\end{array}$ & $\begin{array}{c}\text { IAPOSI } \\
\mathrm{cps}\end{array}$ & $\begin{array}{c}\text { TAFPOSI } \\
\mathrm{s}\end{array}$ & $\begin{array}{c}\text { TFAPOSI } \\
\mathrm{s}\end{array}$ & $\begin{array}{c}\text { TFIPOSI } \\
\mathrm{s}\end{array}$ & $\begin{array}{c}\text { TFSPOSI } \\
\mathrm{s}\end{array}$ & $\begin{array}{c}\text { TFZPOSI } \\
\mathrm{s}\end{array}$ & CPFAPOSI \\
\hline 230 & 266 & 269 & 7 & 9 & 10 & 12 & 10 & 9 \\
\hline 150 & 170 & 229 & 14 & 7 & 13 & 15 & 7 & 6 \\
\hline 190 & 216 & 406 & 5 & 9 & 10 . & 9 & 8 & 8 \\
\hline 186 & 205 & 487 & 10 & 12 & 12 & 13 & 11 & 10 \\
\hline 190 & 207 & 478 & 10 & 16 & 17 & 10 & 9 & 8 \\
\hline 160 & 173 & 288 & 6 & 14 & 17 & 16 & 15 & 10 \\
\hline 170 & 190 & 247 & 5 & 18 & 14 & 14 & 14 & 10 \\
\hline 223 & 230 & 635 & 9 & 12 & 16 & 17 & 15 & 12 \\
\hline 200 & 215 & 528 & 7 & 13 & 13 & 14 & 14 & 11 \\
\hline 124 & 150 & 304 & 12 & 22 & 22 & 20 & 19 & 11 \\
\hline 250 & 290 & 600 & 17 & 18 & 15 & 16 & 16 & 11 \\
\hline 230 & 250 & 635 & 4 & 9 & 9 & 8 & 7 & 11 \\
\hline 218 & 288 & 600 & 8 & 16 & 22 & 20 & 18 & 12 \\
\hline 210 & 250 & 750 & 12 & 24 & 20 & 22 & 20 & 9 \\
\hline 205 & 222 & 624 & 7 & 13 & 17 & 15 & 14 & 9 \\
\hline 192 & 213 & 685 & 7 & 12 & 20 & 19 & 18 & 14 \\
\hline 205 & 248 & 634 & 8 & 18 & 22 & 19 & 19 & 11 \\
\hline 163 & 215 & 620 & 8 & 16 & 16 & 17 & 15 & 18 \\
\hline 240 & 250 & 790 & 12 & 17 & 28 & 24 & 22 & 15 \\
\hline 78 & 180 & 390 & 5 & 10 & 15 & 20 & 17 & 8 \\
\hline 154 & 194 & 616 & 12 & 11 & 12 & 14 & 11 & 9 \\
\hline 128 & 131 & 459 & 14 & 12 & 12 & 13 & 11 & 11 \\
\hline 159 & 206 & 450 & 7 & 7 & 13 & 12 & 12 & 8 \\
\hline 211 & 255 & 534 & 13 & 16 & 23 & 22 & 20 & 25 \\
\hline 195 & 220 & 287 & 8 & 12 & 15 & 18 & 16 & 11 \\
\hline
\end{tabular}




\begin{tabular}{|c|c|c|c|c|c|c|c|c|}
\hline $\begin{array}{l}\text { IGPOSI } \\
\text { cps }\end{array}$ & $\begin{array}{l}\text { IPOSI } \\
\mathrm{cps}\end{array}$ & $\begin{array}{l}\text { IAPOSI } \\
\text { cps }\end{array}$ & $\begin{array}{c}\text { TAFPOSI } \\
\mathrm{s}\end{array}$ & $\begin{array}{c}\text { TFAPOSI } \\
\mathrm{s}\end{array}$ & $\begin{array}{l}\text { TFIPOSI } \\
\mathrm{s}\end{array}$ & $\begin{array}{c}\text { TFSPOSI } \\
\mathrm{s}\end{array}$ & $\begin{array}{l}\text { TFZPOSI } \\
\mathrm{s}\end{array}$ & CPFAPOSI \\
\hline 85 & 90 & 300 & 20 & 17 & 20 & 19 & 17 & 20 \\
\hline 105 & 160 & 404 & 7 & 10 & 8 & 15 & 12 & 12 \\
\hline 190 & 220 & 370 & 4 & 4 & 4 & 5 & 5 & 7 \\
\hline 163 & 246 & 576 & 10 & 18 & 18 & 17 & 16 & 15 \\
\hline 160 & 209 & 520 & 7 & 13 & 12 & 15 & 12 & 11 \\
\hline 208 & 230 & 600 & 17 & 15 & 25 & 20 & 18 & 10 \\
\hline 175 & 220 & 540 & 8 & 4 & 6 & 10 & 11 & 10 \\
\hline 180 & 255 & 715 & 7 & 15 & 28 & 23 & 18 & 20 \\
\hline 181 & 204 & 236 & 4 & 14 & 13 & 8 & 7 & 12 \\
\hline 208 & 262 & 750 & 15 & 7 & 15 & 18 & 9 & 13 \\
\hline 240 & 258 & 650 & 7 & 15 & 13 & 19 & 10 & 20 \\
\hline 142 & 164 & 544 & 8 & 13 & 14 & 15 & 9 & 11 \\
\hline 146 & 175 & 337 & 4 & 9 & 14 & 18 & 12 & 10 \\
\hline 183 & 202 & 604 & 14 & 13 & 18 & 17 & 18 & 20 \\
\hline 215 & 260 & 534 & 10 & 18 & 21 & 16 & 14 & 15 \\
\hline 117 & 124 & 532 & 12 & 15 & 18 & 21 & 20 & 18 \\
\hline 206 & 206 & 468 & 10 & 17 & 18 & 26 & 18 & 17 \\
\hline 216 & 238 & 497 & 4 & 12 & 16 & 15 & 10 & 13 \\
\hline 124 & 155 & 306 & 10 & 8 & 15 & 15 & 5 & 10 \\
\hline 175 & 234 & 512 & 10 & 13 & 14 & 14 & 15 & 12 \\
\hline 205 & 246 & 540 & 5 & 10 & 12 & 12 & 7 & 9 \\
\hline 182 & 246 & 697 & 10 & 14 & 18 & 10 & 19 & 14 \\
\hline 121 & 178 & 604 & 17 & 23 & 30 & 28 & 24 & 23 \\
\hline 200 & 210 & 707 & 9 & 12 & 14 & 8 & 6 & 11 \\
\hline 80 & 100 & 404 & 12 & 13 & 8 & 12 & 4 & 11 \\
\hline
\end{tabular}


IGPOST IPOST IAPOST TAFPOST TFAPOST TFIPOST TFSPOST TFZPOST CPFAPOST cps cps cps

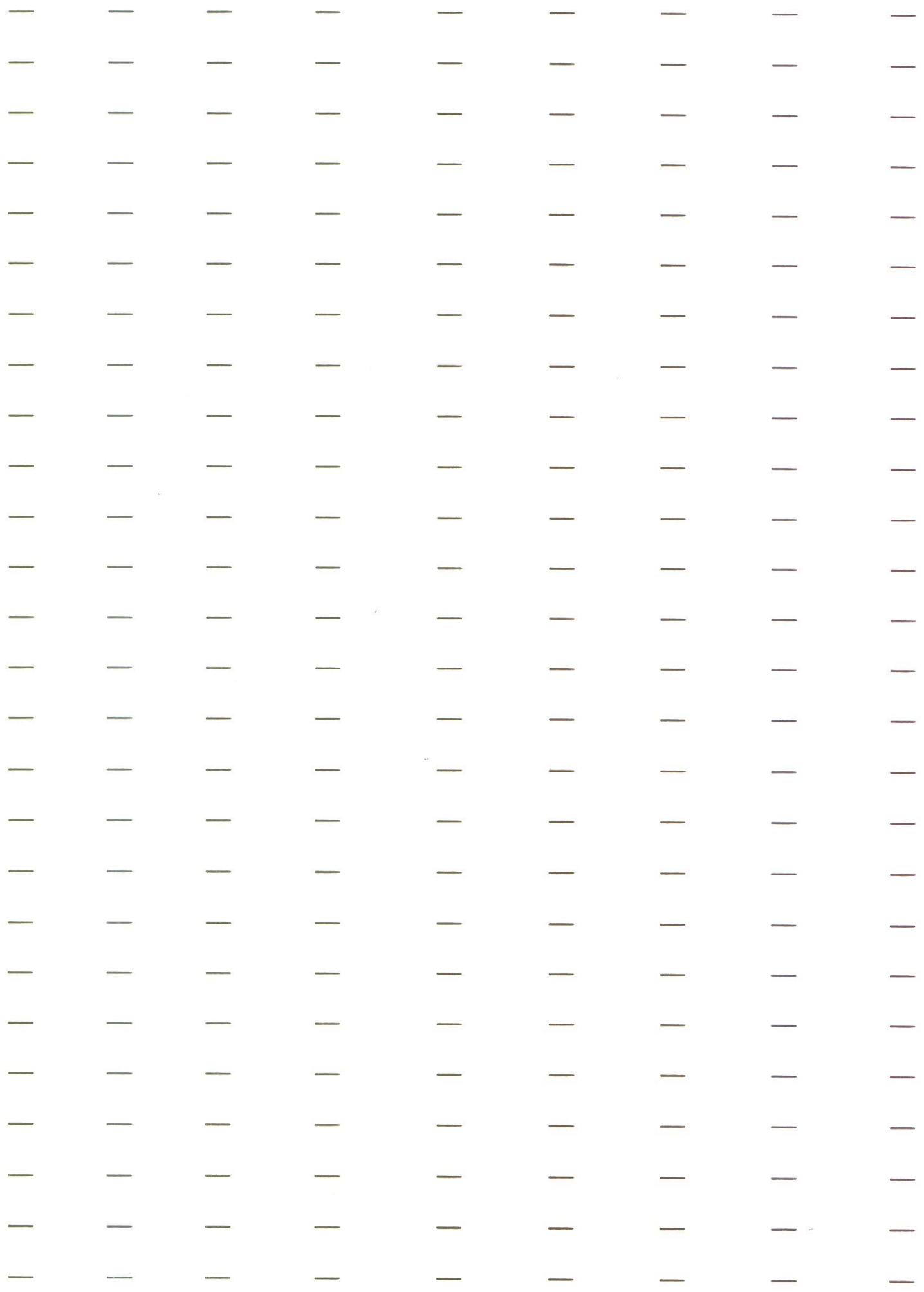




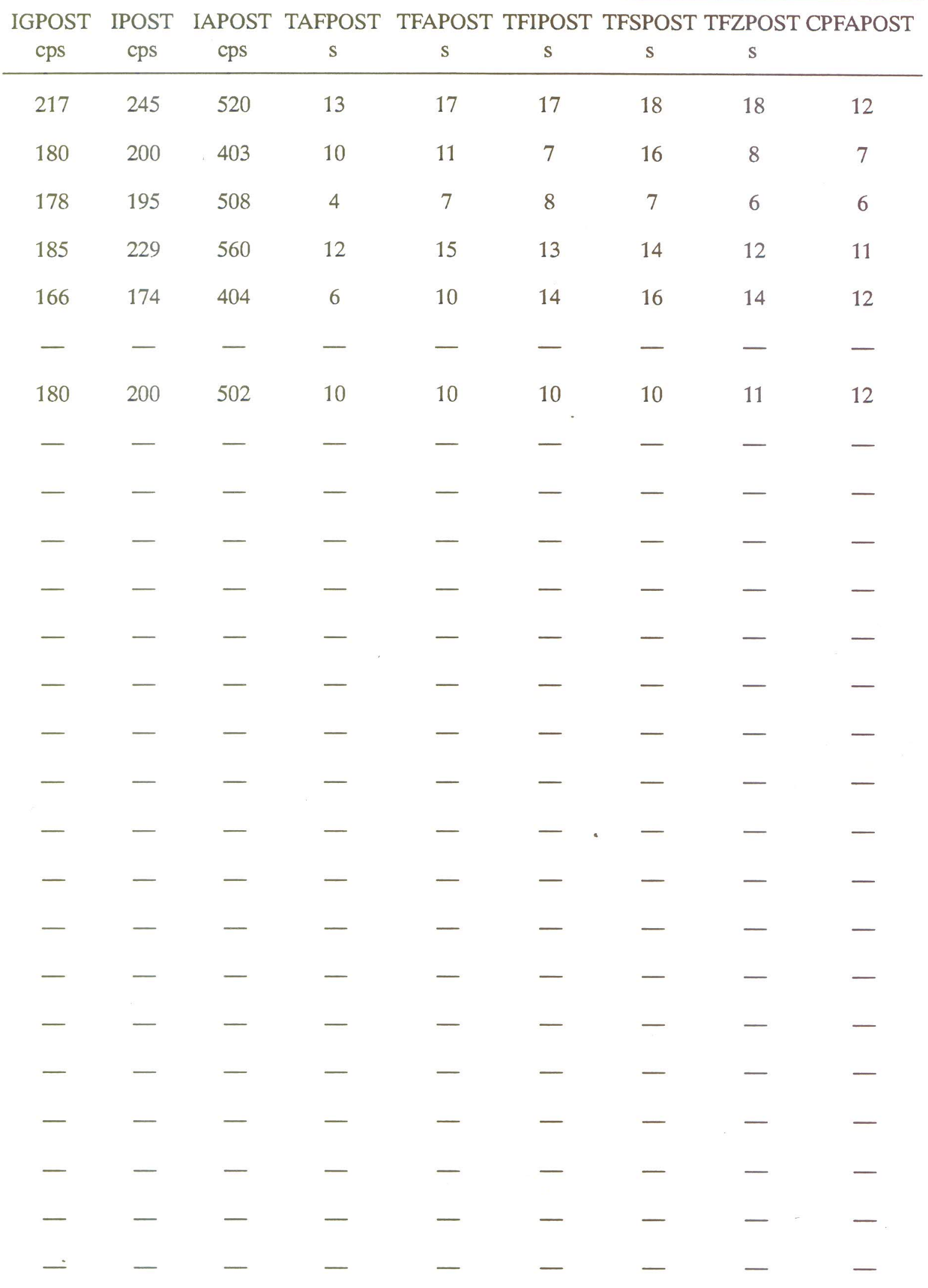




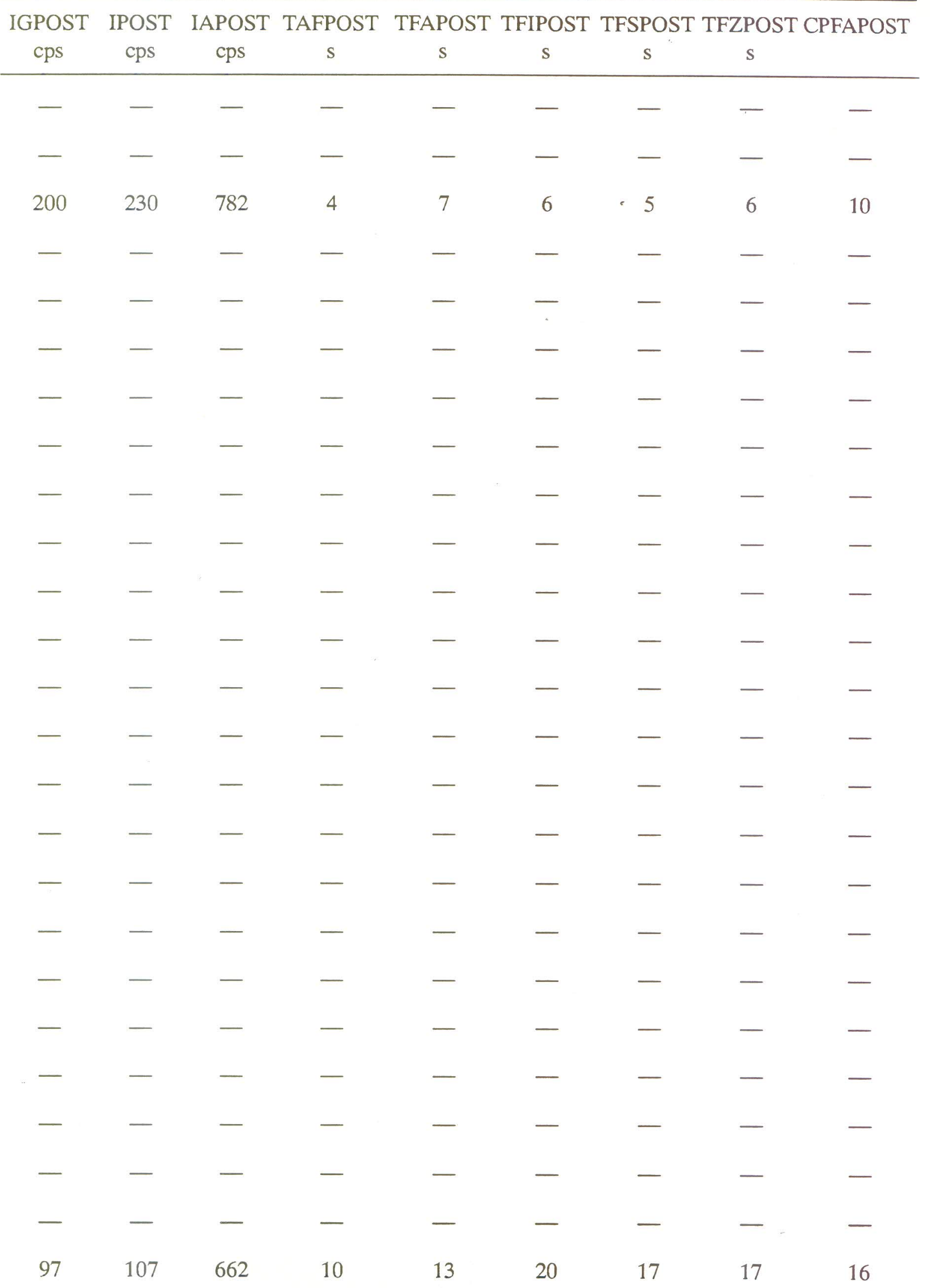

